\title{
EMOCIONES, JUSTICIA Y DERECHOS HUMANOS
}

\author{
UNIVERSIDAD NACIONAL DE LA PLATA
}

Ciencias Jurídicas y Sociales - Maestría en Derechos Humanos

Directora de tesis

María Julia Bertomeu

Alumna

Erica Baum

LA PLATA, BUENOS AIRES, ARGENTINA

Febrero de 2011 



\section{Sumario}

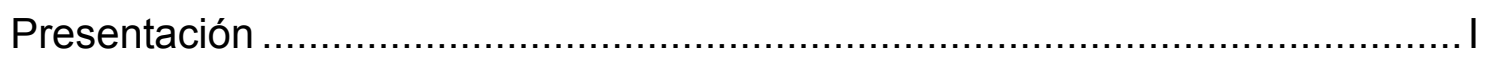

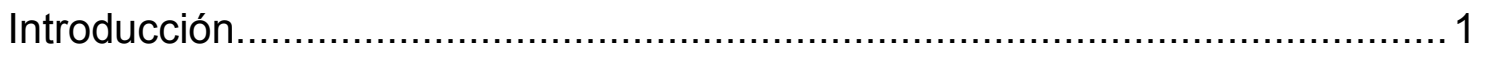

PARTE PRIMERA Investigación y Desarrollo .................................................... 7

Sección I: Estado de la Cuestión ............................................................. 9

1. ¿Qué entendemos por emociones morales? .............................. 9

2. El rol de las emociones morales en la esfera pública.....................19

3. Emociones según el modelo de punición: .........................................30

Sección II: Marco Teórico de la Investigación .....................................................77

La Teoría Neo-Estoica de las Emociones de Martha C. Nussbaum ..................77

Emociones y Derechos Humanos ................................................................. 86

PARTE SEGUNDA Aplicación del Marco Teórico............................................ 89

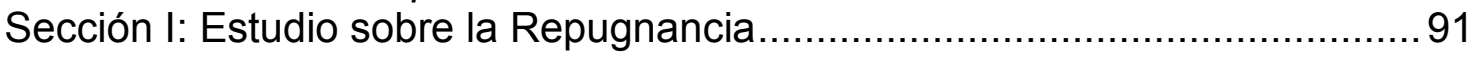

1. Introducción y nociones..............................................................91

2. Repugnancia en la esfera pública ………................................... 95

3. "Crímenes Repugnantes" ........................................................ 99

4. Repugnancia, justicia criminal y derechos humanos..................... 102

Sección II: Análisis de la Sentencia .......................................................... 115

1. Presentación de la sentencia elegida...................................... 115

2. Aniquilación y Limpieza ideológica.........................................116

3. Emociones en los relatos de víctimas, victimario y testigos ......... 122

4. Sentimientos morales de los jueces en el veredicto....................... 134

Conclusiones: Emociones, Justicia y Derechos Humanos .............................. 141

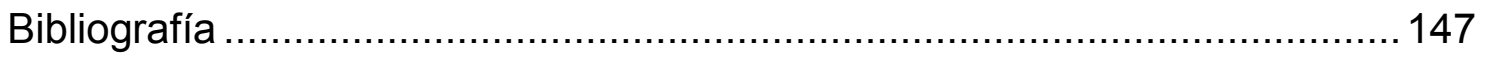





\section{Presentación}

Este trabajo ha implicado para mí un compromiso ético y social. Intento aproximar una nueva visión sobre algo que está latente pero que no ha sido explorado acabadamente en el área de las ciencias jurídicas y sociales. Ese "algo" resultan ser nuestras emociones morales tal como se expresan en la justicia. Algunas emociones, como expondré, nos develan una parte de nuestro ser que nos torna vulnerables, que hace que percibamos al mundo como incierto e inseguro. Sostendré que las emociones, al interactuar con los pensamientos, operan como una chispa de "consciencia" de lo que para cada persona es percibido como bueno o malo para sí ante una determinada situación vital y es por ello que dan cuenta de un punto de vista moral; razón que justifica el análisis de ésta investigación y su pertinencia para introducir esta perspectiva ética-normativa en el fuero judicial, a efectos de arribar a juicios más justos al momento de decidir sobre derechos humanos lesionados.

El objetivo de esta investigación consistirá en indagar sobre la influencia recíproca entre emociones y racionalidad; idea que será trasladada a la esfera del poder público judicial para investigar qué lugar juegan efectivamente las emociones morales allí, especialmente en la justicia en lo criminal, y qué limite establecen a dicha relación los principios éticos de igual valor y dignidad humana, autonomía personal y respeto por la diversidad cultural, en que se fundan los derechos humanos. La cuestión a elucidar será: ¿deben ser tenidas en cuenta las emociones en los actos de justicia decisorios? Mi respuesta será -siguiendo la teoría de de las emociones de Martha Nussbaum que he escogido como marco teórico para esta investigación- que las emociones expresadas en la justicia, siempre que se pongan en dialogo con el respeto de los principios éticos de los derechos humanos, deben ser tenidas en cuenta porque aportan un contenido cognitivo y evaluativo que resulta beneficioso para un análisis 
cabal de los hechos, y hacen visible el pleno ejercicio del derecho de participación en la justicia.

La investigación se centrará en examinar cómo se reflejan en los actos de justicia decisorios las emociones morales expresadas por los testigos y las partes de un proceso judicial; en desentrañar qué rol desempeñan los eventuales sentimientos morales manifestados por las personas encargadas juzgar dentro de los textos de las sentencias que resuelven sobre condenas o absoluciones; y en evaluar si la consideración de las emociones en la justicia afecta el principio ético de imparcialidad. Desarrollaré este punto en relación con mi hipótesis de trabajo, que es la siguiente: Si un ser humano que está afligido por una situación de vulnerabilidad, propia o ajena, logra expresar sus emociones en un proceso judicial, entonces habrá ejercido su derecho de expresión acabadamente, y, si la persona encargada de juzgar logra reflejar dichas emociones morales en el acto de justicia decisorio, entonces habrá fallado teniendo en cuenta todos los aspectos humanos que involucra la situación a resolver. Sin embargo, para que pueda lograrse un incremento progresivo de expresión de emociones morales en la justicia y de captación y consideración de las mismas en los actos de justicia decisorios, también es preciso el respeto de los principios éticos que dan sustento a los derechos humanos, así como contar con una teoría normativa de las emociones morales.

Para llevar a cabo esta tarea, he ordenado metodológicamente la exposición de la investigación en dos partes. La parte primera contiene dos secciones, una referida al estado de la cuestión y otra al marco teórico. En la parte segunda estudiaré el contenido cognitivo-evaluativo de la repugnancia, una emoción muy controvertida en la esfera pública y privada, y aplicaré dicho marco al caso seleccionado.

En el estado de la cuestión exploraré qué entendemos por emociones morales; analizaré el rol que las mismas desempeñan en la esfera pública, en el derecho y en la justicia; revisaré la discusión, histórica y actual, sobre la relación entre un esquema punición retributivo "vengativo" y su conexión con emociones morales vindicativas, tales como la ira, la revancha y el odio; y 
estudiaré la expresión de emociones bajo un esquema distinto de punción: la justicia social restaurativa, que se centra en prácticas judiciales que buscan establecer un clima de diálogo y participación activa de todas las partes directa e indirectamente implicadas en el proceso que les permita arrepentirse, perdonar y la reconciliarse.

El marco teórico escogido seguirá algunas ideas básicas desarrolladas por la filósofa norteamericana Martha C. Nussbaum, quien ha realizado un trabajo pionero en torno al valor cognitivo de las emociones morales, incluso en relación con la justicia y la lesión de derechos humanos. La autora ha invertido el tradicional enfoque filosófico del "amor por la sabiduría" por el de "la sabiduría del amor" y en su libro Upheavals of Thought. The Intelligence of Emotions (2001) desarrolló una teoría neo-estoica sobre la racionalidad de las emociones morales. La autora afirma que:

"Si las emociones están acompañadas por inteligencia y discernimiento, y si contienen en si mismas una conciencia de lo que es valioso o importante, entonces no pueden ser apartadas fácilmente del juicio ético, como tan a menudo lo han sido en la historia de la filosofía."1

Es propósito de esta investigación realizar una exploración analítica del estado de la cuestión sobre el tema; describir e interpretar la teoría general de la racionalidad de emociones morales de Martha Nussbaum; revisar críticamente el rol que la repugnancia tiene en la justicia criminal y aplicar el marco teórico elegido a la sentencia en la que resultó condenado Miguel Ángel Etchecolatz, "por delitos de lesa humanidad, cometidos en el marco del genocidio que tuvo lugar en la República Argentina entre los años 1976 y 1983". 2 La aplicación del marco teórico la llevaré a cabo mediante la interpretación analítica, y puesta en diálogo entre los principios éticos de justicia y respeto por los derechos humanos y la expresión de emociones extraídas de los relatos de testigos, víctimas y victimario que quedaron plasmadas en la sentencia, por una parte, y la consideración de tales principios de justicia y de respeto por los derechos humanos y los sentimientos morales

\footnotetext{
1 Martha Craven Nussbaum, (2001), Upheavals of Thought. The Intelligence of Emotions, Cambridge: Cambridge

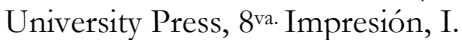

2 Texto literal, tomado de la parte resolutiva del fallo que se analizará en la Parte Segunda de ésta investigación.
} 
expresados en el veredicto por las personas encargadas de juzgar, por la otra. 


\section{Introducción}

Los conflictos humanos que llegan a la justicia poseen un componente emocional irreductible: sentimos ira ante el daño, temor ante una amenaza y vergüenza ante una humillación. Por otro lado, las emociones morales se distinguen de las emociones básicas que experimentan otras especies animales no humanas por su contenido evaluativo y cognitivo. Interactúan con la razón, revelándonos el estado de vulnerabilidad que nos es inherente. Hay una larguísima discusión filosófica sobre el papel de la ira en la vida pública por ejemplo la interesante discusión de Séneca con Aristóteles- y el tema es muy controvertido también en el ámbito de la justicia en general y de la justicia criminal en particular, porque se asocian ciertas emociones con un esquema de punición retributivo y "vengativo".

El problema central de esta investigación consistirá en indagar si es posible afirmar, como lo hacen diversos autores, que las emociones morales tienen un contenido cognitivo-evaluativo que las torna racionales y conductoras de estructuras normativas, y si contribuyen a explicar y valorar los casos que llegan a la justicia. Específicamente, tal problema podría formularse de la siguiente manera: ¿Bajo qué marco teórico sería posible sortear la tensión existente entre un ideal de justicia vinculado a una idea retributiva de la pena, asociada a pasiones vindicativas, y un ideal de justicia que, al mismo tiempo que considere y refleje en los actos de justicia decisorios las emociones morales expresadas por las partes y testigos en los procesos judiciales, sea respetuoso de los principios éticos en los que se fundan los derechos humanos? La cuestión es crucial, puesto que he de referirme fundamentalmente a emociones vindicativas o reactivas como la revancha, la repugnancia y la ira en la vida pública y especialmente en la justicia, y porque muchos autores, incluida Martha Nussbaum, rechazan la pertinencia de la 
repugnancia para el ámbito público por considerar que su uso lesiona el principio de dignidad humana.

El enfoque que adopto para el desarrollo de la investigación se enmarcará en una concepción liberal del derecho. Es por ello que asumiré idealmente el funcionamiento de una sociedad democrática, pluralista e inclusiva; cuyos miembros se reconocen como iguales; se han confiado mutuamente el respeto de todos y cada uno de ellos por su libertad individual y diversidad cultural, y han acordado protegerse mutuamente de las afrentas a su dignidad humana mediante el establecimiento de normas coercitivas que sancionen a quien la autoridad judicial -con un poder delegado republicanamente- adjudique responsabilidad por lesionar derechos humanos. Suponiendo también que todas las partes comprometidas en un proceso judicial habrán de tener la posibilidad de participar en el mismo, expresando sus emociones cabalmente, las que serán justamente consideradas constituyendo la esfera pública judicial una garantía social para el dialogo pacífico y respetuoso.

Dentro de ese esquema, la justicia como institución pública será considerada poseedora de un poder soberano delegado para hacer valer efectivamente el ideal de justicia consensuado por toda la sociedad y fundado en el sentido de justicia que mujeres y hombres nos pre-comprometimos a cultivar. En consecuencia, intentaré analizar el rol que cumplen las emociones morales en la justicia teniendo en cuenta estas tres dimensiones. La primera, inherente a los seres humanos, se relaciona con el sentido de justicia que Aristóteles definió como virtud completa "en relación con el otro", lo que alude al carácter intersubjetivo de la de la misma. ${ }^{3}$ La siguiente, relativa a la justicia como principio, ya no individual sino social, puesto que queremos que nuestra sociedad sea justa, que todas y todos tengamos iguales oportunidades para desarrollar el ejercicio de la libertad individual, que el reparto de bienes y servicios sea equitativo y que quienes atenten contra la sociedad y/o la dignidad humana de sus individuos respondan justamente por sus actos. La tercera dimensión se refiere a la práctica de justicia intersubjetiva e

\footnotetext{
${ }^{3}$ Aristóteles, Ética Nicomaquea, Buenos Aires: Colihue, 2007, V, 1129 b.
} 
institucional, dada por la interacción de los individuos con el poder judicial, que como foro público de expresión de razones y emociones morales garantizará el justo reconocimiento de los derechos humanos lesionados.

Advertimos que la justicia es la primera virtud de las instituciones sociales, así como la verdad lo es de los sistemas del pensamiento, tal como lo recordara John Rawls en su obra Teoría de la Justicia (1971). En términos generales podemos afirmar, junto con Rawls, que: “...la justicia de un esquema social depende esencialmente de cómo se asignan los derechos y deberes fundamentales, y de las oportunidades económicas y las condiciones sociales en los diversos sectores de la sociedad...". Es evidente entonces que en una sociedad que valora el ejercicio pleno de la libertad individual y el respeto por la diversidad cultural, y en la que el diseño e implementación de las políticas públicas permite el reparto equitativo de bienes y servicios, los individuos son capaces de desarrollar un "sentido de justicia", que es indispensable para lograr la cohesión social.

Pero dicho sentido de justicia, al ser una virtud, debe ser cultivado para poder ser ejercido en relación con otros seres humanos. Muchas de las catástrofes y crímenes aberrantes contra la humanidad podrían dejar de producirse si se le diera a la justicia, por medio del aprendizaje de la misma, el valor que humanamente tiene. ¿Cuál es tal valor? Como bien decía Aristóteles, la justicia es una virtud completa, porque no se agota en si misma sino que se refina por medio de las relaciones interpersonales, puesto que ser justa o justo nos permite tener una "visión completa" de los hechos, circunstancias o eventos que nos relacionan con otras personas.

De este modo el sentido de justicia tiene una dimensión social, además de tener una dimensión individual e intersubjetiva, que adquiere junto con los sentimientos y emociones que la acompañan. Es así como John Stuart Mill otorgaba un lugar preponderante al estado emocional y a las emociones en sí, como generadores de una vida feliz y socialmente solidaria, así decía: "Los principales factores de una vida satisfactoria resultan ser dos, cualquiera de los

\footnotetext{
${ }^{4}$ John Rawls, Teoría de Justicia, traducción de María Dolores González, 2da. Ed., México, FCE, 1995, 6ta. Reimpresión, 2006, p. 21.
} 
cuales puede ser suficiente para tal fin: la tranquilidad y la emoción". 5 Para Mill, el deseo de "castigar" a alguien que había hecho un daño era uno de los elementos de su teoría de la justicia que se encontraba estrechamente vinculado con dos sentimientos "naturales" que lo generaban de modo espontáneo: "el impulso de auto-defensa" y la "simpatía". 6

Recordemos que Mill otorgaba valor intrínseco a la espontaneidad, como contenido de la libertad para el desarrollo individual, y al cultivo del fortalecimiento de la consciencia para sobreponerla a los "deseos ardientes", en miras a poder elegir libremente. ${ }^{7}$ Según Mill:

"Cada persona, cuanto más desarrolla su individualidad, más valiosa se hace a sus propios ojos $y$, en consecuencia, más valiosa se hará a los ojos de los demás... los límites impuestos a su egoísmo facilitan un superior desarrollo de la parte social de su naturaleza. Atenerse a las rígidas reglas de la justicia en beneficio de los demás desarrolla los sentimientos y las facultades que tienen por objeto el bien de los otros".

Proponía John S. Mill que la simpatía, como sentimiento, era un modo solidario "vital" de preocupación por otros seres humanos, no tan sólo por los que nos rodean habitualmente, sino por todos los seres humanos:

“...las personas justas rechazan los daños causados a la sociedad, aún cuando ellas no resulten de modo alguno lesionadas, y no rechazan un daño que se les cause a ellas personalmente, por penoso que sea, a menos que sea de un tipo cuya represión interese tanto a la sociedad como a ellas particularmente...".

Su principio de solidaridad vincula emociones naturales y espontáneas con el sentimiento de justicia y la generosidad hacia aquellos miembros de la sociedad que son víctimas de daños. Entonces, resaltaré el aporte efectuado por Mill en términos de solidaridad social, como principio esencial de una sociedad justa, y el reconocimiento incipiente que efectuó sobre las emociones calmas y simpáticas como base de la justicia social; pero, como veremos en extenso en el desarrollo de esta investigación, dejaré de lado la concepción del castigo y su búsqueda "instintiva" de venganza como elementos básicos de una

\footnotetext{
${ }^{5}$ John Stuart Mill, El Utilitarismo. Un sistema de la Lógica, Libro VI, Capitulo XII, Madrid: Alianza Editorial, 2 da. Reimpresión, 2007, p. 60.

${ }^{6}$ Mill, J., obra citada, p. 118.

7 Ver John Stuart Mill, (1859), Ensayo sobre la Libertad, traducción de María Ángeles Navillo, Madrid: Mestas, Proyectos Anáforas, 2006, pp. 98-125.

${ }^{8}$ Mill, J., Ensayo..., obra citada, p. 107-108.

${ }_{9}^{9}$ Mill, J., El Utilitarismo..., p. 120.
} 
teoría de la justicia, por estimar que dicha noción de "castigo" y toda su connotación semántica, y la idea de retribución vengativa, resultan inapropiadas como base para el igual respeto de los derechos humanos de las partes en la justicia. 



\section{PARTE PRIMERA}

Investigación y Desarrollo 



\section{Sección I: Estado de la Cuestión}

\section{1. ¿Qué entendemos por emociones morales?}

Mi preocupación inicial consistirá, muy brevemente y a manera de introducción, en dilucidar ¿qué entendemos por emociones? y ¿cuándo nos encontramos ante emociones con contenido moral? Es evidente que los resultados de distintas ciencias tales como la antropología, la biología, la filosofía y la medicina, entre otras, nos advierten de una constante evolución del concepto de emoción en general y del concepto de emoción moral, en particular, y también sobre el papel que juegan y que deberían jugar en la vida del ser humano tanto a nivel individual como social.

Según la concepción que se adopte, las emociones pueden ser consideradas como simples corrientes eléctricas que se manifiestan corporalmente; como impulsos impensados o fuerzas energéticas que se contraponen; o, por el contrario, como un modo de juicio normativo en relación con un objeto que contiene un punto de vista interior sobre la realidad de la persona que experimenta la emoción, una percepción de sí misma y de su relación con el mundo y, también, una creencia acerca de lo que ese objeto representa para ella. Asimismo, las "emociones morales" pueden ser consideradas tanto la causa o puerta de acceso para la moral como el efecto o consecuencia directa de la realización de una acción con contenido moral, sea este contenido positivo o negativo desde el punto de vista moral. Estos temas son muy interesantes y controvertidos, como habremos de ver a lo largo de esta investigación.

Los filósofos antiguos, griegos y romanos, prestaron cuidadosa atención al tema de la prosperidad del ser humano -a la que denominaban la felicidad- y realizaron un estudio profundo acerca del sufrimiento humano y de las emociones y pasiones, a las que se aproximaron desde distintas concepciones, 
muchas veces contrapuestas.

La escuela helenística, en sus tres corrientes principales que son el epicureísmo, el escepticismo y el estoicismo, intentó curar el sufrimiento humano extirpando las emociones como un proceso de sanación del alma o de generación del florecimiento humano o de la eudaimonía. ${ }^{10}$ Como expresaba Martha C. Nussbaum, en su interesantísimo y original libro La Terapia del Deseo (1994), estoicos y epicúreos aconsejaron: “...en la mayoría de los casos, extirpar las emociones de la vida humana... como un estado de libertad frente a la turbación y la agitación, sobre todo reduciendo los compromisos del agente con los objetos inestables del mundo...".11

Esta perspectiva marcó una diferencia clara con la filosofía griega prehelenista que, por teorizar en el mundo más estable de la polis, buscaba cambiar de consuno al mundo y al yo de acuerdo a un ideal exigente de felicidad del ser humano y de la ciudadanía. Estoicos y epicúreos filosofaron en un mundo mucho menos estable -el de la cosmópolis- difícil, si no imposible, de cambiar mediante la deliberación de quienes conformaban una ciudadanía libre. Y, si no era posible cambiar al mundo desde la deliberación sobre los actos externos, entonces era preciso trabajar sobre la propia psicología de cada individuo para evitar la frustración en un mundo inestable. Un ejemplo claro de ello, lo encontramos en los Diálogos de Lucio T. Séneca quien, separándose en este punto de la filosofía aristotélica, le aconsejaba a Sereno, en su texto sobre "La Tranquilidad del alma", que:

“...en las circunstancias políticas poco propicias habría que procurar reivindicar más tiempo para el ocio y las letras, y dirigirse sin tardanza al puerto, como si de una peligrosa travesía se tratara; no esperar a que la situación te deje libre sino alejarte tú mismo de ella...". 12

\footnotetext{
10 "Eudaimonía" es mucho más que un estado o sentimiento, implica una actividad por parte del agente, en contraposición al simple estado de felicidad. Aquí hay acuerdo con la filosofía aristotélica, pues Aristóteles definió a la felicidad como "una actividad del alma acorde con la virtud".

11 Marta C. Nussbaum, 1994, La Terapia del Deseo, Teoría y práctica en la ética helenística, traducción de Miguel Candel, Barcelona: Paidós Ibérica, 2003, pp. 66-67. Expresa Nussbaum que los filósofos antiguos articularon una concepción ético normativa sobre las emociones que comprende un análisis de las mismas, un procedimiento para la erradicación de las creencias que contienen y causan aflicción a la vida humana y una finalidad ética consistente en un compromiso, que a su juicio, condiciona los argumentos en que se basan.

12 Séneca, Lucio Anneo, Diálogos, Barcelona: Altaya, 1997, según la edición anterior de Tecnos 1986, p. 290. Conviene recordar que el ocio significaba, en la tradición griega, la posibilidad de deliberar que era propia del
} 
Profundizaré sobre el enfoque aportado por la escuela de la filosofía helenística al describir y analizar el marco teórico de esta investigación, puesto que sobre aquél se asienta en parte la teoría neo-estoica de las emociones de Martha Nussbaum. Pero, volviendo ahora sobre la cuestión que ocupa este apartado "¿qué son las emociones? y, especialmente, ¿qué entendemos por emociones morales?", las respuestas dependerán de adoptar una perspectiva teórica cognitivista o no cognitivista.

Hay dos perspectivas distintas sobre la naturaleza de las emociones en general. Una de ellas, la no cognitivista, considera a las emociones como meros cambios fisiológicos sin contenido conceptual ni complejidad alguna. La otra perspectiva, la cognitivista, entiende que las emociones contienen una sabiduría ínsita que las explica y que está compuesta por un objeto de conocimiento al cual ellas se dirigen, y por creencias y apreciaciones formuladas sobre dicho objeto. Las teorías cognitivistas conciben a las emociones como estados mentales intencionales y perceptuales asociados con el pensamiento.

Hay distintas teorías cognitivistas pero, por lo general, todas ellas niegan que las emociones sean puro afecto, meras sensaciones, cambios fisiológicos o respuestas biológicas percibidas en los centros motores cerebrales, porque suponen que las emociones involucran algún tipo de juicio de valor. En éste último sentido, hallamos los aportes teóricos de Robert C. Solomon en The Passions (1976) y de Martha C. Nussbaum en Upheavals of Thought. The Intelligence of Emotions (2001).

Las teorías cognitivistas abrevan en la teoría de las virtudes y los afectos de Aristóteles, para quien las emociones cumplían un rol relevante tanto en la psicología individual como en la vida social. ${ }^{13}$ Como veremos más adelante, el aporte más significativo de Aristóteles en relación con las emociones humanas ha sido -y es- haber concebido que el contenido normativo de las mismas era importante y que debía ser tenido en cuenta a la hora de juzgar acciones, tanto

hombre libre. Quien está consumido por la actividad -los trabajos que consumen casi toda la vida de un hombre y que, además, lo hacen depender de otros-carece de esa posibilidad.

${ }^{13}$ Las principales obras de Aristóteles que abordan las emociones morales y se pueden consultar son Retórica, Ética Nicomaquea y Política. 
individuales como colectivas.

Las teorías cognitivistas contemporáneas también admiten que las emociones, en sí mismas, portan una cierta clase de juicio de valor y cognición. John Deigh, por ejemplo, distingue dos modelos dentro de este enfoque teórico: un modelo "estándar" que hunde raíces en la teoría de las pasiones desarrollada por los filósofos griegos y romanos, quienes básicamente identificaron a las emociones con las creencias, los juicios de valor y las decisiones; y otro modelo, que Deigh denomina "perceptual", que sostiene que la evaluación cognitiva que contienen las emociones no implica un juicio de valor de la clase de una afirmación de una proposición, sino de una percepción. $^{14}$

Las diferentes teorías sobre las emociones no son nuevas. Es sabido que, en su clásica disertación titulada What is an Emotion?, ${ }^{15}$ William James se cuestionó si en el proceso cerebral emocional sólo intervenía el centro motor sensorial o si implicaba algún proceso peculiar de percepción. Para ello distinguió entre las emociones ordinarias, cuya manifestación se procesa en la corteza cerebral mediante un mecanismo de asimilación que es percibido exteriormente por los sentidos a través del cuerpo, y las emociones morales, que también denominó intelectuales o estéticas, cuyo modo de producción y percepción es puramente cerebral e implican un proceso de cognición. En este sentido, James sostuvo que en las emociones morales nuestra condición mental está aliada a una evaluación sobre lo correcto o incorrecto, que implica una advertencia sobre la verdad, que en si misma constituye un acto cognitivo; añadiendo que la diferencia entre ambas emociones yace en la ausencia (o silencio) de expresión corporal que hay en las segundas. Sin embargo, para él, en ambas emociones opera un proceso de alteración de una condición orgánica (interna -la idea que excita la emoción en el cerebro- causa una perturbación mental o interna y externa -la idea que excitó la emoción y su manifestación corporal ocasionan un disturbio corporal) en los centros de percepción de los cambios que hay en las porciones de corteza cerebral que, al

\footnotetext{
14 John Deigh, "Concepts of Emotions in Modern Philosophy and Psychology", en Oxford Handbook of Philosophy of Emotion, de Peter Goldie, Oxford: Oxford University Press, 2010, capítulo I.

15 William James, “What is an Emotion?” Mind, Vol. 9, No. 34 (Abril, 1884), pp. 188-205.
} 
combinarse con consciencia, transforman un simple objeto de aprehensión en un objeto de sentimiento emocional.

La hipótesis de partida de James consistió en sostener que los cambios corporales son consecuencia directa de la "percepción de un hecho excitante" y que "nuestros sentimientos sobre esos cambios ocurridos son las emociones". ${ }^{16}$

En síntesis, hay según James una relación entre las sensaciones y las emociones, pero estas últimas suponen un proceso de percepción distinto y también procesos cognitivos. Es importante tener en cuenta que, según su teoría, las emociones morales no motivan el comportamiento, ni constituyen una fuerza que impele a la acción, sino que simplemente dan cuenta del fenómeno que las ocasiona. ${ }^{17}$

Me detendré a analizar brevemente las teorías cognitivistas de las emociones, que constituyen el marco teórico de la presente investigación.

En su ensayo "Emotions and Choice" de 1973, Robert Solomon, uno de los filósofos anglosajones que más ha influido en el cognitivismo, sostuvo que las emociones son: “...racionales y deliberadas más que irracionales $y$ disruptivas, son muy parecidas a las acciones, elegimos una emoción tal como elegimos un curso de acción...." 18

Para Solomon, en efecto, las emociones tienen un "contenido intencional", son "acerca de" un objeto emocional al cual se dirigen o, lo que es lo mismo, siempre remiten a un objeto intencionado. $Y$ además, según el autor, las emociones se eligen; lo cual significa que son voluntarias, producto de un proceso de reflexión, porque nadie elige sin reflexionar.

El autor trazó una línea demarcatoria entre las emociones y los estados

\footnotetext{
16 James, W., obra citada, PP. 189-190.

17 Para revisar aportes recientes, que retoman la tesis de Williams James véanse, por ejemplo, a Antonio R. Damasio, en El error de Descartes: la emoción, la razón y el cerebro bumano (1994), traducción castellana de Joandomènec Ros, Buenos Aires: Paidós (Drakontos Bolsillo), 2010 y a Jesse Prinz, en "Emotions Embodied", penúltimo capítulo en Thinking about Feeling, de Robert Solomon, Oxford: Oxford University Press, 2003.

18 Robert C. Solomon, "Emotions and Choice", Explaining Emotions, Amelié Oksenberg Rorty. Los Ángeles: University California Press, 1980, pp. 251-252.
} 
de ánimo tales como euforia, melancolía y depresión, que no hacen referencia a un objeto específico, o que pueda especificarse de manera clara, afirmando que las emociones tienen dos componentes integrados: la sensación y el objeto emocional; objeto éste que versa sobre una creencia "acerca de algo", y no sobre una referencia a un hecho concreto e independiente de la creencia como se podría suponer. El autor se encargó de aclarar que esta afirmación, sin embargo, no implica que las emociones sean la creencia, sino que “...comparten una propiedad importante de las creencias...". 19

\title{
Lo que Robert Solomon quiso indicar es que somos emocionalmente
} responsables porque las emociones son claramente activas, elegidas, y no son algo que nos "pasa" o nos torna pasivos. En concreto, sostuvo que al dar cuenta de aquello "acerca" de lo cual sentimos una determinada emoción, respondemos por nuestro estado emocional y este es, a todas luces, un proceso racional para Solomon, quien agregó que:

\begin{abstract}
"Las emociones típicamente involucran sensaciones. Quizás esencialmente involucren sensaciones. Pero las sensaciones nunca son suficientes para diferenciarse o identificarse con una emoción, y la emoción nunca es simplemente una sensación, ni siquiera una sensación nada más. Por otra parte, es claro que uno puede tener una emoción sin sensación alguna. Uno puede estar enojado sin sensaciones de enojo: uno puede estar enojado por tres días o cinco años y no sentir nada identificable como sensación de enojo...." 20
\end{abstract}

Solomon y varios cognitivistas ubican a las emociones más cerca de las acciones que de las pasiones o patrones de comportamiento. Como dice el propio Solomon:

“...las emociones no son ocurrencias, por lo tanto no pueden ser causadas... La causa de una emoción está en función de cierta clase de explicación. La causa debe distinguirse en cada caso de aquello "acerca" de lo que la emoción es (de su objeto). La causa es siempre un episodio actual... el objeto de mi emoción es siempre un objeto intencional. La causa está sujeta a cierta clase de generalización normativa en un sentido en que el objeto de la emoción no lo está...". ${ }^{21}$

Si la emoción fuera el simple efecto de una causa y no la respuesta a un objeto intencionado y representando como tal por el sujeto que la experimenta,

\footnotetext{
${ }^{19}$ Solomon, R., "Emotions and Choice", obra citada, p. 253.

${ }^{20}$ Solomon, R., obra citada, p. 254.

${ }^{21}$ Ibíd., p. 256.
} 
entonces no habría lugar para creencias e intenciones y el conflicto emocional sería explicable como un evento biológico sin más, en el que el sujeto, sus creencias y motivos no tendrían papel alguno. $\mathrm{Y}$, entre otras cosas, eso supondría que no somos responsables por nuestras emociones puesto que no las hemos elegido libremente en función de creencias y motivos personales.

En síntesis, para Solomon, las emociones son juicios de valor afectivos y normativos "acerca” de algo: “...tener una emoción es sostener un juicio de valor sobre una situación personal...". 22 Y, añade que:

"Si las emociones son evaluaciones y pueden ser "disparadas" (y también instigadas) por consideraciones de otros juicios de valor, es claro que nuestras emociones son en cierto sentido nuestra factoría, $y$ que somos responsables por ellas... Dado que los juicios normativos pueden ser cambiados a través de influencias, argumentos, y evidencias, $y$ dado que puedo influenciar, provocar argumentos $y$ buscar evidencias, soy tan responsable por mis emociones como por los juicios que hago. Mis emociones son los juicios que formulo... son juicios temerarios, algo que hago, pero precipitadamente. ${ }^{23}$

Contra la posición de quienes esgrimen que los juicios de valor son el producto de una reflexión más o menos calma, para argumentar que las emociones son irracionales y que, por esa misma razón, es necesario eliminarlas de la vida pública; Solomon aduce que las emociones son juicios normativos precipitados e inmediatos y que su carácter temerario no obsta para su racionalidad.

Según el autor, hay dos tipos de juicios normativos: aquellos que formula un ser humano sobre la emoción de otro y el juicio que consiste en juzgar la propia emoción, pero, en ambos casos:

"...los juicios normativos que involucran las emociones son inseparables de... nuestros motivos, creencias e intenciones... el hecho que las emociones aparezcan como un comportamiento "fuera de lugar" no es consecuencia de que las emociones sean irracionales, pero es consecuencia natural del hecho que las emociones son respuestas a situaciones inusuales ante las cuales un patrón de comportamiento parece ser inapropiado...". ${ }^{24}$

Si bien, como afirma Solomon, las emociones pueden no responder a un

\footnotetext{
22 Ibíd., p. 258.

${ }^{23}$ Ibíd., p. 261-263.

24 Ibíd., 264.
} 
comportamiento "previsible", eso no es consecuencia de su carácter irracional, sino de situaciones especialmente intensas que nos alteran y, por tanto, dan lugar juicios de valor sobre una situación que sí se percibe como "irracional", porque resulta extraña y digna de expresión emotiva. Bajo este enfoque teórico, las emociones pueden dar cuenta de las razones que se tuvieron para reaccionar de un modo determinado, pero también pueden explicar y brindar respuesta sobre los hechos y el contexto que las rodean de un modo que no son capaces de hacerlo los simples argumentos. Como hemos de ver, este es un tema muy importante para esta investigación.

Solomon ha refutado también las críticas de algunos antropólogos a las teorías cognitivistas de las emociones, consistentes en demostrar que las sociedades primitivas las reprimieron por considerarlas irracionales. Su explicación es la siguiente:

“...las sociedades que consideran tabú al comportamiento emocional -lo condenan en los hombres y lo rebajan en las mujeres- ...aplauden el comportamiento "cool", que naturalmente requiere de estrategias que son similarmente "cool". En dichas sociedades, el comportamiento emocional aparece como irracional porque es una pésima estrategia, no porque no sea deliberado...". ${ }^{25}$

La objeción de Solomon, a la supuesta irracionalidad de las emociones alegada por los antropólogos, apunta a hacer una distinción clara entre lo que puede ser considerado irracional desde un punto de vista primitivo o evolutivo por ejemplo, manifestar emociones que pueden ponernos en peligro- y el concepto filosófico de irracionalidad. Si podemos explicar el surgimiento de una emoción conociendo, al menos, las creencias e intenciones de un sujeto, entonces será posible entenderlas racionalmente e incluso tenerlas muy en cuenta como señal importante de acontecimientos relevantes para la vida pública. Y si esto es así, también será posible argumentar sobre si las creencias que sustentan tales emociones son correctas o incorrectas o si las intenciones que subyacen a las mismas son adecuadas o inadecuadas.

\footnotetext{
${ }^{25}$ Ibíd., p. 266. Dicha posición tabú encuentra, a mi criterio, raigambre en la histórica desigualdad entre hombres y mujeres, que sostuvo y fomentó patrones sociales opresivos tales como censurar la expresión de emociones en los hombres y denigrar a las mujeres que así lo hacían, como si las emociones fueran algo que había que ocultar o reprimir. Este tipo de promoción de enfriamiento en los vínculos también fue analizado por Martha Nussbaum, como veremos más adelante, como un comportamiento que genera una falta de sensibilidad ante la vulnerabilidad y fragilidad entre los seres humanos.
} 
Es importante lo que destacaba Solomon sobre la intencionalidad de las emociones. Dicha intencionalidad, según el autor, consiste en que todas ellas "versan sobre un objeto", aunque en el momento en que se experimenta la emoción la persona no pueda reconocer su intención, en virtud de la urgencia e intensidad propias de las mismas:

“...lo que distingue una emoción de otros juicios de valor, es el hecho de que una emoción nunca puede ser deliberada y cuidadosamente considerada. Las emociones son esencialmente elecciones no deliberativas... en este sentido son, en efecto, "ciegas" y miopes; una emoción no puede verse a sí misma...". ${ }^{26}$

Antes de concluir con la exposición de uno de los representantes más conspicuos del cognitivismo contemporáneo, recordaré algunas críticas que se han realizado a quienes consideran que las emociones son simplemente estados afectivos sin contenido cognitivo. ${ }^{27}$

Como dice John Deigh en "Cognitivism in the Theory of Emotions" el enfoque centrado en el estado afectivo de las emociones recibió dos críticas principales por parte de los teóricos cognitivistas: una que indica que omiten algo fundamental, que es incluir la noción de intencionalidad propia de acciones y estados mentales $y$, la otra, que objeta que al haber asimilado a las emociones con meras sensaciones corporales, los no cognitivistas no son capaces de explicar por qué una misma emoción puede ser, en determinadas circunstancias, irrazonable o irracional y en otro momento ser razonable o racional. ${ }^{28}$ Es claro, por ejemplo, que si fueran meras sensaciones no tendría sentido afirmar que alguien no se debería haber enojado en una circunstancia $X$, o que el miedo de $A$ fue injustificado, o que una persona debería avergonzarse de lo que hizo. Todo ello supone que es posible argumentar sobre las emociones y realizar juicios normativos sobre las mismas, afirmar que han sido desmedidas o irracionales, etc.

Por consiguiente, es innegable que las emociones son algo más que una

\footnotetext{
${ }^{26}$ Ibíd., p. 270.

27 Aquí situamos las posiciones de John Locke, en An Essay Concerning Human Understanding (1695) y de David Hume, en $A$ Treatise of Human Nature (1739), ambos influidos por la concepción de las emociones, definidas como excitaciones que provienen del alma, formulada por René Descartes en The Passions of the Soul (1649).

${ }^{28}$ Deigh, J., (1994), "Cognitivism in the Theory of Emotions", Emotions, Values, and the Law, Oxford: Oxford University Press, 2008, pp. 39-71.
} 
sensación o un movimiento corporal intempestivo e irracional, aunque también, y para decirlo con Nussbaum, es preciso ponerlas en diálogo constante con el respeto de los principios éticos. En primer lugar, porque una emoción siempre hace referencia a algo que es el objeto de dicha respuesta emocional: el miedo o la esperanza sólo tienen sentido si hay un objeto que los provoca y en cierto modo, la verdadera identidad de mi miedo como tal depende de que tenga un objeto referencial, ya que si el objeto del temor desaparece simplemente quedaría en el cuerpo un temblor o palpitaciones. En segundo lugar, ese objeto es un objeto intencional, lo cual significa que está interpretado por la persona que experimenta tal emoción. Es una percepción del objeto propia de la persona, que puede ser adecuada o no. $\mathrm{Y}$ esta es una característica que también sirve para identificar a las distintas emociones, por ejemplo, el objeto del miedo consiste en percibir a una situación o persona como una amenaza sobre la propia. En tercer lugar, las emociones no sólo son modos de interpretar un objeto sino que también contienen creencias sobre ese objeto o suceso, y muchas veces esas creencias son complejas. Por ejemplo, cuando siento furia hay una serie de creencias complejas en juego: que una persona me ha dañado, que el daño no es trivial, que lo hizo intencionalmente, que sería correcto que quien perpetró el daño reciba un castigo, etc. $\mathrm{Si}$, por ejemplo, compruebo que el daño no fue intencional o que la persona no fue la que me dañó, entonces sería irracional seguir sosteniendo la misma emoción. ${ }^{29}$

De lo expuesto hasta ahora podemos observar que, si bien hay distintas teorías sobre las emociones, hay teorías cognitivistas plausibles que son capaces de explicar que las emociones morales resultan algo más que fuerzas impensadas o simples sensaciones corporales. Es importante comprender y transmitir el valor que las emociones morales aportan -junto con las razonesen la vida de los seres humanos, puesto que con su contenido cognitivo y evaluativo contribuyen positivamente en la toma de decisiones morales, pero también, como veremos a continuación, al ponerlas en diálogo con los principios éticos que sustentan los derechos humanos cumplen un rol en los procesos de deliberación y creación de normas jurídicas de una sociedad; lo

\footnotetext{
29 Martha Nussbaum, "Emotions as Judgments of Value and Importance", en Thinking about Feeling, Contemporary Philosophers on Emotions, de Solomon, Robert (edit), Oxford: Oxford University Press, 2004, pp. 187 ss.
} 
cual ameritará su justa consideración al momento de elaborar sentencias judiciales.

\section{El rol de las emociones morales en la esfera pública}

El tema de esta investigación tiene que ver con el papel que juegan las emociones morales en la esfera pública $y$, especialmente, en la justicia. Intentaré demostrar en este punto qué relevancia ética y social tiene la inclusión normativa de las emociones morales en las instituciones públicas como el poder judicial. Mi hipótesis es que las emociones morales son "conductoras de estructuras normativas" imprescindibles para el derecho, siempre que en su creación se hayan respetado los principios éticos de autonomía personal, igual valor y dignidad humana y respeto por la diversidad cultural en los que se fundan los derechos humanos.

Una primera aproximación acerca del rol que desempeñan las emociones morales en la esfera pública fue aportada por Aristóteles, en Retórica, al ocuparse de los "discursos persuasivos" y entimemas que se empleaban en los juicios y asambleas públicas. ${ }^{30}$ En este texto, Aristóteles trata el tema de los discursos persuasivos, entendidos como una forma de razonamiento respecto de un hecho controvertido sobre el que se delibera, y dice algo que resulta interesante para introducirnos en este tema:

"El asistente a la Asamblea y el juez deciden en el momento acerca de cuestiones presentes y concretas, a las que con frecuencia vienen asociados el afecto, el odio y el interés personal, de suerte que ya no están en condiciones suficientes para considerar la verdad, sino que [también] empañan su decisión con su propio agrado o desagrado.,31

Pero Aristóteles no se limitó a constatar un hecho innegable -que las emociones como el afecto y el odio están presentes en las deliberaciones- sino que también ofreció una teoría normativa de las emociones: su célebre doctrina del justo medio, que será desarrollada más adelante en relación con la ira y con la justicia correctiva.

La relevancia de las emociones morales en la vida individual y social ya

\footnotetext{
30 Sobre el uso de entimemas en el discurso jurídico, específicamente en la presentación de pruebas, véase: Luis Vega Reñón, “Entimemas”, en DOXA, Cuadernos de Filosofía del Derecho, 27, 2004, pp. 283-315.

31 Aristóteles, Retórica, Buenos Aires: Gradfíco, 2007, I, 1, 1354b.
} 
se encontraba delineada desde tiempos ancestrales por Aristóteles, quien sostuvo que:

“...como la retórica pretende que se llegue a una decisión... es necesario que no sólo se atienda a que el argumento sea convincente y fidedigno, sino (es necesario también) ponerse a si mismo y al juez en una determinada posición... porque los que aprecian no valoran las cosas del mismo modo que los que odian, ni los que están furiosos de la misma manera que los que están tranquilos...". 32

En síntesis: amor, odio, furia y tranquilidad son emociones humanas que tienen cabida y se expresan en las instituciones, de modo que será preciso tratar de entender que gravitan en la comprensión de los hechos particulares sobre los que públicamente se delibera, aportando "argumentos emocionales", junto con los argumentos racionales, para la toma de decisiones.

Martha Nussbaum abreva en la tradición aristotélica y helenista de las emociones. En "El discernimiento de la percepción: una concepción aristotélica de la racionalidad pública y privada", ${ }^{33}$ en efecto, calificó de "sutil y persuasiva" la concepción sobre la deliberación descripta porque, a su entender, Aristóteles fue capaz de captar la "complejidad absoluta" y "dificultad angustiosa" que representa para los seres humanos elegir el bien.

En efecto, según Nussbaum, de la tesis aristotélica se desprende que la capacidad de percibir lo heterogéneo nos revela la perplejidad y el estado de vulnerabilidad que es inherente a la naturaleza humana:

"La buena deliberación es como la improvisación teatral o musical, donde lo que cuenta es la flexibilidad, la sensibilidad y la apertura al exterior; apoyarse en un algoritmo no sólo es insuficiente, es un indicio de inmadurez y debilidad... La comprensión práctica es como la percepción en el sentido de que es no inferencial, no deductiva; es una habilidad para reconocer los rasgos más relevantes de una situación compleja. 34

Y es en este contexto, en el cual Nussbaum rescata la teoría aristotélica de la deliberación frente a las teorías morales kantianas o utilitaristas, clásicas y modernas que, a su entender, les niegan un rol a las emociones y a las

\footnotetext{
32 Obra citada, II, 1, 1378a.

33 Martha C. Nussbaum, (1990), "El discernimiento de la percepción: una concepción aristotélica de la racionalidad pública y privada”, en El conocimiento del amor. Ensayos sobre filosofía y literatura, traducción de Rocío Orsi Portalo y Juana María Inarejos Ortíz, Libros, Madrid: Antonio Machado, 2005, pp. 113-201.

${ }^{34}$ Nussbaum, M., obra citada, pp. 147-148.
} 
fantasías como componentes de las deliberaciones, por considerarlas egoístas y autocomplacientes. ${ }^{35}$ Nussbaum indica que la teoría aristotélica ubicó a las emociones en un lugar preponderante de la vida humana, por cuanto:

“...la persona verdaderamente buena no sólo actuará bien sino que además sentirá las emociones apropiadas ante aquello que elige. La motivación correcta y los sentimientos motivacionales no son los únicos componentes de la virtud o del bien de esa persona, también lo son la reacción correcta y los sentimientos con los que reacciona....36

En consecuencia, y de acuerdo con la concepción aristotélica, las emociones morales forman parte del proceso de deliberación individual dando cuenta de su naturaleza mixta ya que en ellas participan el intelecto y la pasión.

Conforme expresa Nussbaum en el texto que estoy analizando, las emociones morales pueden ser interpretadas como las perspectivas de cada ser humano sensible que nos aportan información valiosa acerca del conocimiento o reconocimiento perceptivo ético de lo que para cada quien es verdadero, poniendo de manifiesto su compromiso con el mundo.

Toda la teoría sobre el rol de las emociones en la deliberación individual desarrollada por Aristóteles, es también aplicable a la vida pública. Para decirlo con Nussbaum:

"La vida humana buena es una vida con y hacia los otros; ser miembro de la polis es una parte esencial de las actividades de uno mismo que se dirigen a los demás... Los hombres atenienses no reservaban la expresión del amor, el sufrimiento y la ira para el ámbito privado del hogar. La esfera pública estaba teñida de interés público. ${ }^{, 37}$

En síntesis, las emociones morales desempeñan un papel destacable no sólo para la toma de decisiones en la vida individual sino también para las deliberaciones públicas. Es por esa razón que, siguiendo la línea teórica abierta por Nussbaum sobre el rol de las emociones en la vida pública, he considerado interesante evaluar la viabilidad de su propuesta para analizar las emociones morales expresadas por las partes y testigos que fueron reflejadas en la sentencia condenatoria de Etchecolatz. La elección de este caso se debe a que ha sido uno de los primeros en resolverse -dentro de los juicios seguidos por

\footnotetext{
35 Ibíd., p. 150-151.

36 Ibíd., p. 154.

37 Ibíd., p. 189.
} 
flagrantes violaciones a los derechos humanos cometidos durante la última dictadura militar en Argentina-, y ha tenido una gran repercusión institucional.

En el punto siguiente, intentaré demostrar que al ser contempladas en la elaboración de normas jurídicas las emociones morales podrían cumplir tres funciones básicas: de reconocimiento de la igualdad ética, protección de la dignidad humana y respeto por los derechos humanos.

\title{
2.1. El rol de las emociones morales en el derecho:
}

En una entrevista realizada por la revista Reason, Marta Nussbaum afirmaba lo siguiente:

\begin{abstract}
"No considero que sea correcto decir que las emociones no pertenecen a la razón pública. Las emociones no son impulsos gratuitos, son un modo de deliberar sobre asuntos de importancia. La ira, por ejemplo, es una forma de reflexionar sobre el daño; no es posible definir o distinguir una emoción de otras emociones negativas sin hacer referencia a ese tipo de reflexión. Algunas emociones son esenciales para el derecho y para los principios públicos de justicia: la ira ante las acciones incorrectas, el miedo frente a nuestra seguridad, la compasión frente al dolor de los otros, todas ellas son razones para hacer leyes que protejan los derechos de las personas. Por supuesto que algunas manifestaciones particulares de ira, miedo y compasión pueden ser inoportunas, pero cuando resisten un escrutinio deben ser tenidas en cuenta y la ley tiene que darles cabida.,38
\end{abstract}

Nuevamente Nussbaum plantea una interesante conexión entre emociones y razones y específicamente entre emociones y razones públicas, esto es, entre aquellas emociones morales como la ira, el temor o la compasión, que pueden ser expuestas públicamente como resultado de una deliberación práctica. Es muy instructivo el recorte que ella hace respecto de dichas emociones, como "esenciales para el derecho", o sea, del papel que las mismas juegan como "razones" para elaborar normas de protección de derechos humanos.

Por otro lado, las emociones morales se modelan a partir de una idea de vulnerabilidad del ser humano, que permite comprender los vínculos emocionales que lo conectan con otros seres de su misma especie. En su obra El Ocultamiento de lo Humano (2004), Nussbaum sostuvo que: “...la falta de

\footnotetext{
38 Emociones humanas y vida política. Entrevista a Martha Nussbaum. Traducción castellana de María Julia Bertomeu en: http://www.sinpermiso.info/textos/index.php?id=582
} 
comprensión de la fraternidad en las relaciones humanas implica una perversión dañina de lo social, puesto que quienes se sitúan por encima de las vicisitudes de la vida establecen vínculos jerárquicos que causan o infligen daño a los congéneres. ${ }^{39}$ Coincido con la autora en que la negación del aspecto humano emocional podría resultar en una negación de la igualdad ética, exponiéndonos a los seres humanos a una situación de mayor vulnerabilidad.

A partir de tales afirmaciones Nussbaum sostiene que el derecho en general y las leyes penales en particular apelan el estado emocional de los seres humanos para proteger su posible vulnerabilidad frente al daño, recordando en este punto la idea de John Stuart Mill, quien afirmó que toda la estructura del derecho penal se basa en "típicas situaciones ante las cuáles sentimos ira o temor". Según la autora, la importancia de las emociones en el derecho sólo es pensable si se acepta una tesis central: que las emociones morales tienen un componente cognitivo-evaluativo, constituido por el conocimiento del objeto al que se dirigen y por una apreciación subjetiva; porque permiten arrojar luz tanto sobre las creencias fácticas como sobre los juicios de valor formulados sobre dicho objeto de conocimiento.

Como hemos visto antes, la autora explica que las creencias fácticas $y$ los juicios de valor en los que la emoción se funda pueden ser verdaderos o falsos y razonables o irrazonables, entendiendo aquí por razonable o irrazonable, en relación con las normas jurídicas, al "hombre medio" u "hombre razonable". ${ }^{40}$ Pero Nussbaum también recuerda acertadamente que algunas normas fundadas en prototipos de comportamiento humano resultan inaplicables cuando son analizadas en términos de emociones morales porque:

“...la historia de nuestra vida tiene incorporados el conflicto y la ambivalencia. No es sorprendente que concibamos maneras de negar nuestra mortalidad y animalidad humana, ni que nuestras emociones reflejen estos conflictos... El hombre medio, que es además un ser humano, exhibe mucha tensión, ambivalencia $y$, en términos normativos, falta de razonabilidad...". ${ }^{41}$

\footnotetext{
39 Martha Nussbaum, (2004), El Ocultamiento de lo Humano, Vergüenza, Repugnancia y Ley, traducido por Gabriel Zadunaisky, Buenos Aires: Katz, 2006, p. 20.

${ }^{40}$ Nussbaum, M., El Ocultamiento de lo Humano, obra citada, p. 46-52.

${ }^{41}$ Ibíd., p. 51. Creo necesario recordar aquí que en los ordenamientos jurídicos encontramos frecuentemente
} 
Ahora bien, tratar de demostrar que las normas que regulan el orden jurídico de una sociedad tienen y deben tener en cuenta el componente emocional no es una tarea sencilla, entre otras cosas porque quienes están acostumbrados a razonar sobre asuntos de interés público suelen creer que para que las leyes sean aplicables tienen que estar fundadas sólo en la razón y nunca en las pasiones.

Intento demostrar, contra dicha postura, que las normas jurídicas tienen un contenido emocional, implícito o explicito, y que puesto en diálogo con los principios éticos que fundan a los derechos humanos ese contenido puede brindarnos protección contra las amenazas a nuestra dignidad humana; contra los ultrajes a nuestra integridad física, sexual, psíquica, emocional y espiritual; contra las afrentas a nuestra libertad individual $y$, finalmente, contra los atentados a la vida. Si todos estos bienes, no fueran relevantes para cada ser humano y para las sociedades que nos vinculan, estaríamos expuestos a un mayor y más intenso estado de violencia que el que actualmente padecemos. $Y$ lo mismo sucedería si en su estructura las normas jurídicas que protegen los derechos humanos no hubieran previsto una protección ante la violencia que podría resultar a partir de emociones negativas tales como el odio, la ira, la revancha, los celos, la envidia, la enemistad, la vergüenza, la humillación, la repugnancia y la indignación.

Pero dichas normas jurídicas no sólo nos protegen de ese tipo de violencia, sino que también apelan a emociones positivas al buscar restaurar el equilibrio emocional perdido cuando, por ejemplo, intentan reestablecer la dignidad humana menoscabada, o instan a las autoridades administrativas y judiciales a tratar a las víctimas con compasión. ${ }^{42}$

Es sabido, por ejemplo, que el odio racial, étnico o religioso ha sido, y

\footnotetext{
normas basadas en lo que se ha denominado como: un "buen padre de familia", un "buen hombre de negocios" y otro tipo de etiquetas normativas que suelen emplearse, y que por cierto excluyen a media humanidad por no considerar a las mujeres en su terminología. Pero la discriminación en el lenguaje jurídico, en razón del género, si bien es un tema delicado y relevante, traspasa el propósito de ésta investigación.

${ }^{42}$ Tal es el caso, por ejemplo de la "Declaración sobre los principios fundamentales de justicia para las víctimas de delitos y abusos de poder", dictada por la Asamblea General de las Naciones Unidas (AG 40/34), el 29 de noviembre de 1985, en su $96^{a}$ período de sesiones, que en el punto 4 de su Anexo de exige a los estados partes que las autoridades que mantengan trato con víctimas de delitos, lo hagan atendiendo un criterio ético de compasión y respeto por su dignidad humana.
} 
es, el motor de atroces crímenes contra la humanidad, es por ello que los derechos humanos buscan resguardar la dignidad humana de las afrentas producidas, en parte, por el odio que forma parte de la naturaleza humana; sin embargo es preciso contar una teoría normativa que nos permita comprender cuál es el contenido cognitivo-evaluativo del odio al momento de juzgar las acciones, y esa consideración puede ayudar a una correcta aplicación de tales normas.

Es así como podemos vislumbrar que las normas jurídicas de protección de derechos también están construidas sobre la base de emociones morales típicas que pueden llegar a experimentar los seres humanos, y que muchas de ellas pueden derivar en hechos de violencia que, a su vez, afectan a un aspecto importante de aquella persona o grupo de personas a la que la acción violenta se podría dirigir, cual es su dignidad humana.

En síntesis, las normas jurídicas que protegen la dignidad humana, además de preveer hipotéticamente cuáles son las situaciones conflictivas que nos exponen a un mayor sufrimiento, aquellas que provocan tanto en quien las padece como en el resto de la sociedad una profunda pena y dolor existencial, registran en su construcción las áreas de vulnerabilidad humana que podrían resultar afectadas por un hecho particular ultrajante. $Y$ esa vulnerabilidad, que es inherente a los seres humanos, también está constituida por las emociones morales, por aquello que realmente causa aflicción en un individuo, grupo o sociedad y que requiere de la intervención judicial para el reconocimiento de derechos lesionados.

\subsection{El rol de las emociones morales en la justicia:}

Ahora bien, ¿qué papel juegan las emociones morales en la justicia como institución pública? $\mathrm{Y}$, si las emociones juegan un papel importante en el momento de la creación de normas jurídicas, ¿por qué habrían de ser apartadas al momento hacerse cumplir tales normas a través del poder público judicial?

Como ya dije al inicio de esta primera parte, la justicia en tanto esfera de un poder público delegado soberanamente actúa como último eslabón de control dentro de la sociedad, para evitar el avasallamiento de derechos 
humanos, sancionar la impunidad y pacificar los conflictos. La hipótesis que pretendo probar es que cuando en los procesos judiciales se toma en cuenta la expresión de emociones morales que manifiestan todas las partes y testigos, es altamente probable que eso redunde en beneficio del efectivo reconocimiento de los derechos humanos.

Dado que por lo general se piensa lo contrario, que la ausencia de emociones en la justicia garantiza la imparcialidad en el juicio, trataré de mostrar que esta segunda hipótesis está errada, porque consiste en asimilar la expresión de emociones con una concepción retributiva de la pena, y que esta equiparación es falsa, al menos cuando las emociones morales son puestas en diálogo con los principios éticos de autonomía personal, igual valor y dignidad humana y respeto por la diversidad cultural en los que se fundan los derechos humanos.

En un artículo publicado en el año 2002, en la revista británica Sage, Susanne Karstedt explicaba cómo:

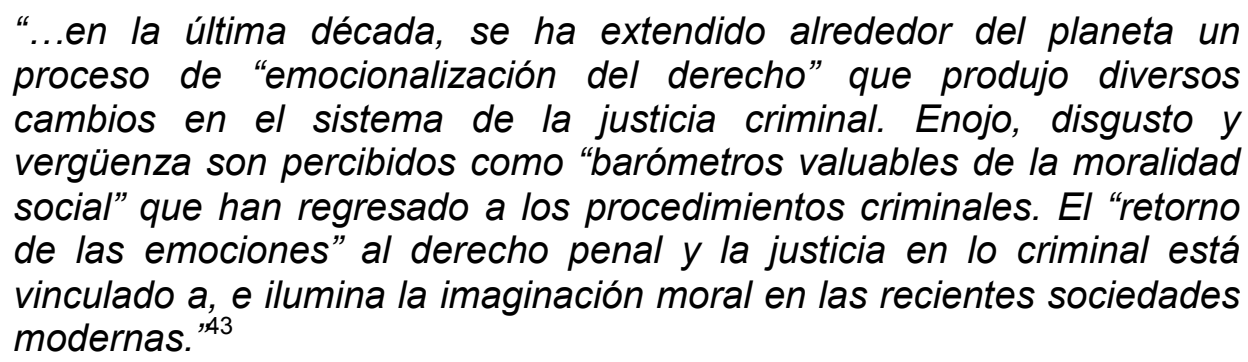

La autora ponía de manifiesto que las emociones morales han penetrado en los sistemas de justicia penal mediante las expresiones de enojo y ultraje de víctimas y testigos, y de vergüenza y remordimiento de las personas perpetradoras, y que tales emociones se manifiestan en las salas de las Cortes y despiertan en las autoridades judiciales y en la sociedad sentimientos de simpatía o compasión. Dice la autora: “...las instituciones legales, y en particular el sistema de justicia criminal, han sido designadas para lidiar con la mayor parte de las emociones intensas y con los conflictos emocionales, con las emociones individuales pero también con las colectivas..." 44 Como

\footnotetext{
43 Susanne Karstedt, "Emotions and Criminal Justice", en Sage Publications, London, Thousand Oaks and New Delhi: 2002, Vol. 6 (3), p. 299-317.

${ }^{44}$ Karstedt, S., obra citada, p. 300.
} 
recuerda Karstedt, ese retorno de las emociones a la esfera pública de la justicia en lo criminal se dio en dos ámbitos relevantes: en el discurso público acerca del crimen y en las emociones en que se basan los modos de punición en la justicia en lo criminal. ${ }^{45}$

La autora considera que ambas facetas se retroalimentan mutuamente y generan nuevas cuestiones a elucidar, y que tienen que ver: 1) con el lugar que ocupan las emociones, tradicionalmente ignoradas en la justicia criminal; 2) con la relación de las emociones con los principios morales; y 3) con saber distinguir entre el impacto social emocional y la expresión de emociones auténticas en la justicia.

La constatación de Karstedt es interesante e incontestable. La autora atribuye el retorno de las emociones al derecho y la justicia en lo penal a los cambios transculturales que atraviesan las sociedades modernas, especialmente por medio de la imaginación moral que despiertan los medios de comunicación masivos a través del "espectáculo" del crimen. En tal sentido, Karstedt sostiene que las políticas criminales se basan en la expresión de emociones colectivas de temor y enojo ante el crimen, esto es, en patrones sociales de reacción emocional y no en emociones básicas. $Y$ añade que dichas emociones colectivas reactivas suelen también ser captadas por distintas organizaciones sociales para llevar a cabo sus objetivos y tareas. La crítica que formula la autora a la intervención de los medios de comunicación masivos en las expresiones colectivas de emociones es que al cambiar constantemente el foco del objeto emocional en el público "espectador", hacen que las emociones de compasión o enojo, por ejemplo, sean volátiles.

Esto último, me lleva ahora a considerar si las emociones morales desempeñan un rol instrumental o constitutivo dentro de la justicia y en particular dentro de la justicia en lo criminal.

Susan Karstedt se ocupó de analizar este tema bajo tres esquemas teóricos: uno funcional, que considera que las emociones se encuentran en función de los principios morales y, como la vergüenza, cumplen el rol de

45 Ibíd., p. 301. 
disuadir a las personas de trasgredir normas morales y legales; otro constitutivo, que sostiene que la acción contiene la emoción moral y por lo tanto la emoción provee la motivación para el cumplimiento de las normas éticas; y un tercer esquema indicativo, según el cual la relación entre emociones y moralidad está dada por el compromiso de las propias acciones frente a otras personas conforme con los principios éticos que se han aceptado. Bajo esta última concepción, los sentimientos morales no motivan la acción moral pero están ligados a los principios y juicios éticos que efectivamente las indican. Este es el punto de vista que asume la autora, quien afirma:

“...una teoría contemporánea de las emociones claramente refuta la noción de que los principios morales y la construcción normativa están erigidas sobre sentimientos básicos y universales, y que éstos constituyen tales principios. En lugar de ello, los principios y axiomas de justicia y equidad definen el asunto y despiertan nuestros sentimientos morales. Consecuentemente, las emociones como enojo, repugnancia y vergüenza son indicadores de nuestras creencias y convicciones, pero no las constituyen..." 46

El último interrogante que aborda Karstedt se relaciona con la "visibilidad" de auténticas emociones en la justicia y su distinción con la provocación de emociones, otro aspecto relevante para esta investigación. Los procesos regulatorios que prevén la expresión de emociones, como es el caso de la justicia social restaurativa que pone en dialogo la expresión de emociones de personas víctimas y victimarias, son una parte importante para el desarrollo de prácticas emocionales compartidas en la justicia según la autora, ya que operan controlando e inhibiendo la manifestación de emociones reactivas dentro de un espacio público. La autora afirma que la institución judicial brinda el contexto en el cual se puede visibilizar una diversidad de componentes emocionales, aunque sugiere que incluso en tales contextos es preciso indagar sobre la autenticidad de las emociones traídas al juicio, cosa que comparto plenamente.

Quien también se ocupó de razonar sobre el valor instrumental o intrínseco de las emociones en el discurso de la justicia en lo criminal es el profesor australiano Arie Freiberg, en su ensayo "Affective vs. Effective Justice:

\footnotetext{
46 Ibíd., p. 311.
} 
Instrumentalism and emotionalism in criminal justice". ${ }^{47} \mathrm{El}$ autor sostiene que no hay un solo foco de conflicto que resolver para dilucidar esta cuestión, sino varios: 1) el pronunciamiento judicial en las sentencias, entendido como fuerza de autoridad; 2) la simbología arquitectónica de las cortes, como símbolo de poder; y 3) las reuniones de audiencias con las víctimas en las cortes y el público alrededor el tribunal, como símbolo de comando y control en las que se reafirma el orden y se reasegura la calma en un pretendido clima de "discreción". Según Freiberg en todo ese proceso "hay una gama de emociones proyectadas" y, en tal sentido, el éxito de una política pública para la prevención del crimen radica más en saber captar la imaginación del público que en pretender controlar el delito. ${ }^{48}$ Para el autor si bien en muchas ocasiones las opiniones públicas son diversas y pluralistas, los gobiernos por el contrario establecen políticas que desoyen dicha variedad; siendo que la punición del crimen es responsabilidad de todos y cada uno de los miembros de una sociedad. $Y$ bien recuerda el autor al analizar la complejidad del asunto que la responsabilidad es social y que el poder sancionatorio es delegado, ya que yace en la soberanía popular y se expresa de modo diverso.

En un trabajo reciente, "The Limits to Evidence-Based Policy: Evidence, Emotion and Criminal Justice" (2010), Freiberg examina las prácticas tradicionales de recolección de evidencias en las se fundan las políticas públicas para probar "racionalmente" hechos y sostiene que se tratan sólo de una parte del proceso, puesto que para que el proceso criminal resulte exitoso hay que tener también en cuenta las argumentaciones afectivas que cumplen un papel legítimo en el discurso público de la justicia. ${ }^{49}$ En apoyo de su argumento sostiene que las políticas públicas tradicionales sobre colección de evidencias resultan inadecuadas en tres sentidos:

"Primero, simplemente hay muchas evidencias de limitaciones en torno a la racionalidad de las operaciones en la práctica para que aceptemos su integridad teórica, salvo como un inalcanzable, e incluso indeseable, ideal. Segundo, y más importante, los supuestos que subyacen en la noción de toma de decisiones racionales... son cuestionables.

\footnotetext{
47 Arie Freiberg, (2001), "Affective vs. Effective Justice: Instrumentalism and Emotionalism in Criminal Justice", Punishment and Society, pp. $265-278$.

${ }^{48}$ Freiberg, A., "Affective vs...., obra citada.

49 A. Freiberg y W. G. Carson, (2010), "The Limits to Evidence-Based Policy: Evidence, Emotion and Criminal Justice", The Australian Journal of Public Administration, vol. 69, no. 2, pp. 152-164.
} 
Sabemos que hay limitaciones de habilidades y conocimientos en quienes toman las decisiones, que las personas o instituciones raramente tienen claridad... que las decisiones suelen ser institucionales más que individuales y simbólicas más que fundamentales... Tercero,... hay otros factores en torno a las emociones y afectos que podrían potencialmente ser tan o más significativos aún, persuasivos o convincentes en la formulación de políticas públicas..." ${ }^{50}$

Es interesante el planteo que muestra los límites de las políticas públicas tradicionales y por qué el autor adopta una postura cognitivista sobre las emociones y sostiene que los debates relacionados con el aborto, los crímenes de guerra, la fertilización asistida, el control de armas y las acciones afirmativas, entre otros tantos temas de interés social, pueden ser comprendidos y formulados en los proyectos de las políticas públicas si se tienen en cuenta a las emociones "como parte de un proceso de reflexión y no como su antítesis". 51

El tema explorado en este punto, resulta importante para pensar en un diseño no meramente consecuencialista de políticas públicas para la prevención del crimen, que prevea los aspectos humanos emocionales que subyacen en las problemáticas delictivas, sin caer en un populismo penal ni servir para complacer pasiones vindicativas, para lo cual tendrán que ponerse en dialogo con los principios éticos de autonomía personal, igual valor y dignidad humana y respeto por la diversidad cultural, para contribuir al igual respeto de los derechos humanos de todas las partes comprometidas en un asunto judicial. En el punto que sigue me ocuparé de las emociones morales vindicativas tales como la ira, la revancha o el odio bajo dos esquemas distintos de punición en la justicia: retribución y restauración.

\section{Emociones según el modelo de punición:}

En principio me concentraré en las emociones morales vindicativas que históricamente han tenido un lugar en la justicia; las emociones que buscan "satisfacer un deseo de venganza" y que son canalizadas en los procesos judiciales mediante expresiones de ira, odio o resentimiento por parte de las víctimas; o bien aquellas pasiones que aparecen ante un asunto judicial de

\footnotetext{
50 A. Freiberg y W. G. Carson, (2010), “The Limits to Evidence..., obra citada, p. 156.

51 Obra citada, p. 157.
} 
gravedad institucional y se instauran como un clamor colectivo de "castigo" y "encierro" a quienes hayan perpetrado crímenes aberrantes, impactando en los medios de comunicación masiva y pretendiendo influir en las decisiones judiciales. Para llevar a cabo esta tarea indagaré sobre el origen de la venganza en la justicia, y su relación directa con la ira. Luego de ello, exploraré la preponderancia que las acciones de arrepentimiento, perdón y reconciliación han adquirido en la actualidad en el ámbito judicial, mediante la implementación de prácticas sociales restaurativas que aportan a las partes y testigos un espacio público para la auténtica expresión de sus emociones en los procesos judiciales con el objetivo de restaurar los vínculos afectados y reestablecer la confianza y dignidad humana menoscabada. En este punto mencionaré algunas experiencias internacionales de justicia social restaurativa, como por ejemplo la instauración de Comisiones por la Verdad y la Reconciliación para el enjuiciamiento a los responsables de graves violaciones a los derechos humanos. Observaré y analizaré ambas ideas: la de punición retributiva y la de justicia social restaurativa, en perspectiva con el respeto igualitario de los derechos humanos de las personas víctimas y victimarias.

\subsection{Emociones vindicativas y justicia retributiva:}

En lo que sigue revisaré el origen de la justicia retributiva y describiré cómo la misma se encuentra vinculada con acciones individuales o colectivas vengativas. El objetivo de esta breve indagación preliminar consistirá en descubrir y explicar qué emociones morales subyacen tras la idea de venganza y cómo son transferidas a la justicia. La investigación versará sobre el análisis de la venganza asociada con una idea retributiva de la pena, que tiene por objeto castigar a todas las personas con un mismo patrón y en igual proporción a la gravedad del daño causado, dejando de lado el histórico debate teórico, jurídico-filosófico, sobre la justificación social de la pena. ${ }^{52}$

\subsubsection{Origen del retribucionismo "vengativo":}

La idea de justicia asociada a lo que se ha dado en llamar el "retribucionismo vengativo", encuentra su origen en el "Antiguo Testamento"

\footnotetext{
52 Sobre el cual se puede ver Los límites de la responsabilidad Penal: Una teoría liberal del delito, de Carlos Santiago Nino, Buenos Aires: Astrea, 1980, pp. 197-268.
} 
cuando refiere:

"Y éstas son las leyes que les expondrás... El que hiriere a un hombre de modo que muera, será muerto irremisiblemente. ...Cuando alguno hiriere a su siervo o a su sierva con palo de modo que muera bajo su mano, (el muerto) será vengado irremisiblemente... Cuando riñeren hombres y dieren un golpe a una mujer preñada, de modo que abortare,... si resultare desgracia, darás vida por vida, ojo por ojo, diente por diente, mano por mano, pie por pie, quemadura por quemadura, herida por herida, chichón por chichón." (Éxodo, XXI, 12, 20 y $23-25) .{ }^{53}$

En el mismo texto se dice también: "Y habló el Señor a Mo-shé, diciendo: ...de manera que el que matare a una bestia hará restitución; más el que matare a un hombre, será muerto." (Levítico, XXIV, 21). ${ }^{54} \mathrm{Y}$ también proclama: “...Y no aceptaréis rescate por la vida del homicida que es reo de muerte; sino que será muerto irremisiblemente." (Números, XXXV, 31). ${ }^{55}$

Si bien tanto la acción vindicativa como los sentimientos de odio y rencor se encuentran expresamente prohibidos en el mismo texto bíblico, cuando dice: "No vengarás, ni guardarás rencor contra los hijos de tu pueblo; sino que amarás a tu prójimo como a ti mismo. Yo soy el Señor." (Levítico, XIX, 17 y 18), ${ }^{56}$ los pasajes mencionados precedentemente aluden claramente a tomar venganza en casos de atentados a la vida de personas sometidas a esclavitud; de aplicar pena de muerte, sin posibilidad de "rescate" en los casos de homicidio; de restitución en los supuestos de matanza de animales; y de retribución en la exacta medida del daño causado en los casos de homicidios y lesiones a la integridad física. ${ }^{57}$

\footnotetext{
${ }^{53}$ Versión castellana de La Biblia traducida por León Dujovne y Manasés Konstantynowsky con correcciones de Moisés Konstantynowski, Ediciones Sigal, Buenos Aires, 1982, pp. 123-125.

${ }^{54}$ La Biblia, obra citada, p. 205.

55 Ibíd., 283-285.

56 Ibíd., p. 195.

${ }^{57}$ Según la tradición hebrea, Moisés recibió en el Monte Sinaí tanto la doctrina escrita (Torah Shebikbtab) como oral (Torah Shebaleph). La Torá escrita está constituida por el Pentateuco ("Génesis", "Éxodo", "Levítico", "Los Números" y "Deuteronomio"), los Profetas (Neviim) y las Escrituras (Ketubim). La Torá oral comprende el Talmud (que contiene la Mishnah, que es la repetición de la enseñanza oral o precepto legal, la Gemarah, que es un comentario complementario de lo anterior, el Midrash, que son las explicaciones e interpretaciones rabínicas y el Haggadah, que consiste en relatos y explicaciones simbólicas) y la Cábala, que constituye el estudio esotérico sobre la transmisión del "secreto", al que se arriba por el método exegético Sod, que se traduce como misterio y que emplea tres procedimientos: gematría o valor numérico de las letras; la ciencia de las letras primera, media y última y la ciencia de la permutación y combinación de letras. Véase, Leo Schaya, El Significado Universal de la Cábala, traducido por Ramón del Campo Zohar, Editorial Dédalo, Buenos Aires, 1989, pp. 17-23.
} 
En el Talmud ${ }^{58}$-que constituye la primera fuente de explicación e interpretación del texto bíblico-, en Bava Kamma ${ }^{59}$ (que en adelante abrevio $B K)$ se analizó detalladamente la expresión "ojo por ojo" y se concluyó que no debe interpretarse literalmente como justicia por mano propia, sino que las personas han de buscar una autoridad judicial para que medie por su conflicto y obtener un resarcimiento económico (BK, 83b2, nota 24 y 84a2, nota 30). En síntesis, lo que el Talmud dirá según esta interpretación es lo siguiente: quien injuria a otra persona será responsable ante aquella por (todos o algunos de) los siguientes puntos: por el desprecio causado, por el dolor ocasionado, por lo que tenga que hacer la persona dañada para sanarse, por la pérdida de tiempo que le ocasionó y por haber cometido una degradación humana.

El primer criterio de evaluación se denomina nezek (BK, 83b2-84b4), que tiene que ver con la idea de menosprecio y se traduce como daño; sería necesario averiguar cuánto daño se ha causado para saber cuánto habrá que pagarse para repararlo. Otro criterio a tener en cuenta es $\operatorname{tzar}(B K, 84 \mathrm{~b} 4-85 \mathrm{a} 2)$, que se traduce como sufrimiento y responde al siguiente interrogante: ¿cuánto pagaría quien perpetró el delito para que no le saquen un ojo, o, si se lo tienen que sacar que sea sin dolor? "¿puede compensarse el dolor aún cuando no haya una herida física permanente? ( $B K, 84 \mathrm{~b} 4$, nota 34 y 85a1, nota 5). De aquí se deriva el resarcimiento que se aplica según sea el dolor causado o el padecimiento sufrido y siempre se lo evalúa desde la perspectiva de quien causó el daño. Otro parámetro es ripui (BK, 85a2-85b1), que significa cura y que responde al interrogante: ¿en qué gastos (médicos, remedios, asistencia sanitaria, otros) tendría que incurrir si me sacaran un ojo? Refiere al resarcimiento por los gastos de sanación y para su consideración hay que distinguir los casos de inadvertencia, voluntariedad y/o de compulsión en la acción. Le sigue shebet (BK, 85b1-86a2), que refiere a la idea de reparación pecuniaria por el tiempo perdido ocasionado por el daño, actualmente conocido

\footnotetext{
${ }^{58}$ Hay dos ediciones de la Gemará del Talmud, la de Jerusalem y la de Babilonia, siendo esta última la que consulté: Talmud Bavli. Tractate Bava Kamma, Vol. III (folios 83b-119b), elucidado por Rabbi Abba Zvi Naiman y Rabi Mendy Wachsman editado en Nueva York por ArtScroll Series y The Schottenstein Daf Yomi Edition y publicado por Mesorah Publications Ltd. en el año 2001.

${ }^{59}$ Bava Kamma significa en arameo "la primera puerta". Junto con Baba Metzia y Bava Batra constituyen el tratado del orden "Nezkin" del Talmud, dedicado a los daños. Contiene diez capítulos en los que se discuten tanto los daños civiles como los criminales distinguiendo, entre estos últimos, tres tipos: por hurto, por violencia y por robo. Los hechos criminales cometidos por violencia, en los que se incluye la interpretación de la venganza retributiva, se tratan en el capítulo ocho, a partir de la página 83b.
} 
como lucro cesante. Finalmente, se emplea como criterio boshed (BK, 86a2$86 a 4),{ }^{60}$ que es la vergüenza que ha padecido la víctima como consecuencia de una injuria, y para poder evaluar su resarcimiento habrá que dar respuesta a las siguientes preguntas: ¿en qué consistió el daño, ante quién fue avergonzada, quién lo escuchó u observó, qué le dijo a la víctima la persona perpetradora para avergonzarla, qué medios empleó para humillarla? ${ }^{61} \mathrm{Se}$ estableció, por otra parte, que el ítem relativo al padecimiento es independiente de los otros cuatro y que siempre se repara por separado (BK, 85a5, notas 55 y $57)^{62}$

Ahora bien, un tema de discusión frecuente en la interpretación del Talmud ha sido: ¿por qué motivo habría que interpretar como compensación pecuniaria el texto bíblico cuando explícitamente alude, en los casos de homicidio, a la pena capital?: “¿Cuál es tu razón para derivar la ley de un ser humano que injuria a otro de [la equiparación analógica con] la ley del daño a las bestias y no de la ley que gobierna el supuesto de asesinato (cuando la retaliación es la regla)?” (BK, 83b3). Una respuesta dada en este extenso y matizado debate fue que sería más apropiado derivar una ley sobre daños de los supuestos (como el caso de los ocasionados a los animales) que regulan los daños y no de los que regulan los homicidios. En contraposición, otros sostuvieron que el daño causado a las bestias no se puede equiparar con el daño ocasionado a los seres humanos, frecuentemente este último caso podría implicar alguna pérdida pecuniaria pero también, frecuentemente, en los casos de degradación humana no hay pérdida monetaria que evaluar. Quienes

\footnotetext{
$60 \mathrm{Al}$ distinguir las humillaciones intencionales de las inadvertidas, en 86a4 indica: "Porque la Torah trata la bumillación como el homicidio: ...Justo como uno no es responsable por asesinato a menos que haya tenido la intención de matar [la persona actualmente muerta]...un asesino no es responsable de ejecución a menos que haya intentado matar [esta víctima específica]" La nota 47, explica que lo que se quiere enseñar es que la pena capital sólo se impondrá a quien mate con intención...y, por medio de la nota 49 se agrega que, en consecuencia, uno puede ser responsable por injuriar aunque no haya tenido la intención de humillar, puesto que dejó a la víctima en un lugar vergonzante. Por otra parte, si la humillación fue inadvertida será responsable por una suma menor, conforme se explica esta regla en la nota 40.

${ }^{61}$ Puede observarse aquí la dimensión social que adquieren las emociones morales en la justicia, a partir del justo resarcimiento por la vergüenza causada, que se encuentra implícita en las ofensas a la dignidad humana. Aristóteles también amplió, en Retórica, su trascendencia para el entendimiento de la esfera política, sobre todo por medio de las siguientes emociones: la ira y la calma, el odio y el amor, la amistad y la enemistad, la generosidad y la falta de generosidad, la envidia, la emulación y el desprecio, el temor y el ánimo, la compasión y la indignación y la vergüenza y la des-vergüenza.

${ }^{62}$ Las notas 55 y 57 indican que aún cuando el agresor haya pagado por el daño físico deberá resarcir por el sufrimiento causado y que los otros tres rubros (sanación, lucro cesante y humillación) se derivan de este último.
} 
mantuvieron esta firme posición dijeron que entonces hay que derivar la ley de los supuestos en que los seres humanos se causan daño entre sí:

“...mejor, deberíamos decir que [el asesino] tomó el alma de [su víctima], y...en devolución deberíamos tomar el alma [del asesino]... Aquí también, refiriéndonos al daño en el ojo...-deberíamos decir que [el agresor] tomó la vista de [su víctima],... y en devolución deberíamos sacarle la vista [al agresor]..."(BK, 84a1).

Esto último me llevaría ahora a tener que considerar, en este contexto, el origen de la justificación de la aplicación de la pena de muerte asociada a una visión de justicia retributiva que claramente se contrapone con el respeto de los derechos humanos. Pues, como Carlos S. Nino dice acertadamente:

\begin{abstract}
"Muchos no vemos claro cómo la suma de un mal más otro mal puede dar como resultado, no dos males, sino un bien. Tampoco percibimos nítidamente una diferencia sustancial entre la pena retributiva y un hipotético sistema de venganza en gran escala organizado en forma monopólica por el Estado (quizás esto le sirva a alguien para sugerir que... la venganza no es tan mala cuando se lleva a cabo en forma prudente y organizada)..." ${ }^{63}$
\end{abstract}

Antes de continuar con el debate sobre el "retribucionismo vengativo" clásico, presentaré un posible significado de la venganza, tal como ha sido discutida por algunos autores contemporáneos.

\title{
3.1.2. La venganza:
}

Para algunos autores el concepto de venganza entendida como una pasión vindicativa podría llegar a ser "instrumentalmente necesario" para la justicia. Trataré de mostrar que esta hipótesis es falsa, y que la venganza es incorrecta incluso desde un punto de vista instrumental. Uno de los autores mencionados es Nico Frijda: "Lex Talionis: On Vengeance", ${ }^{64}$ y el otro, el conocido iusjurista Jeffrey Murphy: "Marxism and Retribution", 65 "Does Kant have a Theory of Punishment", 66 "Moral Epistemology, the Retributive Emotions, and the "Clumsy Moral Philosophy" of Jesus Christ"67 y Getting Even:

\footnotetext{
${ }^{63}$ Nino, Carlos Santiago, (1984), Ética y Derechos Humanos. Un ensayo de fundamentación. Buenos Aires: Astrea Alfredo y Depalma Ricardo, 2a reimpresión, 2007, pp. 448-451.

${ }^{64}$ Nico H. Frijda, (1993), "Lex Talionis: On Vengeance", S. M. Van Goozen, y otros. Emotions: Essays on Emotion Theory, Hillsdale: New Jersey, Lawrence Erlbaum, 1994, 263-290.

${ }_{55}$ Murphy, Jeffrey G., (1973), "Marxism and Retribution", Philosophy and Public Affairs, 1973, Vol. 2, p. $217-$ 243.

${ }^{66}$ Murphy, Jeffrey G., (1987), "Does Kant have a Theory of Punishment”, Columbia Law Review, 1987, Vol. 87, No. 3, 509-532.

${ }^{67}$ Murphy, Jeffrey G., (1999), "Moral Epistemology, the Retributive Emotions, and the "Clumsy Moral
} 
Forgiveness and its Limits. ${ }^{68}$

Para Nico Frijda la venganza en sí misma no es una emoción, aunque el deseo de vengar (sentirse vengativo) sí lo es, y reconoce que la cólera, el enojo y el impulso de revancha son las emociones que subyacen al potente deseo de vengar.

Según este autor, la venganza sería:

“...el acto diseñado para dañar a alguien o a algún grupo social, en respuesta al sentimiento de que uno mismo ha sido dañado por esa persona o grupo... el propósito inmediato de la revancha es, como establece la definición, hacer sufrir al [sujeto] objeto de venganza.." 69

A su vez, según Frijda, este deseo de venganza tiene tres características: 1) se trata de una pasión autodestructiva y, por lo tanto, aparentemente inútil; 2) posee tal intensidad -intensidad que se mide por la cantidad de veces que se le presenta a la víctima la profundidad de la ofensa y por el incremento de su fuerza impulsora- que es una de las emociones de mayor grado de violencia; y 3) es una emoción que persiste en el tiempo:

"...el sentimiento conectado con la revancha es el odio, definido como una disposición a valorar un objeto como un mal natural, y entonces desear que disminuya su existencia: su destrucción o pérdida es su goce vital... Asimismo, las emociones cambian a sentimientos cuando los eventos se extienden en el tiempo, o cuando el asunto no ha sido resuelto luego que el hecho terminó... ellas cambian a pasiones cuando el asunto es sentido como intolerable, y uno siente la fuerza de hacer algo al respecto..." ${ }^{70}$

Sin embargo, y a pesar de los rasgos negativos enumerados, lo cierto es que el autor sostiene que la venganza tiene un "poder social estabilizador" porque sirve para disuadir; llegando a pensar que podría haber sido "creada" como una "estrategia racional" cuyo poder estabilizador surge del temor de su ocurrencia, más que de su ejecución actual:

Philosophy" of Jesus Christ", S. Bandes (edit.), The Passions of Law, New York: New York University Press, 2001, 149-167.

${ }^{68}$ Murphy, J. G., (2003), Getting even, forgiveness and its limits, Oxford: Oxford University Press, 2003. Para una crítica a la posición de Murphy, véase: Benjamín C. Zipursky, "Coming Clean and Getting Even, Murphy on Hatred and Criminal Justice”, Criminal Justice Ethics, Summer-Fall 2008.

${ }^{69}$ Frijda, Nico H., "Lex Talionis...", obra citada, p. 265.

70 Ibíd., p. 270 
"...la venganza es un ecualizador del sufrimiento. Logra que desaparezcan partes del sufrimiento. No todo... pero una parte de él, el patetismo, la soledad, el sentirse menos que él o ella, el pensar que él o ella ha ganado... Todo esto es personal y emocional. No tiene nada que ver con el sentido de justicia. Pero la dolorosa desigualdad puede ser transformada en un plano abstracto y general y reformulada en un sentido moral que puede restaurar el balance del sufrimiento. Entonces se convierte en sentido de justicia... El sentido de justicia deriva de la reflexión sobre el sufrimiento comparativo..."

Frijda argumenta que si bien la venganza es una actividad destructiva, al mismo tiempo es instrumentalmente necesaria aunque no sea intrínsecamente valiosa. Su valor instrumental, refiere el autor, consiste en que busca reestablecer la igualdad e incluso impulsar el surgimiento de un sentido de justicia, pues permite "comparar el sufrimiento de la persona victimaria con el de la víctima". El autor agrega que el deseo de venganza surge o bien a partir del sentimiento de dolor -tanto físico como mental- ante un insulto, una lesión o una pérdida; o bien ante el desprecio, sometimiento o humillación ocasionados por otra persona o grupo social.

Frijda realiza una lista de cinco tipo de ventajas que presenta la venganza en correspondencia con cinco niveles de ofensas:

“...1) en un primer nivel establece protección contra el sentido general de amenaza que el daño inflingido por otro presenta, a través de la posible corrección del daño futuro; se corresponde con el daño como tal; 2) es un re-equilibrante de pérdidas y ganancias, un restaurador de la igualdad entre placer y dolor, que corrige el provecho y gloria del ofensor; 3) es el re-equilibrio del poder desigual que implicó no haber sido capaz de prevenir la ofensa o retornarla en su especie; 4) hace posible recapturar la autoestima... y 5) hay un alivio del dolor, a través del ejercicio de un poder elemental sobre el ofensor..."72

En síntesis, la venganza permitiría tanto corregir el daño como recobrar la igualdad de poder y recuperar la autoestima. Estas cinco supuestas ventajas de la venganza satisfacen, según el autor, el propio sentido de justicia a través de las relaciones sociales: “...la venganza no restaura la pérdida o dolor que trae aparejado el daño que he sufrido, pero le quita algo de su ventaja o gloria; oculta mi vergüenza detrás de su vergüenza y mi dolor detrás del suyo... por lo

\footnotetext{
${ }^{71}$ Ibíd., pp. 274-275.

${ }^{72}$ Ibíd., pp. 281-282.
} 
tanto la venganza es racional....”3

Este sentido instrumental y retributivo es el que convierte en racional a la venganza misma y a las pasiones relacionadas con ella. $Y$ si bien es cierto que el autor supone que es posible tener el deseo potencial de vengar a la persona agresora sin llevar a cabo una acción, sin embargo pareciera que justifica la venganza como un modo de "igualar posiciones sociales en la que el daño resulta ser la medida del desequilibrio y la retribución la recuperación de un sentido moral de justicia". Frijda pareciera entonces entender a la venganza como una pasión con sus aristas negativas, pero asimismo considera que no deberíamos desconocer su valor instrumental para recuperar la igualdad ante el daño.

Ahora bien, la objeción que formulara Nino respecto del retribucionismo en la justicia, presentada anteriormente, continúa hoy vigente ante posturas como la de Frijda: dado que el autor no alcanza a explicar en qué sentido sumar un mal a otro mal, un daño a otro daño puede convertirse en un bien, a menos que estemos pensando en el sentimiento momentáneo de una víctima ofuscada y olvidemos que la justicia es una institución social. Nino estaba en lo cierto, entonces, al sostener que el "mal" que el retribucionismo devuelve es un "mal moral" que resulta, a todas luces, "inconciliable con una concepción liberal acerca de los límites del poder punitivo estatal". ${ }^{74}$

Jeffrey Murphy también se ha ocupado en extenso de este tipo de "pasiones vindicativas" como el enojo, el resentimiento y el odio que, por lo general, nacen cuando alguien ha sufrido un daño profundo infligido por otra persona. Si bien Murphy considera que las pasiones vindicativas son siempre actitudes reactivas, también afirma que es posible tenerlas sin llegar a actuar a partir de ellas con venganza o revancha. En este punto coincide con Frijda. Murphy define a la venganza como el acto de "...inflingir sufrimiento a una persona a fin de satisfacer pasiones o emociones vindicativas..."75 En tal sentido, explica que: “...el propósito de la venganza es simplemente proveer satisfacción vindicativa a las víctimas, y las víctimas pueden requerir algo,

\footnotetext{
${ }^{73}$ Ibíd., p. 282

${ }^{74}$ Nino, C. S., Ética y Derechos Humanos..., obra citada, p. 450.

75 Murphy, J., Getting Even..., obra citada, p. 17.
} 
entonces, que es necesario para controlar el crimen o para darle a los malhechores su merecido..."76

De este modo, el autor encuentra que la venganza "legitima un sistema de punición criminal que es funcional a cierto modelo de justicia penal" y, sobre la base de ello, propone -adaptando el sermón "Sobre el perdón de las injurias" del Obispo anglicano Joseph Butler- transmutar la venganza en perdón.

Murphy define al perdón como: “...una virtud moral (una virtud del carácter) que es materia esencial del corazón, del yo interior, y que envuelve un sentimiento íntimo más que un cambio de acción externa..." 77 No es lo mismo el perdón que otras respuestas análogas que pueden confundirse con el perdón, como por ejemplo la justificación. Justificar significa que una conducta típicamente incorrecta está amparada bajo ciertas circunstancias, como sucede con los casos de legítima defensa. Tampoco el perdón es equivalente a la excusación. Excusar significa considerar que la persona que comete un delito no tenía, al momento de los hechos, suficiente capacidad para asumir responsabilidad por su acto. Tampoco es equivalente a la misericordia, en la que bajo ciertas reglas institucionales se inflige un daño menos duro a quien perpetró un hecho delictivo; o que la reconciliación, que implica un proceso de partes en el que se permuta la pena por la verdad sobre los hechos investigados, sin perjuicio de reparaciones materiales ulteriores, como el caso de la Comisión por la Verdad y la Reconciliación de África. Sobre esto último Murphy aclara con razón, que puede haber reconciliación de partes sin que haya perdón de las víctimas.

En consecuencia, si bien Murphy sostiene que las pasiones vindicativas constituyen una barrera para una sincera reconciliación, también afirma que, y a pesar de la visión negativa que tienen porque provocan conductas destructivas, cumplen un rol importante en la psicología y en la moral humana puesto que están vinculadas con los valores relativos al auto-respeto y la autodefensa. En realidad para Murphy incluso el odio y el resentimiento son formas de afirmación del auto-respeto aunque no queda claro, como lo han 
dicho bien sus críticos, si eso implica que quien no odia o no está resentido es moralmente malo o vicioso, y si es obligatorio sentir odio ante un daño injustamente infligido, so pena de caer en una conducta moralmente disvaliosa.

Lo cierto es que Murphy siempre ha creído que tales pasiones cumplen una función social y un rol importante en el ámbito de la justicia criminal, especialmente a través de las declaraciones testimoniales de las víctimas, que en su criterio se encuentran plagadas de expresiones de odio, resentimiento y enojo. Según Murphy, “...a pesar de que esas declaraciones están a veces fundadas en súplicas de perdón o misericordia de carácter religioso, la mayoría de las veces son formas de expresar enojo (y presumiblemente vindicativas) a la autoridad que sentencia, para que imponga la mayor dureza posible en el fallo...,"78

Hasta aquí he mostrado dos teorías que directa o indirectamente le reconocen valor instrumental a las pasiones vindicativas y comparten una concepción retributiva de la pena, buscando satisfacer el deseo de vengar mediante una "transferencia" del sufrimiento desde la persona que lo ha padecido hacia la persona condenada. Pero, si la aplicación de la pena busca hacer "escarmentar", "sufrir" y "ocultar" entonces, y sin perjuicio del alcance de la pena, el deseo de la víctima se encuentra satisfecho y legitimado en un sistema de retribución punitiva: que sufra, se retuerza y quede bien oculto de la sociedad.

Pero, ¿es esto justicia?, ¿qué buscamos, cuando buscamos justicia?

En su obra "Sympathy and Vengeance: The Role of the Emotions in Justice", Robert Solomon se ha ocupado del tema sin defender una teoría retribucionista de la pena. Según Solomon, no puede haber un entendimiento adecuado de nuestro sentido de justicia sin una apreciación y comprensión de nuestras emociones. Además, a su entender, las emociones negativas como la indignación y la venganza:

"...son una parte de nuestra naturaleza humana e igualmente esenciales para la justicia, no son solamente fisuras del carácter o

\footnotetext{
${ }^{78}$ Ibíd., p. 27.
} 
[muestras] de debilidad humana... las emociones no juegan un rol inferior en las deliberaciones sobre justicia, y es falso que las emociones sean más primitivas, menos inteligentes, más bestiales, menos dependientes y más peligrosas que la razón. La Justicia [además] implica una emoción racional, que no es ni meramente desapasionada ni meramente emocional... El sentido de justicia (y de injusticia) no es un episodio... es siempre un modo de vida... las emociones constituyen un marco de racionalidad en si mismas... "

Para Solomon tanto las emociones "simpáticas", entre las que podríamos mencionar la piedad o la compasión, como las "antipáticas", como el rencor, la envidia, los celos y la venganza; todas ellas, y en virtud de su contenido cognitivo, forman parte de nuestro sentido moral de justicia. Según el autor, el problema evidente del debate entre retribucionistas y prevencionistas en torno a la función de la pena en la justicia es que en el mismo se omite mencionar que "las emociones son el combustible de una noción de pena basada en la venganza"; y Solomon se encarga de recordar que su perspectiva sobre la racionalidad de las emociones no implica en modo alguno una justificación de la venganza como modo de hacer justicia, tesis que comparto con el autor.

En un trabajo distinto: "Justice v. Vengeance. On Law and the Satisfaction of Emotion", ${ }^{80}$ Solomon profundizó su crítica al retribucionismo, acusándolo de amparar tres patrones sociales que satisfacen legalmente la venganza: primero el que contiene la idea de deuda relacionada con la persona ofensora: expresada en la famosa frase "el que las hace las paga", persona a la que se alude con el mote de "culpable", en lugar de apropiadamente responsable. Detrás de esta idea de deuda hay una medida y una conmensurabilidad retributiva. El segundo patrón social que menciona el autor contiene una idea de armonía social, vinculada analógicamente con la importancia del equilibrio homeostático en el ser humano. Es así, entonces, que la satisfacción vengativa opera como un ecualizador del equilibrio social porque reduce o elimina la desarmonía. Finalmente, el tercer patrón social del retribucionismo, según Solomon, es el que se relaciona con la idea de polución, en el sentido de que quien comete un crimen tiene que ser "limpiado". Frases

\footnotetext{
79 Robert Solomon, "Sympathy and Vengeance: The Role of the Emotions in Justice", en Emotions: Essays on Emotion Theory, de S. M. Van Goozen y otros, Hillsdale, New Jersey: Lawrence Erlbaum, 1994, pp. 291-312.

${ }^{80}$ Solomon, Robert C., (1999), "Justice v. Vengeance: On the Law and the Satisfaction of Emotions", S. Bandes (edit.), The Passions of Law, New York: N ew York University Press, 2001, pp. 123-148
} 
como "limpiar las calles" (en alusión principalmente a personas pobres), "pagar sangre con sangre" o "sacarlos de la vista" forman parte, según Solomon, de esta idea retributiva del castigo, que refiere al crimen como un factor de desequilibrio social. De este modo "limpiar" a la sociedad de criminales implica una forma de satisfacer un deseo de venganza respecto de quienes resultan objeto de repulsión, así lo explica lúcidamente Solomon. Volveré sobre este punto al analizar la sentencia condenatoria elegida.

Aunque hay abundante literatura sobre la relación entre emociones y justicia -sobre todo en el ámbito de la criminología y de la filosofía contemporánea-, hasta el momento hay pocos trabajos científicos publicados en Argentina que den respuesta al interrogante planteado al inicio de esta investigación, es decir, que presenten un marco teórico bajo un ideal de justicia que, al mismo tiempo que considere y refleje en los actos de justicia decisorios las emociones morales expresadas por las partes y testigos en los procesos judiciales, sea respetuoso de los derechos humanos de personas víctimas y victimarias, sin estar vinculado directa o indirectamente con emociones vindicativas o con algún modelo de punición retributiva.

Quien en nuestro ámbito académico más se ha aproximado a la cuestión ha sido Jaime Malamud Goti, en su artículo "Dignidad, venganza y democracia", ${ }^{81}$ en el que planteó una respuesta a lo que él denomina "retribucionismo tradicional", basado en emociones vindicativas, analizando específicamente los conflictos posteriores a la dictadura, generados en la Argentina como consecuencia de los juicios seguidos a personas violadoras de los derechos humanos en la década del setenta.

Según el autor, tanto la posición retribucionista deontológica que mira lo pasado sin importar las consecuencias de los hechos (menciona aquí las posiciones de H. L. A. Hart, J. Rawls, R. Nozick e incluso la postura de "Madres de Plaza de Mayo" y organizaciones internacionales como "Amnesty") como las posiciones disuasivas utilitaristas (cuyos máximos exponentes son Bentham y Mill), se centran en el "autor" del crimen. En contraposición, Malamud Goti,

\footnotetext{
${ }^{81}$ Jaime Malamud Goti, "Dignidad, venganza y democracia" en Revista Jurídica de la Universidad de Palermo, Año
} 5, No. 1, 2000, pp. 135-160. 
propuso un modelo de "retribucionismo de fines", centrado en el sufrimiento de las víctimas: Dice el autor:

"Propongo, entonces, una justificación de juicios y castigos criminales "fundada en la víctima», en las emociones moralmente relevantes del que sufre, como una razón independiente para justificar la condena de violadores de derechos humanos... el castigo debe dirigirse a reparar el daño emocional que la violación ha causado. No me refiero a emociones vindicativas, sino a otros sentimientos vinculados con la dignidad de las víctimas, como la pérdida de autoestima y de propósitos. ${ }^{, 82}$

El "retribucionismo de fines" planteado por Malamud Goti -aunque intente desprenderse de la idea de pasiones vindicativas asociadas al mismocontiene la noción de devolución punitiva. Cuando el autor habla de reparar la pérdida de autoestima y de propósitos de las víctimas como función central de la reparación del daño, esta indicando que lo que se intenta es restaurar la dignidad humana perdida. Su hipótesis parte de la premisa de que la "vergüenza", como sentimiento moral que un hecho particular ocasionó a la víctima, justifica el castigo a quienes hayan causado humillación. Malamud Goti insiste en que dividir el proceso penal entre culpables e inocentes fracciona a la sociedad y supone un esquema bipolar que es incompatible con una república democrática:

“...establecer quiénes son moralmente responsables de la infracción de derechos humanos en una sociedad aterrorizada genera un inevitable ingrediente de artificialidad. Al centrar la culpa en un limitado sector de la población, los juicios de derechos humanos reinventan la historia. De esta manera, el significado de la "verdad» resultante, frecuentemente percibida como facciosa, es objeto de disputas inzanjables. ${ }^{, 83}$

Si bien Malamud Goti ha efectuado un avance importante al señalar que la vergüenza y la humillación son aspectos emocionales humanos centrales en los asuntos llevados a los estrados judiciales, especialmente en aquellos que tienen que ver con violaciones masivas a los derechos humanos por estados dictatoriales; su teoría no explica cómo funciona dicho retribucionismo de fines en relación con la apreciación del hecho delictual por parte de quien lo ha perpetrado, porque no busca una restauración de la dignidad humana en la persona victimaria, ni tampoco hace un balance en torno a la mirada de quien

\footnotetext{
${ }^{82}$ Malamud Goti, J., obra citada, p. 142.

83 Ibíd., p. 144.
} 
juzga los hechos; alegando Malamud Goti solamente que en los juicios postdictatoriales se produjo una "falta de autoridad política" que, según él, se traduce como una suerte de falencia por parte de la autoridad judicial por haberse ocupado de juzgar a los militares y no a todas las personas que estuvieron implicadas en distintos niveles en el conflicto.

Considero que la concepción del retribucionismo punitivo -ya sea que se centre en las víctimas o en los victimarios- continúa manteniendo implícita la idea de que la forma de "castigar" a los criminales por el mal causado es la devolución. En un caso, mira a quien cometió un crimen, sin considerar las emociones relevantes de las víctimas, y en el otro, mira a las víctimas sin atender las emociones morales preponderantes que llevaron la persona victimaria a cometer el delito.

El retribucionismo -en todas sus facetas- es una forma de punición que resulta incompatible con el respeto igualitario de los derechos humanos de todas las partes comprometidas en un proceso judicial.

Una visión sesgada sobe el alcance de los derechos humanos en el ámbito de la justicia penal podría intentar demostrar que los derechos humanos sólo deberían proteger los derechos de quienes delinquen, mucho más aún cuando se ha evolucionado en los últimos años significativamente sobre la mayor protección de los derechos de las personas privadas de su libertad. Otra visión también sesgada podría defender la aplicación de penas que respondan a pasiones retributivas de las víctimas, como una forma de legitimar un deseo colectivo de punición respecto de perpetradores de delitos ultrajantes, sobre todo en hechos de significativa trascendencia social. Por otra parte, los estados podrían adoptar políticas criminales tendientes a demostrar el descenso de la tasa de criminalidad en distintas secciones delictuales (crimen organizado, secuestros extorsivos, narco-criminalidad, violaciones seguidas de muerte, como algunos ejemplos más populares que podrían ser tomados para medir crimen en las sociedades) y podrían inducir temor a delinquir, mediante la elevación de los años en las condenas o el endurecimiento de las penas, satisfaciendo, de tal modo, el clamor de cierta parte de la sociedad de establecer mayor seguridad ciudadana. 
Pensar en términos de respeto por los derechos humanos implica pensar en todos los seres humanos: en las personas víctimas y victimarias. $Y$ también es preciso pensar en la sociedad como víctima indirecta de las lesiones producidas a individuos en particular, puesto que el daño que se ocasiona a una persona lo es a todos, en tanto que somos parte de la misma especie y compartimos valores universales como la vida, la libertad y la integridad física, sexual, psíquica, emocional y espiritual.

En síntesis, todas las emociones morales tienen un elemento cognitivoevaluativo que está presente en los procesos judiciales, nos gusten o nos disgusten. Pero también es posible aseverar que ciertas pasiones vindicativas entran en una grosera colisión con una idea de justicia respetuosa de los derechos humanos, y más aún cuando son funcionales al poder coercitivo de los estados. En lo que sigue examinaré en qué consiste el contenido emocional de la ira porque junto con la repugnancia son las dos emociones de mayor presencia en la sentencia elegida para aplicar el marco teórico y porque por lo general también juegan un papel importante en los esquemas de justicia retributiva que he analizado antes.

\subsubsection{La ira. Relevancia de la discusión de Séneca con Aristóteles}

Es común afirmar que el deseo de venganza va acompañado por un estado colérico, una furia emocional, un gran enojo e indignación por el avasallamiento a la dignidad humana. Esta afirmación es parcialmente verdadera, pues hay casos de venganza que no están acompañados por estados coléricos, y porque la ira no siempre conduce a un sentimiento irracional y retributivo de venganza.

Los pensadores griegos que se interesaron por el tema de las emociones en relación con la justicia y la imputación jurídica de acciones y personas no ignoraron la posible relación entre la ira y la venganza, pero insistieron en que la ira no es ajena a la razón y que, como sostuvo Aristóteles, puede tener una función importante en la evaluación de acciones y personas.

Me extenderé sobre las posiciones de Aristóteles y Séneca en este punto porque, si bien tienen raíces comunes, su valoración sobre la importancia 
social y política de la ira es muy diferente y, además, porque ambos autores son la fuente de la que se nutre la teoría de las emociones de Martha Nussbaum.

Séneca escribió un breve tratado Sobre la Ira -cuya datación es inexacta, posterior al 41 y anterior al 52- al cual le dedicaré una parte de la exposición. Se trata de uno de los diálogos de Séneca más estudiados, el más largo y que consta de tres libros y que, como suponen los comentaristas, es muy posible que recibiera distintas influencias: de Aristóteles, en primer lugar, pero también de Crisipo, de epicúreos como Filodemo, y del Libro IV de Tusculanas de Cicerón. El texto tiene como destinatario a su hermano Novato, y esto es importante porque Novato le dedicó su vida a la política.

En varios pasajes de su escrito, Séneca discute abiertamente la teoría aristotélica acerca de la supuesta necesidad de la ira -que pone en boca de Novato- como forma de poner en movimiento el alma y como una reacción lógica ante conductas que califica como malas o reprensibles.

Un tema recurrente en el texto de Séneca es rebatir la pretendida utilidad de la ira, alegada por Aristóteles; así dice al respecto: “...Aristóteles se manifiesta defensor de la ira, y no prohíbe extirparla. Dice que ella es el aguijón de la virtud...". ${ }^{84} \mathrm{Y}$, continúa: “...existe alguien, y por cierto de los más ilustres filósofos, que le atribuye una tarea y, como si fuera útil y ofreciera ánimos para el combate, para la acción, la invoca para cualquier cosa que se haya de llevar a cabo con cierto ardor. ${ }^{85}$ Uno de los argumentos recurrentes de Séneca es que nunca un "vicio" puede ser el compañero de la virtud, entendiendo por virtud un estado de control de las pasiones y especialmente de la ira, que para él siempre es un exceso, intrínsecamente mala, que no admite términos medios y debe ser erradicada.

Aristóteles, por el contrario, definió a la ira (orgē) como “...un apetito penoso de venganza manifiesta a causa de una ofensa ostensible hacia uno o

\footnotetext{
${ }^{84}$ Séneca, L. A., De la ira, traducción directa del latín por Francisco Navarro y Calvo, Alicante: biblioteca virtual Miguel de Cervantes, 1999, III, 3, p. 30.

85 Séneca, De la Ira,...obra citada, III, 3, p. 30.
} 
hacia alguno de los nuestros, no estando la ofensa justificada..." ${ }^{86} \mathrm{Y}$, estableció una diferencia entre tres tipos de ofensas que originan la ira: el desprecio, la humillación y el ultraje. En Ética Nicomaquea, sostuvo que es elogiable aquel que se aíra, “...por las cosas que se debe y contra los que se debe, y como se debe, cuando y durante el tiempo que se debe... Ese sería pues apacible... pues quiere estar libre de inquietud y no quiere dejarse llevar por el afecto, sino irritarse del modo... que la razón mande..." 87 Para Aristóteles entonces, y a diferencia de Séneca, hay un modo virtuoso de comportarse en relación con la cólera, que consiste en encolerizarse como la razón lo ordena, por el motivo correcto, el tiempo correcto, etc.

A diferencia de Aristóteles, en De la Ira, Séneca caracterizó a la misma como: “...toda agitación, desenfreno en el resentimiento, sed de guerra, de sangre, de suplicios, arrebato de furores sobrehumanos, olvidándose de si misma con tal de dañar a los demás, lanzándose en medio de las espadas, y ávida de venganzas que a su vez traen un vengador. ${ }^{888}$ Para el estoico romano, la ira es una "breve locura" que resulta repugnante a la naturaleza humana puesto que está ávida de venganza, no sólo contra quien ofende sino que también contra quien resulta una amenaza ofensiva y, por lo tanto, consiste en el deseo y no en la facultad de castigar; añadiendo que se revela con manifestaciones corporales de inflamación en los ojos, cabellos erizados, enrojecimiento del rostro, respiración entrecortada, dientes apretados, miembros temblorosos y agitación general del cuerpo.

Son múltiples las razones que aduce Séneca para proponer la erradicación total de la ira. Entre otras: "que no hay pasión más ansiosa de venganza que la ira" porque, según él:

"Irritarse por los propios no es de ánimo piadoso, sino enfermo. Lo bello y lo digno es mostrarse defensor de los padres, de los hijos, de los amigos, de los conciudadanos, ante la voz del deber; defensor voluntario, reflexivo, previsor, y no ciego y furioso. No hay pasión tan ávida de venganza como la ira...,

\footnotetext{
86 Aristóteles, RET, II, 2, 1378a.

87 Aristóteles, EN, IV, 5, 1126a.

${ }^{88}$ Séneca, De la ira, obra citada, I, 1, p. 1.

89 Obra citada, I, XII, p. 7.
} 
Séneca sostuvo esta posición en su discusión con Teofrastro, quien creía en la imposibilidad de que un hombre bueno no se encolerizara frente al mal. El argumento de Séneca en este punto era que nada es menos adecuado que el que castiga se encolerice puesto que, para él, el castigo es más útil para corregir si se impone después de reflexionar: "Por ésta razón dice Sócrates a su esclavo: 'te azotaría si no estuviera encolerizado'. Dejaba para un momento más tranquilo la corrección del esclavo y al mismo tiempo se corregía a si mismo" ${ }^{90}$ Se trata, en este caso, de argumentos de todo punto vista consecuencialistas, como también lo es el argumento -político de cabo a rabosobre la conveniencia de abstener la ira ante las distintas "clases" de hombres:

\begin{abstract}
"Necesario es abstenerse de la ira, sea contra un igual, sea contra el superior, sea contra el inferior. El resultado de la lucha con el igual es problemático; luchar con el superior es insensato, y vil con el inferior... La lucha cesa en cuanto uno de los dos abandona el puesto: para combatir se necesitan dos... Te ha golpeado, retírate.". ${ }^{91}$
\end{abstract}

Ambos filósofos, Aristóteles y Séneca, afirmaron que la ira interactúa con la razón e incluso llegaron a sugerir que la ira se manifiesta como una agitación del pensamiento. Uno y otro coincidieron, además, en sostener que el deseo de vengar yace en la ira, y que lo que se busca en el fondo es devolver el daño. Sin embargo, Séneca calificó a la ira como un vicio detestable y deforme, una suerte de tirano interior que lo único que ocasiona es una violencia indomable, que por lo tanto carece de valor instrumental y que hay que arrancar, refrenar o moderar:

"En todo es desigual la ira... Porque se complace en sí misma, no quiere escuchar nada, no deja tiempo a la defensa, se adhiere a la idea de que se ha apoderado, y no sufre que se altere su juicio, por malo que sea... y comprometida en el mal camino, la obstinación le parece más honrosa que el arrepentimiento... cuánta es la violencia de esta ira, que no pudiendo desfogar sobre otro tan pronto como quisiera, se revuelve contra si misma....".

Por ello, Seneca aconseja tolerar con paciencia y resignación algunas ofensas, sugiriendo que la ofensa no es más gravosa que la ira y que si alguien es capaz de soportar su propia ira, podrá también tolerar la ofensa ajena:

\footnotetext{
${ }^{90}$ Ibíd., I, XV, p. 8.

${ }^{91}$ Ibíd., II, XXXIV, p. 27.

92 Ibíd., 1, XVI, p. 10.
} 
“...Seamos, pues, más tolerantes recíprocamente: malos, vivimos entre malos. Una sola cosa puede devolvernos la tranquilidad: ...nuestra tolerancia. Aquel me ha ofendido; no le he devuelto la ofensa; pero tal vez habrás ofendido ya a otro o le ofenderás... ${ }^{, 93}$

La posición de Séneca en este punto es lo opuesto a una teoría retributiva del castigo, por razones muy propias, pues propone llevar una vida de tranquilidad en el alma, suavidad en los actos y bondad en el corazón, extirpando las emociones que perturban el ánimo; aunque también sugiere (¿acaso con ironía?): ¿¿Puede tu ira desear al enemigo algo más grande que la muerte? Permanece tranquilo, que morirá: pierdes el trabajo al querer hacer lo que ha de suceder.,94

Pero para Aristóteles, la ira no es un vicio sin más, incluso en su justa medida puede llegar a ser virtud, y el problema no es la ira sino la incontinencia que recae tanto en el exceso como en el defecto de ira: el iracundo y el pusilánime. Este último, el pusilánime, que no se indigna ante la injusticia es vicioso porque no desarrolla la capacidad de encolerizarse por las cosas que se debe (airar), con quien es debido y en el momento debido, "...dando la impresión de que no sienten ni se duelen, y de que, como no se ofenden, son incapaces de defenderse; y soportar que a uno se lo insulte y contemplar con indiferencia que [se] insulte a los suyos es, en la opinión de todos, servil...,05 Es claro, entonces, que Aristóteles no aceptaba la indiferencia estoica como virtud, al menos en el ámbito de la política.

En relación con la incontinencia por exceso de la ira, Aristóteles señala los siguientes estados emocionales: la irascibilidad, que se presenta en quien se enfurece pronto contra quien no debe, por lo que no debe y más de lo que debe y luego se calma rápidamente; la cólera, que se presenta en quienes son vehementes e irascibles contra todo y por todo; la amargura, que presentan quienes permanecen airados por más tiempo que el debido y solo calman su furia con "la venganza" o "el castigo", mientras tanto se mantienen apesadumbrados. Incluso luego, al referirse a la incontinencia como forma del carácter que se debe evitar, Aristóteles dice que la incontinencia de la ira es

\footnotetext{
93 Ibíd., 3, XXVI, p. 42.

${ }^{94}$ Ibíd., 3, XLIII

95 Aristóteles, EN, IV, 5, 1126 a.
} 
menos vergonzosa que la de los apetitos sin más, porque la ira, en ese caso escucha a la razón aunque la escucha mal, oye a la razón pero no se entera de lo que ésta le ordena, y se lanza "hacia al goce", a la venganza... Y, añade que son más injustos los más solapados que urden con engaños, ya que ni el colérico ni el irascible son solapados sino que obran abiertamente. En cambio, el que envuelve con palabras seductoras hace perder el juicio hasta al más prudente. Finalmente, agrega Aristóteles que nadie ultraja a otro con dolor o disgusto, pero que quien obra con ira sí lo hace, mientras que quien ofende a otro lo hace con placer: “...así pues en el impulso [agresivo] no hay ultraje...". 96

En consecuencia según la teoría aristotélica la ira tiene un componente cognitivo-evaluativo que constituye el marco de referencia moral de la persona que experimenta dicha emoción en los siguientes sentidos: primero, el objeto emocional de la ira es la ofensa causada a la persona ofendida o a sus seres queridos; segundo, la intencionalidad de tal objeto emocional: "el sentirse ofendido", es definido por la percepción que esa persona tiene sobre si misma y sobre su propia vida, o sea, lo que es digno de valor para ella; y finalmente, tercero, la ira contiene una o varias creencias (valorativas) sobre la ofensa cometida, que consisten en la identificación con cierta estructura mental respecto de un objeto, sujeto o idea.

Es preciso recordar -siguiendo a Aristóteles- que las emociones no son simples formas de desencadenar acciones futuras, sino que también dan cuenta de los hechos que se sucedieron, de la importancia intrínseca que los eventos han tenido lugar en la vida de cada ser humano, y de cómo ese hecho afectó su dignidad, autoestima, autorrespeto y confianza, en relación con su prójimo.

Al estudiar el rol que la pasión desempeñaba en la esfera pública bajo la perspectiva estoica, Martha Nussbaum en La Terapia del Deseo (1994) analizó la discusión precedente y afirmó que Séneca, básicamente, propiciaba la eliminación de la cólera para contribuir al cultivo de la propia humanidad sosteniendo para ello tres argumentos centrales:

${ }^{96}$ Aristóteles, EN, VII, 6, 1149b 
- La ira es una construcción social artificial, producto del juicio, ya que se basa en la creencia transmitida, valorada y justificada del empleo de la fuerza corporal.

- La ira es innecesaria e inútil para motivar el comportamiento adecuado, puesto que la razón es suficiente para guiar la acción virtuosa y el deber.

- La ira es un exceso que nos deja fuera de control y nos conduce a la violencia y la crueldad.

El análisis de Nussbaum gira en torno al argumento motivacional, o sea, a los distintos motivos que mueven a actuar una persona irascible y a otra que no lo es -a la que Séneca denomina "persona de bien"-, ante un hecho aberrante.

Nussbaum reconstruye el primer caso de la siguiente manera: el juicio de la persona irascible estaría conformado del siguiente modo: “...la creencia de que se ha cometido una ofensa deliberada, que ésta es en cierto modo importante y que sería bueno que la venganza cayera sobre el que la ha cometido...". 97 Empero, la persona no airada haría la siguiente evaluación: se trata de "...una injuria deliberada y culpable, hecha a alguien que es importante para mí, alguien a quien yo estoy obligado a proteger. El autor de la ofensa ha de sufrir por lo que ha hecho...". 98

Nussbaum acierta al decir que la diferencia recae solamente en el estado emocional subjetivo de cada uno de las personas, pues ambas reconocen un daño infligido a otro ser humano que es importante para sí, y ambos claman un castigo para el agresor, el primero apasionadamente y el segundo deliberadamente (el estoico, "casi como un actor en escena", refiere la autora). En consecuencia, el estoico se encontrará libre de sufrimiento ante el daño causado por la persona agresora y buscará, dentro de los parámetros que la sociedad establece (normas sociales), que aquella repare públicamente el daño ocasionado justificando, incluso al extremo, la aplicación de la pena de muerte, por estimarla buena para ella. La autora advierte aquí un primer inconveniente en la teoría estoica del castigo proporcional, que tendría que ver con una falta de compasión ante el sufrimiento ajeno, tanto respecto de la

\footnotetext{
${ }^{97}$ Nussbaum, M., La Terapia del Deseo..., obra citada, p. 512.

98 Obra citada, p. 511.
} 
persona víctima como de la victimaria. $Y$ bien afirma ello la autora, puesto que llega a decir Séneca sobre el castigo:

\begin{abstract}
"Si tengo que vestir la siniestra toga del juez, si la fúnebre trompeta ha de convocar a la multitud, subiré al tribunal, no como iracundo o enemigo, sino con la serena frente de la ley; pronunciaré la solemne sentencia con voz antes grave y tranquila que arrebatada, y ordenaré la ejecución con severidad, pero sin ira. Y cuando mande cortar la cabeza al culpable, y cuando haga coser el saco del parricida, y cuando remita al suplicio militar, y cuando coloque sobre la roca Tarpeya al traidor $y$ al enemigo público, no experimentaré ira, tendré tanta tranquilidad en el rostro y en el ánimo como cuando aplasto un reptil o animal venenoso... el buen juez condena lo que la ley reprueba; no odia... La pasión cae pronto; la razón permanece siempre igual. En este último caso, aunque la ira tenga cierta duración, si encuentra muchos culpables que hayan merecido la muerte, después del suplicio de dos o tres cesa de matar". 99
\end{abstract}

Este pasaje es muy importante para esta investigación, porque Séneca argumenta sobre la inconveniencia de la ira para tomar las decisiones correctas, pero al mismo tiempo describe una actitud de una autoridad judicial no iracunda pero que sin duda le quita humanidad a la persona condenada por considerarla equivalente a una "serpiente venenosa"; aunque el pasaje citado estaría en abierta contradicción con otro argumento de Séneca que se refiere al castigo racional, libre de ira:

"...El hombre ha nacido para ayudar al hombre; la ira para la destrucción común... La vida humana descansa en los beneficios y la concordia; y no en el terror, sino el amor mutuo... -iCómo! ¿El castigo no es a veces una necesidad? -Ciertamente, pero debe ser justo $y$ razonado; porque no daña, sino que cura aparentando dañar.".100

Pero, ¿cómo es posible curar a quien se considera una serpiente venenosa?, ¿cómo ayudar a quién no se considera ser humano?

Para Séneca el origen de la agresividad y de los vicios que la misma conlleva son circunstanciales, producto de la interacción humana, es la condición humana que surge como consecuencia del apego y de la lucha por los bienes mundanos, puesto que, para él, nada propicia más la cólera que el lujo desmesurado y desordenado. Es así como proclama que: “...debemos tratar nuestra alma con dureza, para que no sienta los golpes..."101; pero esta

\footnotetext{
${ }^{99}$ Séneca, L. A., obra citada, I, XVI, p. 9.

100 Obra citada, I, V, p. 3.

101 Ibíd., II, XXVI, p. 22.
} 
actitud que propone resulta contraria a la naturaleza humana puesto que, como hemos visto, también afirma que ser humano es aprender a vivir en amor y concordia.

Entonces, el argumento central de Séneca consiste en demostrar que la persona airada, que vive indignándose por las injusticias del mundo, aumenta y refleja la cólera potenciando dentro suyo la agresividad a la que le otorga mayor importancia con dicho comportamiento,

“...una persona que acusa cada injusticia y reacciona contra ella ha de acabar, al reaccionar con ira, volviéndose semejante a las personas coléricas y furiosas contra las que reacciona. La cólera endurece el espíritu y lo vuelve contra la humanidad que tiene ante si. $Y$ al volverse contra la humanidad se vuelve uno peligrosamente próximo a los tipos crueles y agresivos que provocaron el descontento...". ${ }^{102}$

Séneca deshecha una a una las posibles causas de la ira: no nos podemos encolerizar por aquellos que "no son capaces de dañarnos", como los dioses (que ni quieren ni pueden perjudicar) porque su naturaleza es suave y plácida; ante los fenómenos naturales que poseen leyes propias que rigen lo divino como las tempestades y los inviernos (nos sobreestimaríamos si creyéramos que somos dignos de que por nosotros se pusieran en movimiento cosas tan importantes); tampoco por los que "no quieren dañarnos", como los buenos "magistrados, padres, preceptores y jueces", cuyas reprimendas hay que considerar como un bisturí que tortura para beneficiar; tampoco con quienes nos injurian (si alguien ha hablado mal de ti, piensa cuántas veces has hablado mal de otros), etc. En síntesis, según Séneca no debemos encolerizarnos en los siguientes casos:

“¿Es un niño? se le perdona la edad; ignora, si hace daño. ¿Es un padre? o nos ha hecho bastante bien para adquirir derecho a una ofensa, o tal vez es un favor más el que tomamos por injuria. ¿Es una mujer? se engaña. ¿Es por mandato? ¿Quién podría, sin injusticia irritarse contra la necesidad? ¿Es por represalia? No se te injuria si sufres lo que tú has hecho sufrir antes. ¿Es un juez? respeta más su sentencia que la tuya. ¿Es un rey? si te castiga culpable, cede a la justicia; si inocente, cede a la fortuna. ¿Es un animal irracional u otro ser parecido? te haces semejante a él irritándote. ¿Es una enfermedad, una calamidad? más pronto pasará si la soportas. ¿Es un dios? Pierdes el trabajo irritándote contra él, lo mismo que al invocar su cólera contra otro. ¿Es un varón justo el que le ha injuriado? no lo creas. ¿Es un

102 Nussbaum, La Terapia del Deseo..., obra citada., p. 520. 
malvado? no te asombres; otro le castigará por lo que te ha hecho; y ya lo está por la falta misma que ha cometido... Dos circunstancias... excitan la ira: primera, si creemos que se nos ha injuriado... segunda, cuando nos parece que ha sido injustamente...". ${ }^{103}$

Hay varios tópicos en este pasaje que conviene comentar. En primer lugar, Séneca coloca a todas las causas de una posible reacción airada en un mismo plano: a los fenómenos naturales, como las enfermedades y las calamidades; a quienes no realizan acciones claramente voluntarias porque "no saben lo que hacen", como los niños, o porque siempre se equivocan, como las mujeres; a quienes detentan relaciones de autoridad y poder real y judicial; a seres humanos buenos y malos en general. En todos los casos, el argumento parece ser el mismo: la ira endurece el espíritu y se vuelve en contra de la propia humanidad.

Pero, utilizando la útil distinción aristotélica de acciones voluntarias, involuntarias y mixtas es fácil ver que en las acciones de la realeza y de quien ha recibido la orden se introduce un matiz interesante. Para Aristóteles, son voluntarias las acciones "cuyo principio está en el agente en el momento de actuar" e involuntarias aquellas en las que no tiene parte alguna el agente o el paciente. ${ }^{104}$ Aristóteles dice también con claridad que aquellas acciones que se hacen por temor a mayores males o por una causa noble -por ejemplo, si una persona tirana mandara a alguien a cometer una acción denigrante, teniendo en su poder a sus padres o sus hijos y éstos se salvaran si lo hiciera y parecieran si no lo hiciera- son acciones mixtas, que se parecen a las involuntarias pero más a las voluntarias, porque son preferibles en el momento en que se ejecutan y estuvo en manos del agente el hacerlas o no hacerlas.

Lo cierto es, como bien señala Nussbaum, que la diferencia central entre Aristóteles y Séneca parece ser la siguiente: en el caso de Aristóteles la ausencia de ira es incompatible con el respeto por la humanidad, mientras que en Séneca es justamente lo contrario. Nussbaum considera que a diferencia de los escépticos, lo que Séneca nos propone ante la ira no es un distanciamiento o enfriamiento en la interacción humana sino una justa valoración del objeto de enojo y un acercamiento amable hacia el prójimo acorde con nuestra

\footnotetext{
103 Séneca, L. A., obra citada, II, XXX, pp. 24-25.

104 Aristóteles, EN, obra citada, Libro III, I, 110a.
} 
naturaleza amorosa. Puesto que al encolerizarse la persona se pone por encima de otro ser humano, provocando una jerarquización en los vínculos.

En este punto Nussbaum sostiene que a diferencia de la mayoría de los estoicos que mantenían un estricto apego a los principios de verdad y deber legal, Séneca logró aproximarse a la tradición aristotélica de epieíkeia: esto significa que el ser humano, al comprenderse y comprender a otra persona mediante el conocimiento profundo del caso concreto, puede perdonar auténticamente y renunciar a su riguroso castigo. A ello se arriba, en términos de Séneca, a través de la clemencia (clementia), la que definió como “...una inclinación del alma a la benignidad en la imposición de castigos...." ${ }^{105}$

En conclusión, es innegable que a través de la ira es posible que se expresen los rasgos más notables de la violencia humana, porque la ira puede implicar cierto disfrute en el sufrimiento ajeno y una suerte de deseo de venganza, circunstancia que crea una distancia del ser humano consigo mismo y con sus congéneres. Pero, por otra parte, la posición neutral o indiferente ante hechos horrorosos puede indicar también cierto distanciamiento frente lo humano en otro sentido, ya que no indignarse ante hechos aberrantes implicaría también una falta de compromiso con la dignidad humana que ha sido lesionada.

Estimo que los argumentos estoicos tendientes a suavizar las relaciones humanas y a protegerlas de la ira a través de la clemencia resultan insostenibles en el caso de los hechos horrendos que afectan a la humanidad, como son los crímenes de guerra, de lesa humanidad, genocidios y femicidios, puesto que somos parte de esa humanidad menoscabada y no debemos ignorar que el sufrimiento de otros debería ser también el nuestro. Por eso cierro esta sección recordando la sentencia aristotélica, que dice: "debemos irritarnos con ciertas cosas... las pasiones irracionales no parecen menos humanas, de modo que también las acciones que proceden de la ira y del apetito son propias del hombre, $y$ es absurdo considerarlas como

105 Nussbaum, La terapia del deseo..., obra citada, en alusión a De Clementia, de Séneca, p. 526. 
involuntarias". ${ }^{106}$

En el punto siguiente me ocuparé de explorar el papel que las emociones morales juegan en los procesos judiciales de los sistemas que han incorporado las prácticas sociales restaurativas.

\subsection{Emociones morales y justicia restaurativa:}

En la década de los setenta surgió en distintos países del mundo y en el contexto de la criminología una corriente de justicia denominada "Justicia Social Restaurativa", con el objetivo de "reparar el daño causado a las personas y a las relaciones más que castigar a los delincuentes". ${ }^{107}$ Esta corriente reapareció en la década de los noventa como un proceso de subsanación que incluyó a las víctimas indirectas, esto es a familiares, amistades de las víctimas y sus comunidades de apoyo $\mathrm{y}$, también, a las personas que presuntamente delinquieron. Me extenderé sobre esta propuesta porque en las prácticas sociales restaurativas, que implican un proceso de reconciliación, perdón y arrepentimiento, están claramente involucradas las emociones morales.

En un artículo del año 2000: "The Origins of Restorative Justice", ${ }^{108}$ May Leung explicaba que en el año 1989, el gobierno de Nueva Zelanda implementó principios de justicia social restaurativa para la resolución de conflictos en los asuntos de niñez, juventud y familia, recogiendo la experiencia ancestral de la tradición Maorí. Esta iniciativa fue luego puesta en práctica por el gobierno de Australia -para asuntos de familia- y en 1996 por la Corte de Justicia en lo Correccional de Canadá, como una respuesta a la comunidad sobre asuntos criminales, y en 1998 se extendió a los conflictos civiles.

Es interesante advertir, como refiere May Leung, que el origen del movimiento social restaurativo de Canadá proviene de las prácticas judiciales de los pueblos originarios, que incluyen un involucramiento físico y espiritual de

\footnotetext{
106 Aristóteles, EN, obra citada, 1111a.

107 McCold, P. y Watchel, T., "En busca de un paradigma: una teoría sobre justicia restaurativa", ponencia presentada en el XIII Congreso Mundial de Criminología, 12 de agosto de 2003, publicada en Internet por el International Institute for Restorative Practices en: www.restorativepractices.org

${ }^{108}$ Leung, May, "The Origins of Restorative Justice”, premio "Resolución de Conflictos", publicado en el año 2000, por el Departamento de Justicia de Canadá en: http://cfcj-fcjc.org/clearinghouse/drpapers/leung.htm
} 
las partes en la resolución del conflicto. También han tenido influencia ciertos valores cristianos y, en particular, las prácticas de la comunidad Menonita.

Leung contrasta los pilares de la justicia ordinaria contemporánea con los de la justicia bíblica del Antiguo Testamento, señalando que esta última establece un principio de justicia holístico, cimentado en la responsabilidad y no en la culpa, en cuyo contexto la punición es una redención y no un fin en si mismo, como sucede con los sistemas actuales de justicia criminal que fundados en el retribucionismo buscan dividir a la sociedad más que velar por su unidad; dice Leung:

"La justicia retributiva parte de la premisa de que justicia significa distribución del castigo... Desde esa perspectiva, los victimarios no merecen el amor y la misericordia de otros. Aunque se reconoce que la justicia [retributiva] basada en "ojo por ojo" juega algún rol en la sociedad, la Biblia demuestra un claro rechazo a tal enfoque de la justicia, porque Dios y Jesús otorgan de acuerdo a la necesidad y no al mérito, y la justicia se mide por "reglas de derecho que se aplican en el sentido correcto". En lugar de ello, se calcula si el resultado sirvió para restaurar... mejorando o corrigiendo la situación. Entonces, los conceptos de restitución, arrepentimiento y satisfacción, son más importantes que los de retribución y punición en la justicia Bíblica... la restauración asegura que el castigo no sea un fin en si mismo, sino más bien la restauración o "vindicación" del oprimido. En realidad, todas las normas bíblicas están concebidas para mejorar la sociedad, más que como un fin en sí mismas. La ley es "un instrumento para construir paz, para la construcción de relaciones correctas" y "su propósito no es castigar, sino redimir, hacer las cosas correctas". A diferencia del sistema judicial moderno, la justicia Bíblica mira hacia el futuro, y hacia el pasado." 109

La finalidad las "prácticas restaurativas" consiste, pues, en ofrecer un marco de contención compartido entre personas víctimas y victimarias, que les permita expresar sus "sentimientos", describir cómo el daño afectó sus vidas, reflexionar sobre el comportamiento desplegado que derivó en un acto lesivo y elaborar conjuntamente un plan de reparación para evitar nuevos daños:

"Todas las partes interesadas necesitan una oportunidad para expresar sus sentimientos y participar en la decisión sobre la manera de reparar el daño. Las víctimas se ven perjudicadas por la pérdida de control que sufren como consecuencia del delito. Necesitan recuperar un sentido de dominio personal. Esta obtención de control personal es lo que transforma a las víctimas en sobrevivientes. Los delincuentes dañan sus relaciones con sus propias comunidades de apoyo traicionando la

${ }^{109}$ Leung, May, obra citada. 
confianza. Para recobrar esa confianza necesitan tener control personal para asumir la responsabilidad por el delito cometido... las partes interesadas primarias deciden por ellas mismas el resultado del caso...".110

En consecuencia, podemos observar que la justicia social restaurativa surgió como una alternativa al modelo de punición retributiva, buscando fortalecer la dignidad humana en las víctimas y propiciar un clima de diálogo y participación activa de todas las partes involucradas en un conflicto que les permita expresar sus emociones morales y asumir públicamente la responsabilidad por los actos causados.

\subsubsection{Conflictos emocionales y prácticas sociales restaurativas:}

Las prácticas restaurativas que emergieron en el seno de la justicia penal se fueron extendiendo a otras áreas de la justicia en las que también se plantean conflictos emocionales, como aquellas relacionadas con los asuntos de familia y con los daños y perjuicios, incluso posteriormente fueron implementadas en los procesos en los que el conflicto se daba entre particulares y el estado por graves violaciones a los derechos humanos, como fue el caso del establecimiento de una Comisión por la Verdad y la Reconciliación en Sudáfrica.

En el contexto del derecho internacional, la Justicia Social Restaurativa adquirió preponderancia en el $10^{\circ}$ Congreso de las $\mathrm{N}$ aciones Unidas sobre Prevención del Delito y Tratamiento del Delincuente, celebrado en Viena, del 10 al 17 de abril del 2000, mediante la Declaración de Viena sobre la Delincuencia y la Justicia: Frente a los Retos del siglo $X X I,{ }^{111}$ en la que se propició la: “...elaboración de políticas, procedimientos y programas de justicia restitutiva que respeten los derechos, necesidades e intereses de las víctimas, los delincuentes, las comunidades y demás partes interesadas..."112 y se instó a los estados a revisar sus "prácticas judiciales" antes del año 2002.

En su $11^{\circ}$ período de sesiones, dado entre el 16 y el 25 de abril de 2002, la Comisión de Prevención del Delito y Justicia Penal del Consejo Económico y Social de las Naciones Unidas debatió sobre la reforma del sistema penal en

\footnotetext{
110 McCold, P., obra citada, p. 3. 
términos de eficacia y equidad y el Grupo de Expertos sobre Justicia Restaurativa produjo un informe en el que se señaló, entre otras cosas, que:

"Las formas tradicionales y autóctonas de justicia consideraban fundamentalmente que el delito era un daño que se hacía a las personas y que la justicia restablecía la armonía social ayudando a las víctimas, los delincuentes y las comunidades a cicatrizar las heridas." "13

En dicho documento se indicaba que, en un nivel procesal, las prácticas restaurativas reexaminaban la condición jurídica y el rol de las víctimas en los procesos judiciales; por cuanto la tendencia en muchos sistemas de justicia penal observados consistía en "considerar los procedimientos penales como un proceso antagónico entre el Estado y el delincuente en el que la víctima sólo tenía, eventualmente, la condición de testigo". ${ }^{114}$ Hubo consenso en sostener que este tipo de prácticas debían ser complementarias al sistema de justicia penal ordinario, y que los principios en que se basaran debían guardar coherencia con los del sistema vigente, destacándose que la justicia social restaurativa no debía convertirse en un sistema paralelo.

En el preámbulo de su "Anexo" se resaltaba que la justicia restaurativa, entendida como una respuesta evolutiva al delito, debía respetar la dignidad e igualdad de todas las personas involucradas, favoreciendo el mutuo entendimiento y promoviendo la armonía social; otorgar a las víctimas la posibilidad de obtener una reparación por el daño, a las personas victimarias la oportunidad de comprender las causas y efectos de su comportamiento para asumir una genuina responsabilidad por los hechos y a los estados el derecho de enjuiciar a quienes presuntamente hayan perpetrado un crímen. Un hecho destacable es que tanto las víctimas como las personas denunciadas como victimarias deben prestar su consentimiento para participar de procesos restaurativos, sin que ello implique, para estas últimas, prima facie, asunción de responsabilidad.

"Acciones contra el crimen organizado y el terrorismo" fueron los principales tópicos abordados en el $11^{\circ}$ Congreso para la prevención del

\footnotetext{
${ }^{113}$ E/CN.15/2002/5/Add.1, párrafo 15.
}

${ }^{114}$ E/CN.15/2002/5/Add.1, párrafo 16. 
Crimen y la Justicia Criminal, llevado a cabo en Bangkok, entre el 18 y el 25 de abril de 2005, que abarcó las siguientes temáticas: tráfico humano, lavado de dinero, corrupción, ciber-crimen y Justicia Restaurativa. ${ }^{115}$

En el año 2006, la Oficina de Drogas y Crimen de las Naciones Unidas, con sede en Viena, Austria, preparó un documento para la incorporación de leyes y programas de Justicia Restaurativa en los estados, como un marco de referencia para las futuras reformas de los sistemas criminales actuales. ${ }^{116} \mathrm{En}$ dicho documento quedó plasmado que la Justicia Restaurativa es un proceso de carácter inclusivo, por cuanto todas las partes afectadas, directa e indirectamente, tienen derecho a participar de la solución del problema; resaltándose que el comportamiento llevado a cabo por la persona que perpetró el delito no solamente viola la ley, sino que también causa una ofensa a la víctima y a la comunidad. Estableció los siguientes objetivos para llevar a cabo prácticas restaurativas: restaurar el orden y la paz de la comunidad y reestablecer los vínculos afectados; denunciar como inaceptable el comportamiento criminal reafirmando los valores de la comunidad; apoyar a las victimas para que hablen y participen activamente; animar a todas las partes a asumir su responsabilidad, especialmente a las personas ofensoras para que tomen consciencia de las consecuencias de sus actos; dar un sentido positivo y próspero a la restauración: la restauración no buscará castigar sino reparar significativamente el daño; reducir la reincidencia alentando a las personas ofensoras a efectuar un cambio interno que facilite su reintegro social $y$, finalmente, identificar los factores que motivaron el crimen. La restauración comienza con la franqueza de espíritu en el diálogo, dejando de lado las excusas.

De acuerdo con las experiencias obtenidas por los estados, reportadas a la Oficina de Drogas y Crimen de las Naciones Unidas, se identificaron las siguientes modalidades restaurativas:

la mediación entre víctima y victimario/a, también conocida como programas de reconciliación. El documento cita como ejemplo el

\footnotetext{
115 Toda la información se encuentra en: www.un.org/events/11thcongress/

116 United Nation Office on Drugs and Crime, Handbook On Restorative Justice Programmes, New York: 2006, United Nation Publications, Criminal Justice Handbook Series.
} 
"Programa prejudicial de Libertad Condicional" que funciona en la república Checa;

- las conferencias comunitarias o en grupos familiares, que tuvieron origen en 1989 con las prácticas de los maoríes en Nueva Zelanda y que se aplican actualmente en el sur de Australia, Sudáfrica, Irlanda y en los estados de Montana, Minnesota y Pennsylvania, Estados Unidos;

- los círculos de sentencias, que proceden de las prácticas de comunidades aborígenes de Canadá, que se caracterizan porque todas las personas que participan del proceso, operadores y auxiliares de justicia, víctimas, victimario/a, familiares y personas de la comunidad se sientan en círculo, cara a cara, para discutir sobre el conflicto y consensuar un acuerdo. Se considera que el hecho criminal es un episodio inmerso en una dinámica social conflictiva, que la sentencia es una parte pequeña de la solución del problema, que el foco está en el presente y en la futura conducta de la persona ofensora, la perspectiva es holística, lo importante no es el resultado, esto es la sentencia, sino el proceso, esto es que todas las partes de la relación se sanen y lo más relevante es el rol que asume la comunidad por su participación en la solución del problema;

- los círculos de paz, que surgieron en 1997 en Zwelethemba, Sudáfrica, que establecen guías para la construcción de la paz o solución pacífica de los conflictos, antes que reglas, y que mediante la restauración buscan restituir, perdonar y compensar; y

los programas de libertad condicional reparativa, que se aplicaron en países como Brasil, Inglaterra y Estados Unidos, en la década del noventa, principalmente para los procesos de justicia criminal juvenil e incluso, extrajudicialmente se implementaron en las escuelas para facilitar la respuesta a hechos de vandalismo escolar, peleas entre "pandillas", intimidación violenta o bullying y extorsión a menores. ${ }^{117}$

La Corte Constitucional de Colombia en la sentencia C-979/05, al tratar los límites del poder punitivo del estado garantizados por los principios constitucionales de cosa juzgada y non bis in ídem, estableció el carácter relativo de los mismos al entender que:

"no pueden ser oponibles válidamente en un asunto que envuelve un acto de intolerable injusticia... Las mismas cautelas que en su momento tuvo la Corte para autorizar la posibilidad de que por la vía de la revisión penal extraordinaria, se reabrieran procesos por violaciones de derechos humanos, que había culminado con una decisión favorable al sentenciado, con ruptura del principio del non bis in ídem, operan en el caso de la reapertura de procesos culminados con sentencia condenatoria... la reapertura se produce a través de un mecanismo

117 United Nation Office on Drugs and Crime, Handbook..., obra citada, pp. 13-29. 
procesal extraordinario, opera para la criminalidad con mayor potencialidad ofensiva y desestabilizadora como son los crímenes contra los derechos humanos y el derecho internacional humanitario, $y$ está condicionada al pronunciamiento de una instancia internacional acerca del incumplimiento del Estado de sus obligaciones de investigación y sanción de estos crímenes..."118

En dicho acto judicial, la Corte se expidió sobre la constitucionalidad de las prácticas judiciales restaurativas incorporadas en el código procesal penal de ese estado. Ese máximo tribunal estimó que la justicia social restaurativa surgió como una respuesta alternativa a las profundas inequidades que plantea la disfuncionalidad del sistema penal actual:

\begin{abstract}
“...aunque su planteamiento aparece asociado a movimientos que involucran una crítica al carácter represivo y retributivo del derecho penal, y a la patente ineficacia del sistema, sus fuentes menos inmediatas se encuentran en teorías y procesos de contenidos diversos que transitan por lo religioso, lo cultural y lo ético. La justicia restaurativa se presenta como un modelo alternativo de enfrentamiento de la criminalidad, que sustituye la idea tradicional de retribución o castigo, por una visión que rescata la importancia que tiene para la sociedad la reconstrucción de las relaciones entre víctima y victimario. El centro de gravedad del derecho penal ya no lo constituiría el acto delictivo y el infractor, sino que involucraría una especial consideración a la víctima y al daño que le fue inferido. Conforme a este modelo, la respuesta al fenómeno de la criminalidad, debe diversificar las finalidades del sistema. Debe estar orientada a la satisfacción de los intereses de las víctimas (reconocer su sufrimiento, repararle el daño inferido y restaurarla en su dignidad), al restablecimiento de la paz social, y a la reincorporación del infractor a la comunidad a fin de restablecer los lazos sociales quebrantados por el delito, replanteando el concepto de castigo retributivo que resulta insuficiente para el restablecimiento de la convivencia social pacífica." ${ }^{119}$
\end{abstract}

Ante un planteo concreto de constitucionalidad de dichas prácticas restaurativas, la Corte Constitucional de Colombia no sólo rescató su valor interno sino que, con dicho pronunciamiento, colaboró con la evolución del derecho penal internacional en torno al concepto y alcance de la justicia social restaurativa, en contraste con el clásico enfoque retributivo de punición estatal.

Las prácticas sociales restaurativas descriptas han recibido críticas de

\footnotetext{
118 Ver Sentencia C-979/05, dictada en Bogotá, Colombia, en fecha 26 de septiembre de 2005, recaída en el expediente D-5590 "Demanda de inconstitucionalidad contra los artículos 78, 192, 327, 330 y 527 de la Ley 906 de 2004 Actor: Rodrigo Paz Mahecha y otros”, magistrado ponente: Dr. Jaime Córdoba Tribiño.

119 C-979/05.
} 
autores tales como Ronald Cohen, quien en "Provocation of Restorative Justice" explicaba que la justicia social restaurativa tiene tres instancias bien claras: 1) la identificación de los actores: ofensor/a, víctima/s y comunidad; 2) un examen de las prácticas que dieron lugar a la injusticia creada que los convoca; y 3) el establecimiento de un foro público de encuentro para la expresión de emociones que sea válido y apropiado. Según Cohen, la identificación de las partes comprometidas puede resultar problemática y, aún siendo identificadas, puede resultar provocativo un encuentro "cara a cara" entre personas victimas y victimarias. ${ }^{120}$

Cohen también ha argumentado que sólo las partes directas pueden darle un significado válido a las prácticas restaurativas. Arguye que si bien es posible que se disculpen o perdonen mutuamente, también es factible que consideren que la participación de terceras personas, como amistades, familiares y terceros, pueda llegar a distorsionar el significado de los hechos, obstaculizando la resolución del caso.

Finalmente, cuestiona el Cohen el rol de las prácticas sociales restaurativas en torno a la resolución de profundas injusticias estructurales, como ser el hambre y el racismo. El autor advierte que dichas practicas, aún cuando han sido diseñadas para el reestablecimiento de la paz y la reparación del daño mediante la restauración de los vínculos afectados, pueden tener obstáculos iniciales que ahonden más las heridas causadas o profundicen un sentimiento de injusticia en casos de desigualdades bien marcadas. Sin embargo, como veremos a continuación, las practicas sociales restaurativas están conducidas por un proceso de transformación personal de todas las partes, directa e indirectamente implicadas en el juicio, que incluye arrepentirse, reconciliarse y perdonar el pasado; proceso que en sociedades democráticas e inclusivas, como es el caso de Canadá, redunda en un constante progreso social en términos de conciencia por los daños materiales y morales causados.

\subsubsection{Arrepentimiento, perdón y reconciliación:}

${ }^{120}$ Cohen, R. L., "Provocation of Restorative Justice", en Social Justice Research, Vol. 14, Nro. 2, Junio de 2001, pp. 209-232. 
Los elementos característicos de las prácticas de justicia social restaurativa son las expresiones de arrepentimiento de las personas ofensoras y de perdón de las víctimas. En los sistemas judiciales donde las prácticas restaurativas se encuentran actualmente funcionando, se prepara y estimula tanto a quien delinquió para que logre arrepentirse sinceramente, como a las víctimas para que logren perdonar a sus victimarios, ello sin perjuicio de otras medidas que sean atinentes aplicar en función de las responsabilidades jurídicas. Las prácticas sociales restaurativas, entonces, funcionan como un espacio de reconsideración de los hechos, de reconocimiento de responsabilidad y de cambio interior en cada una las partes.

En un ensayo publicado en septiembre de 2009, Ari Kohen argumentaba en contra de la percepción común y de la posición de autores como Howard Zher, ${ }^{121}$ que el perdón no es necesariamente un concepto religioso, pero es efectivamente un componente fundacional de la justicia social restaurativa. ${ }^{122}$ Observando la experiencia de las prácticas sociales restaurativas implementadas por Nelson Mandela en Sudáfrica, Kohen distinguió el perdón de la reconciliación, y dentro de ésta última estableció dos tipos: la reconciliación política y la personal. Para el autor, la reconciliación es un objetivo de dichas prácticas que siempre yace en un ánimo de perdonar el pasado; independientemente de que la reconciliación sea personal, entre las partes, o política entre víctimas y los estados responsables de las violaciones a los derechos humanos.

Según Kohen son cuatro las "necesidades" que atiende la justicia social restaurativa respecto de las víctimas, esto es: información real, relato verdadero, empoderamiento y restitución, y agrega que “...es a través de la experiencia de perdonar a quien ofendió que la víctima se empodera y puede acceder a todo lo que el proceso restaurativo le ofrece...". 123

\footnotetext{
${ }^{121}$ Howard Zehr es profesor del Centro por la Justicia y la construcción de la Paz de la Universidad Menonita del Este, ubicada en Harrisonburg, Virginia, Estados Unidos. Su obra más conocida es The Little Book of Restorative Justice, publicada en el año 2002. Ver información publicada por el autor: http://emu.edu/blog/restorative-justice/

${ }^{122}$ Kohen, A., "The personal and the political: forgiveness and reconciliation in restorative justice", en Critical Review of International Social and Political Philosophy, Vol. 12, No. 3, 2009, pp. 399-423.

${ }^{123}$ Kohen, A., “The personal...”, obra citada, p. 401.
} 
El autor explora el concepto de perdón del Nuevo Testamento, que obra en el pasaje de Mateo: 18: 21-22, las definiciones provistas por el Diccionario Inglés Oxford y la interpretación del perdón secular realizada por Hannah Arendt en La Condición Humana (1958) y efectúa un análisis de las relaciones de poder que se dan entre personas víctimas y victimarias, sosteniendo que la ofensa convierte a la víctima en objeto, en cosa, anulando su autonomía personal; autonomía que según el autor se recobra en la experiencia de justicia social restaurativa. El perdón, entonces, actuaría liberando a la víctima de resentimiento, "dejando ir" la ofensa, al mismo tiempo que cicatrizaría sus heridas. $^{124}$

Recordemos que para Arendt el perdón es una acción -alternativa al castigo- que "sirve para deshacer los actos del pasado"125, mientras que la venganza es una reacción:

“...el perdón es el extremo opuesto a la venganza, que actúa en forma de reacción contra el pecado original, por lo que en lugar de poner fin a las consecuencias de la falta, el individuo permanece sujeto al proceso, permitiendo que la reacción en cadena contenida en toda acción siga su curso libre de todo obstáculo. En contraste con la venganza,... el acto de perdonar no puede predecirse..., perdonar es la única reacción que no re-actúa simplemente, sino que actúa de nuevo y de forma inesperada, no condicionada por el acto que la provocó y por lo tanto libre de sus consecuencias, lo mismo quien perdona que aquel que es perdonado." 126

Según piensa Arendt, perdonar o castigar son acciones tendientes a poner fin al asunto, mientras que vengar es una acción reactiva, calculada y autodestructiva: "Por lo tanto es muy significativo, elemento estructural en la esfera de los asuntos públicos, que los hombres sean incapaces de perdonar lo que no pueden castigar e incapaces de castigar lo que ha resultado ser imperdonable. Ésta es la verdadera marca de contraste de esas ofensas que, desde Kant, llamamos «mal radical»...". ${ }^{127}$ Arendt considera que al perdonar se establece un vínculo personal con los hechos y sujetos, objeto de perdón, y que sólo el amor por su carácter desinteresado y extramundano tiene un

\footnotetext{
124 Ibíd., p. 404.

125 Hanna Arendt, La Condición Humana, traducción de Ramón Gil Novales, Buenos Aires: Paidós, 3ra. reimpresión, 2007, p. 256.

126 Arendt, H., La Condición..., obra citada, p. 260.

127 Arendt, H., La Condición..., obra citada, p. 260.
} 
“...inigualado poder de autorrevelación y una inigualada claridad de visión...," ${ }^{128}$ para poder perdonar.

Arendt cuestiona el poder divino que se le adjudica al amor, propio de la visión cristiana, porque a su entender si sólo pudiéramos perdonar por obra de Dios, entonces la acción de perdonar sólo sería divina y no humana. Arendt cree que Jesús de Nazaret fue el descubridor del lugar que tiene el perdón entre los seres humanos, aunque, obviamente, sólo se ocupó de hacerlo bajo un discurso religioso. Sostiene la autora que:

"...lo que es el amor en su propio respeto... se halla en el más amplio dominio de los asuntos humanos. El respeto... es una especie de "amistad» sin intimidad ni proximidad, es una consideración hacia la persona desde la distancia que pone entre nosotros el espacio del mundo, y esta consideración es independiente de las cualidades que admiramos... En todo caso, el respeto debido a que sólo concierne a la persona, es totalmente suficiente para impulsar lo que hizo la persona, por amor a la persona...." ${ }^{129}$

De su lectura se desprende que, como consecuencia del respeto y consideración hacia otro ser humano, el amor se nos revela en la experiencia intersubjetiva aportándonos claridad sobre esa persona y sobre esos hechos para así estar en condiciones de perdonar con justicia.

Ari Kohen fue uno de los autores que avanzó en el análisis acerca de la dificultad que representa poder perdonar en los procesos de justicia ordinarios, basados en un sistema de retribución punitiva. En efecto, según el autor en tales juicios el estado es el principal adversario del crimen, y las víctimas quedan desplazadas y pierden poder. Incluso, dice Kohen que en los estados en los que aún persiste la pena capital las víctimas -aunque perdonen a sus ofensores y apelen a la compasión del tribunal para evitar ese tipo de medidas duras- corren el riesgo de ser multadas. ${ }^{130}$

Por otro lado, es necesario tener en cuenta, como el mismo Kohen sostiene, que la reconciliación se da en un plano distinto al perdón siendo por lo tanto ambos conceptos: reconciliación y perdón, separables entre sí. El supuesto de la reconciliación personal es factible cuando hay una relación

\footnotetext{
128 Arendt, H., La Condición..., obra citada, p. 261.

${ }^{129}$ Ibíd., p. 262.

${ }^{130}$ Kohen, A., "The personal...", obra citada p. 406.
} 
previa que reestablecer, puesto que la restauración del vínculo pacífico constituiría una prioridad para ambas partes, pero cuando se trata de personas extrañas y no vinculadas, que lo único que los vincula es el crimen cometido, entonces las posibilidades de reconciliación son más remotas. Sin embargo, en este último supuesto, resalta el autor que los programas de reconciliación restaurativa son óptimos para arribar a este objetivo que la justicia ordinaria no puede cubrir. Para Kohen, la reconciliación personal en los procesos restaurativos implica por parte de la persona ofensora la asunción de su responsabilidad por el daño causado y la expresión de su arrepentimiento ante la víctima.

En relación con la reconciliación política, Ari Kohen cita el ejemplo de la Comisión por la Reconciliación y la Verdad de Sudáfrica, en la que se veló por la unidad nacional con el objetivo de dejar atrás emociones morales vindicativas tales como el odio, el temor, la culpa y la revancha, todo ello en base a lo que los sudafricanos conocen tradicionalmente como filosofía ubuntu.

En una carta dirigida a la comunidad de Steve Tshwete, el 17 de noviembre de 2006, la entonces presidenta de Sudáfrica, Phumzile MlamboNgcuka, explicó que ubuntu es lo que distingue al espíritu humanista de los africanos; es la base política de la constitución africana para la cohesión social, cuyos valores son: el cuidado de la humanidad, el amor hacia todas las personas del pueblo africano y el respeto por otras personas y sus estados. La presidenta sostuvo que ubuntu alude al espíritu social, a la memoria ancestral y conciencia colectiva de la existencia de unos seres humanos en dependencia con la de otros: "...abrir el corazón a los más necesitados, a los pobres, no es un signo de debilidad sino de fortaleza que ubuntu... nos infunde...". 131

En "Perdón y Reconciliación Política: dos medidas restaurativas para enfrentar el pasado", Camila de Gamboa Tapias arguye que el perdón es un poder moral que concierne sólo a la víctima y que, por lo tanto, ningún estado puede forzar su concesión. ${ }^{132}$ Aclara que la reconciliación política es una

\footnotetext{
131 Ver: http://www.info.gov.za/speeches/2006/06112910451005.htm

132 Camila de Gamboa Tapias, "Perdón y Reconciliación Política: dos medidas restaurativas para enfrentar el pasado", en Revista Estudios Socio-Jurídicos, Universidad del Rosario, Bogotá, Colombia: enero/junio, 2004, Vol. 6, Nro. 1, pp. 81-110.
} 
medida pública para enfrentar un pasado político opresivo e injusto, que concierne a toda la comunidad. Para Gamboa Tapias, tanto el perdón como la reconciliación como modelos de restauración de justicia social deben darse en el marco de sociedades democráticas e inclusivas en las que se garantice el respeto igualitario de personas víctimas y victimarias, porque según ella: “...cuando los modelos reconciliatorios no son incluyentes y no respetan la igualdad de las personas en un sentido moral y político, se construyen modelos de reconciliación que no respetan el pasado y la naturaleza colectiva de la violencia y la opresión...". ${ }^{133}$ Creo que este punto es muy importante.

La autora critica, y coincido con ella, los modelos de reconciliación política que fuerzan a las víctimas a perdonar a sus ofensores, porque atentan contra el principio constitucional de autonomía personal y se inmiscuyen en la esfera de acción privada de sus ciudadanos: "Esta condición... constituiría una intromisión indebida por parte del Estado en relación con un poder moral que únicamente pertenece a la víctima...". ${ }^{134}$ Lo importante en el análisis de Gamboa Tapias es, además, el modo como explica que las ofensas afectan la autoestima de las víctimas y cómo el alto o bajo nivel de autoestima en ellas determina un alto o bajo nivel de resentimiento; resentimiento que funciona como variable para perdonar sin agredir, o para aumentar la agresión. Dice:

“...las únicas situaciones en las que el perdón puede ser considerado apropiado, moralmente hablando, son aquellas en las cuales los individuos ofendidos pueden estar seguros de que al perdonar no están vulnerando su valor como seres morales... es el caso del sincero arrepentimiento, pues en este evento particular el ofensor se comporta como un agente responsable $y$, por eso, el ofendido puede estar seguro...". ${ }^{135}$

En síntesis, según la autora el arrepentimiento sincero tiene dos aspectos que le son constitutivos: el proceso de auto transformación personal, en el que la persona victimaria juzga sus propias acciones como reprochables y acepta su responsabilidad, y el proceso de interacción con la víctima consistente en prometerle no repetir tal acción, eso es, de auto-corregirse. El proceso de perdonar también es descripto por ella en dos etapas: la primera

\footnotetext{
133 De Gamboa Tapias, C., “Perdón y Reconciliación...”, obra citada, p. 83.

134 Ibíd., p. 86.

135 Ibíd., p. 89.
} 
consistente en la preparación psicológica de la víctima, para que logre mirar a la persona ofensora sin resentimiento, recobrando de tal modo confianza en sí misma, y la segunda etapa constituida por el acto concreto de perdonarla voluntariamente; acto que de Gamboa Tapias califica como virtuoso: “...El perdón constituye un acto de benevolencia por parte del ofendido, quien libera al ofensor de su pasado, con la creencia de que éste cambiará y se convertirá en un ser humano mejor...". 136

Para su definición de reconciliación política la autora emplea como marco normativo distintas nociones : 1) la de "democracia inclusiva" como modelo a seguir por los estados en transición hacia la democracia, en contraposición a la exclusión, por medio de la opresión social, que han generado y aún generan las dictaduras; 2) el concepto de "suerte moral", que alude a las circunstancias sociopolíticas de una sociedad que impactan sobre las decisiones de los individuos que las componen y, finalmente, 3) al concepto de "toma de responsabilidad" individual, colectiva, política y criminal respecto de los hechos de injusticia y violencia ocurridos en la sociedad.

Es importante señalar, por otro lado, que la responsabilidad política, según de Gamboa Tapias, atañe a toda la comunidad y se refiere a: “...la obligación particular de recordar su historia de injusticia y sufrimiento... cuando uno acepta el estatus político ciudadano, a su vez acepta la identidad histórica de esa comunidad y el compromiso ético político de actuar como miembro responsable de ésta...". 137 Aclara la autora que la responsabilidad política tiene que ver con el compromiso ético de toda la ciudadanía de enjuiciar a quienes hayan causado los hechos criminales de conformidad con los principios constitucionales propios de una democracia inclusiva. Respecto de la responsabilidad moral individual, la autora sostiene que la misma se asume en sintonía con la responsabilidad política colectiva:

"Una democracia transicional tiene que crear una atmósfera favorable para lograr que los miembros de la sociedad se transformen personal y políticamente... es necesario entonces que el proceso de reconciliación cree unas medidas públicas que expongan la inhumanidad e injusticia de esas tradiciones e instituciones... estos remedios deben servir para

\footnotetext{
136 Ibíd., p. 91.

137 Ibíd., p. 95.
} 
que los individuos tomen conciencia de sus acciones y al mismo tiempo entiendan la conexión cercana que existe entre sus convicciones personales, la opresión y la violencia política...". ${ }^{138}$

Por último, la autora analiza tres perspectivas con las que usualmente abordan los estados la reconciliación política: las políticas públicas de perdón y olvido basadas en amnistías; las prácticas judiciales de crimen y castigo; y las prácticas judiciales restaurativas. La autora critica las políticas globales de amnistía argumentando, de manera correcta, que al negar el sufrimiento de las víctimas niegan también la agencia moral de sus ciudadanos excluyéndolos de la justicia, al mismo tiempo que jerarquizan a las personas violadoras de los derechos humanos, impidiéndoles que tomen real consciencia sobre el alcance de sus actos criminales.

En torno a las prácticas judiciales de "crimen y castigo" seguidas contra quienes hayan violado derechos humanos, de Gamboa Tapias considera que al producirse usualmente la retención de poder político por parte de algunos de ellos, se dificulta su posterior judicialización criminal y encarcelamiento. Por otra parte, revela que los estados que acuden a criterios de selección de enjuiciamiento criminal, en virtud de la gran cantidad de perpetradores y la baja capacidad burocrática de respuesta judicial, derivan en el enjuiciamiento de "unos pocos" dejando de lado: “...las tradiciones opresivas y valores que han distorsionado la agencia moral de tales miembros, y la responsabilidad moral y política de todos aquellos que componen la sociedad...". ${ }^{139}$

Para concluir, la autora agrega que las prácticas sociales restaurativas deben indagar sobre el origen histórico de la violencia política, además de buscar la verdad sobre los hechos, en función de los testimonios de las víctimas y del reconocimiento de las violaciones a los derechos humanos por parte de las personas ofensoras; siendo también relevante el establecimiento de reparaciones materiales y aquellas de orden simbólico, como son las disculpas públicas.

Ahora bien, antes de terminar con este punto es preciso advertir que la justicia social restaurativa no debe confundirse con el modelo de justicia

\footnotetext{
138 Ibíd., p. 97.

${ }^{139}$ Ibíd., p. 101.
} 
transicional, que ha tenido y tiene lugar luego de conflictos armados de carácter interno o internacional, en los que se han verificado sistemáticas y graves violaciones a los derechos humanos. La justicia transicional busca tanto el restablecimiento de la democracia como la pacificación de las relaciones entre sectores de la población o grupos paramilitares y el estado al que pertenecen, o, entre los distintos estados implicados en un conflicto de orden internacional.

Aunque algunos modelos de transición, de la guerra hacia la paz o de la dictadura a la democracia incluyen prácticas sociales restaurativas -como el caso de la Comisión por la Reconciliación y la Verdad en Sudáfrica- la mayoría de ellos consisten en un proceso de desmilitarización o pacificación social mediante la identificación, indagación, imputación y adjudicación de responsabilidad a las personas que hayan cometido graves y masivas violaciones a los derechos humanos.

Un ejemplo paradigmático de justicia transicional en Latinoamérica, que no tiene componentes restaurativos, es la Ley 975 de Justicia y Paz de Colombia, que por cierto ha recibido críticas desde distintos sectores. La Comisión Interamericana de Derechos Humanos, en su comunicado de prensa de fecha 15 de julio de 2005, se pronunció en relación a la aprobación de la Ley de Justicia y Paz en Colombia, cuyo objetivo central fue establecer un diálogo pacífico entre el gobierno y los grupos armados paramilitares involucrados en graves violaciones a los derechos humanos en el marco del conflicto armado, para lograr su desmovilización. ${ }^{140}$ La CIDH observó que la ley no contemplaba entre sus objetivos arribar a la verdad histórica sobre el suceso, ni avanzar en el grado de responsabilidad (acción, omisión, colaboración, aquiescencia) de las personas involucradas en crímenes cometidos contra la población civil. Criticó el mecanismo previsto sosteniendo que al no indagar sobre la verdad y el esclarecimiento de los hechos, mantenía la impunidad y favorecía “...el ocultamiento de otras conductas que una vez

\footnotetext{
140 Para profundizar sobre el cumplimiento del objetivo de desmovilización colombiano legalmente propuesto se puede consultar el Informe 481/3 producido por la Federación Internacional de Derechos Humanos en Octubre de 2007, en el que Souhayr Belhassen, su presidenta, expresó que se pudo constatar con severidad que "la búsqueda de verdad, de justicia y de reparación conduce a numerosas frustraciones y, en definitiva, a una especie de doble victimización" y resaltó que más de 80.000 víctimas manifestaron su voluntad de participar en los procesos, indicando ello una profunda esperanza al mismo tiempo que una gran responsabilidad para las autoridades.
} 
descubiertas podrían ser objeto del mismo beneficio de penas alternativas en el futuro...". ${ }^{141}$ Mantuvo que los cortos plazos establecidos no ofrecían una alternativa realista para establecer responsabilidades individuales, y señaló que al poner su énfasis en la restitución de bienes adquiridos ilícitamente las reparaciones a las víctimas no resultaban integrales, y que ni siquiera se mencionaba el daño particularmente ocasionado a los pueblos originarios y afro descendientes y a las mujeres desplazadas, jefas de hogar. Finalmente, la $\mathrm{CIDH}$ criticó la falta de mecanismos de no repetición de esos crímenes en el texto normativo, como garantía para la paz y seguridad humana.

Hecha esta aclaración respecto de la justicia transicional, analizaré ahora muy brevemente en qué consiste el modelo de justicia correctiva pensado por Aristóteles; la contrastaré con las concepciones, también aristotélicas, de justicia distributiva y de justicia retributiva, y observaré su posible correlato con la protección de los derechos humanos de personas víctimas y victimarias; ello por cuanto el modelo de justicia social restaurativa descripto parecería coincidir, en esencia, con el ideal de justicia correctiva aristotélico.

En el libro V, capitulo IV de Ética Nicomaquea, al describir la justicia correctiva de las transacciones voluntarias e involuntarias, Aristóteles indicó que tal justicia busca corregir la injusticia entre los cuatro términos de una ecuación -constituidos por las partes agresora y víctima, por una parte, y, por el daño infligido o acción causada y el daño sufrido o padecimiento, por la otravaliéndose de un criterio de equivalencia entre los sujetos y de diferencia en el daño: “...la ley mira sólo a la diferencia del daño y trata (a las dos partes) como iguales; y (atiende a) si uno comete injusticia y otro la padece, y si uno causó daño y otro lo ha sufrido."142

Según Aristóteles a diferencia de la justicia distributiva que siempre es proporcional a los méritos y contribuciones de cada uno, la justicia correctiva (a la que denomina la justicia de los "modos de trato") es una cierta igualdad, y lo injusto una desigualdad, pero una igualdad según una proporción aritmética y

\footnotetext{
141 Comunicado de Prensa de la Comisión Interamericana de Derechos Humanos Nro. 26/05.

142 Aristóteles, EN, V, 4, $1132 \mathrm{a}$.
} 
no proporcional a los méritos de cada cual. Dice Aristóteles:

"...lo mismo da que un hombre bueno haya defraudado a uno malo o que uno malo haya defraudado a uno bueno, o que el adulterio haya sido cometido por un hombre bueno o malo: la ley sólo mira a la especie del daño y trata como iguales al que comete la injusticia y al que la sufre, al que perjudica y al perjudicado. De modo que este tipo de injusticia, que es una desigualdad, la que el juez procura igualar; y así, cuando uno recibe un golpe y otro lo da, o uno mata y el otro muere, el sufrimiento y la acción se reparten desigualmente, pero el juez procura igualarlos con el castigo quitando del lado de la ganancia, pues en tales casos se usa en general el término "ganancia"... De suerte que lo igual es un término medio entre lo más y lo menos, y la ganancia y la pérdida son más y menos de manera contraria, porque la ganancia consiste en más bien y menos mal, y la pérdida en lo contrario."143

Luego de hablar de la justicia correctiva como una forma de igualar, propia de cualquier acción virtuosa según su teoría de la virtud como un justo medio, Aristóteles procede a criticar a quienes consideran que la reciprocidad sin más es justa, como afirmaban los pitagóricos que definían a la justicia como reciprocidad: "Si el hombre sufriera lo que hizo, habría verdadera justicia". ${ }^{144}$ Aporta numerosas razones para demostrar la falsedad de tal afirmación como criterio de justicia correctiva -aunque no así en los intercambios o en las asociaciones que tienen al intercambio como finalidad, en las que rige la reciprocidad entre lo que uno recibe y el otro aporta-.

A diferencia de la propuesta de Aristóteles, el modelo de punición retributiva examinado antes parece utilizar el principio de "reciprocidad proporcional", que Aristóteles aplicó exclusivamente para las relaciones comerciales en las que la moneda era el punto justo de intercambio de bienes y servicios en la polis: "...la ciudad se mantiene unida en razón de una reciprocidad proporcional: en efecto (los ciudadanos) procuran o (devolver) mal (por mal), y si no (pueden), creen que es esclavitud, o (devolver) bien (por bien) $y$, si no (pueden), no hay intercambio; $y$ es por el intercambio por lo que se mantienen unidos..." ${ }^{145}$ El método comparativo es propio de este tipo de justicia conmutativa, en la que se mide y busca equiparar los cuatro términos de la ecuación por medio de un cálculo, siendo la moneda el ecualizador.

\footnotetext{
143 Ibíd.

144 Obra citada, V, 5, 1133a.

145 Ibíd.
} 
Aristóteles también hablaba de favores y gratitudes (kharízien y khárites) en el comercio, una relación que caracteriza del siguiente modo: te doy, me das, te agradezco. Te doy, no me das, me debes, te maldigo.

El modelo de justicia retributiva -ya sea que se centre en pasiones vindicativas de las víctimas o sea consecuencia de políticas públicas de los estados tendientes a disminuir la tasa de los delitos en las sociedades- resulta inconciliable con una teoría de la justicia respetuosa de los derechos humanos de víctimas y victimarias. En consecuencia, el ideal de justicia correctiva, en el que ambas partes de un conflicto judicial son consideradas éticamente iguales y lo que se busca es restaurar el dolor padecido, dignificando el respeto y confianza menoscabados, y ampliar la consciencia de la persona perpetradora en relación con el acto causado mediante un ejercicio de autocorrección, es el que más se acerca al pleno respeto de los derechos humanos.

Lo desarrollado en esta primera parte de la investigación sobre la pertinencia de la consideración de las emociones morales en la justicia, y especialmente sobre las emociones vindicativas, me permite concluir que el inicio de la restauración de un vínculo comienza con el reconocimiento de la participación en los hechos violentos y con la manifestación de un sincero arrepentimiento, que expresado en el ámbito judicial y cualquiera sea la modalidad práctica que en justicia se adopte, revela un nuevo-conocimiento de la propia condición humana. El ser humano que logra arrepentirse con sinceridad recuerda su humanidad y los límites que le son propios, no se impone por encima de nadie, ni menoscaba su dignidad situándose por debajo de otros: se aflige por el daño que ocasionó y toma consciencia de su responsabilidad. Es por ello que al encontrarnos con un relato de arrepentimiento sincero en la justicia, podremos vislumbrar que quien así se exprese ya no se conducirá más de modo que vuelva a causar daño a sus congéneres; y esta expresión moral resultará de vital importancia al momento de efectuar una valoración en la sentencia que resuelva su condena o absolución.

En la sección segunda expondré la teoría neo-estoica de las emociones morales propuesta por Martha C. Nussbaum, que nos permitirá entender: 1) 
qué elementos cognitivos-evaluativos forman parte constitutiva, suficiente y necesaria de las emociones, 2) cómo podrían clasificarse y 3) qué valor aportan para la vida individual y social. Es posible que esclarecer estos tres puntos contribuya a que las emociones morales sean tenidas en cuenta por las personas encargadas de juzgar al momento de sentenciar sobre condenas o absoluciones, respetándose de tal modo todos los aspectos humanos envueltos en una situación conflictiva; lo cual favorecerá el pleno respeto de los derechos humanos. 



\section{Sección II: Marco Teórico de la Investigación}

\section{La Teoría Neo-Estoica de las Emociones de Martha C. Nussbaum}

A continuación estableceré el marco teórico de la investigación. Me concentraré en las obras de Martha Nussbaum La Terapia del Deseo: teoría y práctica en la ética helenística (1994) y Upheavals of Thought, The Intelligence of Emotions (2001). En la primera obra la autora abordó el estudio pormenorizado de las pasiones y las emociones que aportó la escuela helenística a través de sus tres corrientes filosóficas: el epicureismo, el escepticismo y el estoicismo, y en la segunda delineó su teoría neo-estoica sobre las emociones morales.

Elegí la teoría neo estoica de las emociones desarrollada por Nussbaum como marco general para la consideración de las emociones en la justicia en primer lugar porque, junto con Aristóteles, los filósofos helenistas fueron los primeros en reconocer el contenido cognitivo y evaluativo de las emociones morales. En segundo lugar, porque que es posible trazar un paralelismo entre el mundo en crisis de la cosmópolis helenista y nuestro mundo globalizado, especialmente en lo que atañe a la pérdida de seguridad en cuanto a la posibilidad de pertenecer a una polis común y de desarrollar las virtudes cívicas dentro de un espacio político común. En efecto, en nuestro mundo globalizado actual también experimentamos una especial retirada desde lo político hacia lo individual, porque hoy la otra cara de la globalización es el individualismo ético. Y, en tercer lugar, porque la teoría de Nussbaum conjuga de manera original y valiosa la tradición helenista con la aristotélica porque, a diferencia del grueso de estoicos y epicúreos, Aristóteles“...invita al cultivo de muchas emociones 
como partes valiosas y necesarias de la acción virtuosa..."146

Desde hace varios años, la filósofa helenista Martha Nussbaum está trabajando en una tesis bastante original: “...las emociones son respuestas inteligentes a la percepción de los valores..."147 Lo cual implica que las emociones no se encuentran disociadas de la razón como si ambas, emoción y razón, fueran compartimentos estancos del ser humano, sino que interactúan revelando aquello que para cada persona resulta valioso y dando cuenta de su sentido ético de dignidad humana. Si las emociones están relacionadas con la inteligencia, y si contienen una advertencia sobre el valor o importancia de ciertos objetos externos, entonces, concluye Nussbaum, no pueden ser dejadas de lado en los juicios éticos. ${ }^{148}$ Además, y como consecuencia de su estructura cognitiva, sostiene la autora que las emociones poseen una dimensión narrativa porque hacen referencia a una parte de nuestra historia y de nuestras relaciones con los objetos involucrados.

Nussbaum se apartó de la tesis radical de los estoicos, quienes consideraban que las creencias propias de las emociones que causan sufrimiento humano tenían que ser extirpadas para lograr la eudaimonía y esbozó lo que ella misma denomina una teoría "neo-estoica" sobre las emociones. Para ello, tomó en cuenta el rol que juega la imaginación en algunas emociones y formuló una distinción categórica entre "emociones generales" y "emociones particulares" y entre "emociones contextuales" y "emociones históricas".

Lo importante de su planteo, para esta investigación, es la relación que estableció entre las emociones y los juicios éticos sobre "cosas importantes" para nuestro bienestar, por un lado, y, por el otro, cómo contextualizó el conflicto emocional en relación con el mundo al que, según ella, no podemos controlar plenamente: “...las emociones son, entonces, una forma de reconocer nuestra necesidad y falta de autosuficiencia...". 149 Este es un punto importante, en el que su teoría sobre la racionalidad de las emociones se diferencia de la

\footnotetext{
146 Nussbaum, M., La Terapia del deseo..., obra citada, p. 111 y siguientes.

147 Martha Nussbaum, Upheavals of Thought..., obra citada, p. I.

148 Ibíd.

149 Obra citada, p. 22.
} 
teoría de Solomon, para quien tener una emoción implicaba siempre un estado de autocontrol.

Para construir esta hipótesis Nussbaum se distanció del análisis que los estoicos efectuaron sobre las emociones. Bajo su esquema teórico las emociones ya no son "fuerzas impensadas" o energías que arrastran a las personas de un limbo hacia otro, sino que están conectadas con el modo en que ellas perciben y razonan acerca del mundo. Recordemos que dicha evaluación estoica sobre las emociones deriva de vincularlas con una parte "animal" de la naturaleza humana, más que con una específica parte humana, y se relaciona con la idea que las emociones son corporales antes que mentales. Contra esta posición estoica, Nussbaum sostiene que: “...aunque creo que las emociones son corporales, como otros procesos mentales, también creo y debo argüir que, siendo que toman un lugar en el cuerpo, ello no es suficiente para reducir su componente intencional-cognitivo a meros movimientos corporales no intencionados...". 150 Siguiendo ésta línea de pensamiento, Nussbaum afirma que nuestros cuerpos están imbuidos de inteligencia e intencionalidad y que la visión estoica del "adversario" resulta, por lo tanto, "groseramente inadecuada". ${ }^{151}$ Al brindar una respuesta a la posición estoica del adversario, explica la autora que:

“...las emociones son una especie de juicio o pensamiento en el que, al parecer, se dificulta dar cuenta de su urgencia e intensidad; ya que los pensamientos fueron típicamente imaginados como desafectados o calmos. Pero también es difícil encontrar en ellos pasividad... porque los juicios parecen ser cosas que activamente hacemos, no que sufrimos. Y la clásica posición estoica del adversario omite también la capacidad para dejar de lado el ego: como si los pensamientos fueran paradigmas de aquello que podemos controlar, y de las partes de nuestra identidad que con más seguridad manejamos..." ${ }^{152}$

Según Martha Nussbaum, la posición estoica no solamente reduce el estado emocional a una respuesta corporal, sino que ubica al ser humano en situación de pasividad ante su propio estado emocional. En tal perspectiva, la persona se encuentra "atraída" por objetos o sujetos externos a los que le atribuye su emoción; pero esta posición no alcanza a explicar algo que

\footnotetext{
${ }^{150}$ Ibíd., p. 25.

${ }^{151}$ Explica que la visión reduccionista del adversario encuentra apoyo en las corrientes de la filosofía empírica humeana y de la psicología conductivista típica del derecho criminal.

152 Ibíd., p. 27.
} 
considero innegable: que las emociones operan en el interior de cada ser humano en íntima relación con sus pensamientos, y como consecuencia del valor que le atribuye a aquellos objetos o sujetos externos a los que no puede controlar, o que cree ilusamente que puede controlar.

Nussbaum refuta la tesis estoica que postula que las emociones son energías enardecidas o fuerzas que nos arrastran de un limbo a otro argumentando que las mismas contienen, básicamente, tres elementos cognitivos:

- Primero: el objeto emocional, las emociones son "sobre algo", tienen un objeto formal de conocimiento. Por ejemplo, el objeto formal de la ira es la ofensa, el del temor es la amenaza o peligro, el de la compasión el sufrimiento ajeno y el de la envidia el bienestar ajeno;

- Segundo: el objeto es intencional, es decir que las emociones se dirigen "hacia algo". La intencionalidad se traduce como la emoción definida desde el punto de vista interior de la percepción que la persona tiene sobre sí misma y sobre su propia vida. Según Nussbaum, lo que distingue al temor de la esperanza, al odio del amor o al placer del dolor no es la identificación con el objeto formal sino la propia perspectiva sobre dicho objeto. Por ejemplo, el dolor que causa la muerte de un ser querido, "percibida" como una pérdida, la pena que causa el sufrimiento ajeno, "percibida" como algo que podría estar sucediéndome a mi y la envidia que causa el bienestar ajeno, "percibida" como el fracaso de mis propias metas y objetivos de vida.

- Tercero: las emociones llevan insita una "creencia" sobre el objeto, ello es descripto por la autora distinguiendo entre ver a $X$ como $Y$ o tener la creencia de que $X$ es $Y$. Por ejemplo, el enojo está basado en una complejidad de creencias: acerca del daño que una misma o un ser querido padece; sobre el significado que ese daño significa para una o para esa persona importante y en la creencia que fue causado con intencionalidad de dañar.

El primer elemento supone un conocimiento acerca de lo que es el objeto de la emoción, y los dos últimos -percepción intencionada y creenciaestán imbuidos de valor, puesto que permiten ver dicho objeto como algo valioso o importante.

A diferencia de los filósofos que definieron las emociones morales en términos de meras creencias, Martha Nussbaum considera que las creencias son sólo una parte constitutiva de las mismas que cumplen el requisito de necesidad pero no de suficiencia, puesto que otros elementos cognitivos 
también las integran. Esta es una distinción sutil pero sustancial, con la que comienza a delinear su teoría, contrastándola con la teoría estoica de Séneca.

Hay algunos puntos de su teoría que resaltaré: en primer lugar que las emociones permiten ver el mundo desde el punto de vista del propio esquema de metas y proyectos de cada ser humano, de aquellas cosas a las que agrega valor según una concepción de lo que estima importante para sí, para vivir bien. En este sentido, entonces, tienen un componente subjetivo irreductible que da cuenta del sistema de creencias y valores de una persona.

Para Nussbaum las evaluaciones asociadas a las emociones son evaluaciones bajo la propia perspectiva del individuo, y contienen una referencia in-eliminable al yo. Aclara que este sentido íntimo de subjetividad, que revelan las emociones, hace que las mismas sean empáticas y no egoístas, puesto que el ser humano que experimenta una emoción otorga con ella valor intrínseco a las personas, objetos o ideas en función de la importancia que tienen en su esquema de metas y proyectos de vida. ${ }^{153}$

Por otro lado, Nussbaum piensa que la forma de evaluar la intensidad de una emoción está relacionada con la intencionalidad, con que se reviste al objeto emocional, esto es así por la importancia subjetiva que ese objeto tiene en el propio esquema de objetivos y proyectos de cada ser humano. En el enojo, por ejemplo, la intensidad suele ser proporcional al tamaño del daño que se considera que ha ocurrido y el dolor sentido suele ser proporcional a la medida de la pérdida que este representa. ${ }^{154}$ Nussbaum opina, y coincido con ella en este punto, que muchas veces las emociones suelen ser desproporcionadas respecto de sus objetos, por cuanto solemos tener una opinión sesgada de lo que es el objeto de dolor o pérdida, viéndolo más o menos importante de lo que realmente es. Por esta misma razón Nussbaum piensa que en la vida pública las emociones nunca deben ser consideradas como "buenas en sí mismas" y deben estar puestas en constante dialogo con los principios éticos.

Pero las emociones poseen además una rica y densa percepción del

${ }^{153}$ Ibíd., pp. 49-56.
154 Ibíd., p. 56. 
objeto emocional, compuesta por una carga imaginativa que también forma parte de las mismas. La imaginación o "cuadro de situación" es lo que diferencia a las emociones de otros estados evaluativos. Nussbaum se cuestiona por qué enfocamos la imaginación en algunos objetos y no en otros y cómo esa selección resulta relevante para conocer el contenido racional de las emociones y encuentra respuesta en la otredad, puesto que la imaginación es un "puente" que permite reflejar interiormente a otro ser humano y convertirlo en objeto de nuestra compasión. ${ }^{155}$

Por último la autora formula una interesante distinción de los juicios de valor, asociados al dolor emocional, clasificándolos en dos grupos: históricos o situacionales y generales o concretos. Las emociones históricas son aquellas que surgieron en el pasado y que persisten en el tiempo a través de situaciones de diverso tipo, repitiéndose. Las emociones situacionales son aquellas que surgen del contexto actual y se manifiestan en el momento presente. Las emociones históricas, permiten explicar patrones de comportamiento. Aclara Nussbaum que las emociones históricas no necesariamente son inconscientes -como tampoco no necesariamente las contextuales son conscientes-, pero que frecuentemente lo son, puesto que resultan ser condiciones humanas persistentes que, a menudo, pasan inadvertidas para la persona que las tiene. Una emoción general, propone Nussbaum, frecuentemente descansará sobre un contexto histórico y a la vez será situacional. Una emoción concreta será situacional, pero estará al acecho del pasado. Las emociones históricas reconocen dependencia o necesidad por algún elemento del mundo que nos resulta ingobernable. Las emociones situacionales responden al modo en que el mundo cumple o incumple con las necesidades del ser humano. ${ }^{156}$

Para concluir con la exposición del marco teórico de esta investigación, volveré sobre el análisis de dos emociones morales vindicativas: la ira y la repugnancia, porque fueron recurrentemente expresadas por las partes, testigos y autoridades judiciales en la sentencia condenatoria elegida para aplicarlo.

\footnotetext{
155 Ibíd., pp. 64-67.

156 Ibíd., pp. 72-74.
} 
Los filósofos helenistas tuvieron una posición relativamente unánime sobre la conveniencia de erradicar las pasiones de la vida pública y privada. Esta era la posición de Epicuro, por ejemplo, en su Carta a Herodoto sobre la cólera, quien le propuso el autocontrol y la autosuficiencia como mecanismos para evitar el estado de debilidad o necesidad que tanto la cólera como la gratitud generan. Filodemo, por su parte, sugería que era suficiente otorgar menor importancia a las cosas externas, incluyendo lazos sociales y familiares, para evitar el enojo y la agresión.

Nussbaum critica esta posición epicúrea sobre la erradicación de la ira, porque considera que dicha actitud supondría una cierta frialdad en los vínculos que puede llegar a ocasionar un sentimiento de soledad. Esta actitud, sugiere la autora, tiene que ver con una concepción del ser humano semejante a los seres divinos. Toma el ejemplo de Lucrecio, para quien los rasgos de autosuficiencia y completitud eran propios de los seres divinos, diosas y dioses, que estaban libres de turbación y, por eso mismo eran invulnerables ante la violencia. Como dice Nussbaum:

“...los dioses son modelos, pero en sentido negativo. Carecen de nuestra cólera y nuestra debilidad, pero también parece faltarles, por ello, mucha de las artes que nosotros hemos inventado para hacer frente a nuestra debilidad: entre ellas, la moralidad social y la filosofía... reflejan la autosuficiencia de las bestias y, como ellas carecen de la base cognitiva de la cólera... porque les falta cierto tipo de implicación en el mundo $y$ en sus avatares que puede ser inevitable, e incluso buena, en una vida humana..." ${ }^{157}$

Nótese que Nussbaum dice que los dioses carecen de de la "base cognitiva" que proporciona la cólera. Llegamos aquí a un tema de gran importancia para esta investigación: la cólera tiene una "base cognitiva" que nos permite hacer frente a las debilidades, y podríamos decir también que puede cooperar a diseñar instituciones, como la moral social, para no lidiar con tales debilidades ni huir de ellas. A diferencia de las fieras, para quienes el sol o la lluvia son agresiones naturales; el sentimiento de hostilidad en el ser humano es algo más preciso y complejo que una situación de amenaza ante la vida; es percibir que el daño ha sido causado voluntariamente. $\mathrm{Y}$ al agregar "voluntariamente" Nussbaum estaría significando que la cólera en el ser

${ }^{157}$ Citado por Nussbaum en La Terapia del Deseo..., obra citada, p. 323. 
humano tiene que ver con situaciones que "podrían haber sido de otra manera" porque no son necesarias ni azarosas, como decía Aristóteles, sino que estuvo en la voluntad del sujeto no haberlas realizado, y es por esas acciones que se nos elogia o se nos censura. ${ }^{158}$

Vemos aquí la profundidad con que la autora investiga el contenido cognitivo y valorativo que las emociones tienen en los seres humanos. Este punto será nuevamente abordado al revisar su teoría neo estoica de las emociones a la luz de la sentencia judicial escogida, puesto que estimo que constituye un pilar fundamental en la incidencia del reconocimiento emocional en la justicia para el efectivo ejercicio de derechos humanos.

Preocupados por lograr que el ser humano se encuentre libre de pasiones (apathēs), los exponentes de la escuela estoica propusieron arrancar de raíz las creencias que constituían el origen de las mismas. Sin embargo, como señala Nussbaum, la obtención de esa libertad bajo la perspectiva estoica también implicaba concebir al ser humano como invulnerable y completamente autosuficiente: "...La aflicción nunca le afecta: su alma está serena y nada puede ocurrirle que la ensombrezca...." 159 Insistían una y otra vez sobre la falsedad de los juicios en los que se basan las pasiones. Sobre el particular, Martha Nussbaum expresa que esos mismos juicios de valor que para los estoicos resultaban falsos, para la posición aristotélica eran verdaderos, puesto que motivaban a llevar a cabo una acción correcta: "...los motivos de la pasión son en muchos casos más valiosos moralmente que los motivos del deber, en la medida en que ponen de manifiesto inquietudes $y$ compromisos que son en sí mismos éticamente valiosos..." ${ }^{160}$

Nussbaum, nuevamente, encuentra en Aristóteles respuestas al reconocimiento del valor que las emociones tienen para el ser humano, apartándose de las ficciones propuestas por epicúreos, escépticos y estoicos consistentes, respectivamente, en: modificar las creencias "vanas" o "falsas" en que las mismas se basan; no comprometerse con el conflicto emocional,

\footnotetext{
158 Aristóteles, Ética Nicomaquea, obra citada, Libro III, I. Esta distinción aristotélica resulta relevante, por ejemplo, para arrojar luz sobre el tan debatido tema de la "obediencia debida" y la imputabilidad moral y jurídica de las acciones.

${ }_{159}$ Nussbaum, M., La Terapia..., obra citada, p. 483.

160 Obra citada, p. 485.
} 
adoptando una distancia que enfríe la situación; y erradicarlas por completo de la vida humana, por medio de la serenidad en el alma. Sin embargo, actitudes de exagerada autosuficiencia u omnipotencia -tanto en la vida individual, como en la vida social y política-, la ruptura de lazos sociales conflictivos y una actitud de distanciamiento frente a un mundo que se considera hostil e imposible de cambiar, pueden generar también situaciones de violencia, densas de contenido emocional, tanto respecto de quien adopta tales actitudes, porque se niega a aceptar su propia vulnerabilidad y límites, como respecto de las demás personas por encima de quienes se sitúa aquella con dicha actitud, puesto que podría resultar en una jerarquía de vínculos que, como bien recuerda Nussbaum, conspira en contra de la igualdad ética.

Hasta aquí he reseñado la teoría neo-estoica de las emociones morales de Nussbaum, que constituye el marco teórico de esta investigación. En lo que sigue, intentaré mostrar que el tema también es relevante para contribuir a una real comprensión del alcance de los derechos humanos y sus posibles lesiones. 


\section{Emociones y Derechos Humanos}

Los derechos humanos surgieron en un mundo escandalizado por los horrores de las guerras, de los odios raciales y de la voluntad imperial de algunos. A partir de ese momento existe un consenso, más o menos extendido, acerca de la necesidad de cultivar los valores republicanos de igualdad ética, libertad individual y fraternidad; así como de reconocer y aceptar la diversidad material -económica, social, religiosa, étnica, cultural, de género y de toda otra índole- plasmada en todas las normas de protección de los derechos humanos y de fomentar, socialmente, la solidaridad.

Estimo que una actitud escéptica de distanciamiento o no compromiso ante el curso de acontecimientos penosos para la humanidad obstaculiza el cimiento de lazos solidarios entre pueblos e individuos; aunque sería ingenuo sostener que el mero cultivo individual y social de vínculos solidarios sea suficiente de por sí para lograr el efectivo respeto de los derechos humanos, ya que los mismos se conquistaron con sangrientas luchas en contra de quienes los violaron masiva y sistemáticamente. Actualmente ocurren en distintos puntos del planeta injusticias estructurales como la extrema pobreza, desnutrición, desplazamiento sistemático de pueblos de un territorio hacia otro, condiciones insalubres de vida e innumerables acontecimientos que constituyen serias y graves violaciones a los derechos humanos civiles, políticos, sociales, económicos y culturales; circunstancias que obviamente perturban el equilibrio emocional no sólo de quienes las padecen sino que también de otros seres humanos y grupos sociales en quienes causan consternación y un profundo sentimiento de malestar.

Lo cierto es que el desencanto heleno por la "política" imperial dotó al mundo de un pesimismo sobre la posibilidad de cambiarlo y, al mismo tiempo, de bellísimos y valiosos textos sobre "psicología moral" individual. La teoría neo-estoica de las emociones morales de Martha Nussbaum y este trabajo de tesis, humildemente en este último caso, intentan rescatar la valiosa psicología moral estoica sin caer en el pesimismo del helenismo imperial. A diferencia de los estoicos para quienes el conflicto emocional era una batalla de fuerzas impensadas, de energías contrapuestas o de vientos arremolinados que 
constituían la herida y luchaban hasta que uno de ellos ganaba, la perspectiva neo-estoica de Nussbaum ofrece un abordaje autocrítico y a la vez contextual en el análisis del conflicto emocional; ya sea del conflicto de emociones entre sí o de emociones con otros juicios éticos. El conflicto entre emociones polarizadas: como temor y esperanza, enojo y gratitud o tristeza y alegría era, a criterio de Nussbaum, "pésimamente" interpretado por los estoicos como fuerzas encontradas; Nussbaum considera que las emociones, al compartir características, establecen una relación dinámica entre sí que permite agruparlas en dos clases: emociones genéricas o concretas y emociones históricas o situacionales. En consecuencia, bajo la teoría neo-estoica de Nussbaum, podemos entender a las emociones morales como cierta clase de "visión" o reconocimiento, como un modo valorativo de autoconocimiento en correlato con la comprensión del mundo, que justifica su consideración en la justicia en función con el respeto de los principios éticos de los derechos humanos.

En la parte segunda de la investigación, aplicaré el marco teórico elegido. En primer lugar, estudiaré el contenido cognitivo-evaluativo que tiene la repugnancia, analizaré qué rol desempeña en la esfera pública y examinaré su posible reivindicación ante crímenes de lesa humanidad; todo ello teniendo en consideración que, junto con la ira y el deseo de venganza o revancha emociones morales a las que ya me he referido en la parte primera-, es una de las emociones que más ha sido invocada en el acto judicial decisorio escogido para aplicar el marco teórico.

Luego de realizar una lectura del texto de la sentencia que condenó a Miguel Ángel Etchecolatz -ex agente de seguridad del estado- por crímenes de lesa humanidad perpetrados durante la última dictadura militar en Argentina, intentaré descubrir en el texto mismo qué peso que tuvieron en su redacción las expresiones emocionales vertidas por los distintos actores $\mathrm{y}$, también, si dichas emociones fueron compatibles con el objetivo de restaurar la dignidad humana de las víctimas y hacer posible que el perpetrador del delito tomara conciencia de la gravedad de los actos causados y de las secuelas que los mismos produjeron en las víctimas y en la sociedad. Finalmente, aplicaré el marco teórico a las expresiones emotivas manifestadas por las autoridades 
judiciales en el fallo en cuestión y evaluaré su pertinencia en función del respeto de los principios de autonomía personal e imparcialidad en la justicia. 


\section{PARTE SEGUNDA}

Aplicación del Marco Teórico 



\section{Sección I: Estudio sobre la Repugnancia}

\section{Introducción y nociones}

Por lo general, el contenido intencional de la repugnancia suele estar asociado con la idea de adulteración de la sustancia del objeto que produce repulsión desde la perspectiva de quien se repugna e independientemente de que esa contaminación sea real o simbólica. Se la suele asociar también con el asco, y en los últimos años hubo una interesante discusión sobre el papel de lo que se denomina el "asco moralizado" en la esfera pública y también en la justicia penal. $^{161}$

Martha Nussbaum se ocupó de la repugnancia, especialmente de su génesis, como una emoción que se manifiesta en la primera niñez a partir del reconocimiento de los límites del propio cuerpo y del contacto con las excreciones humanas. ${ }^{162}$ Para ella, la boca constituye "un borde especialmente recargado" por todo lo que ingresa y egresa de nuestras bocas y por el contacto previo que esos "objetos" tuvieron con otros tantos objetos, lo cual se asocia con ideas de intoxicación e indigestión revulsivas. Sostiene la autora que la repugnancia encuentra su raíz en la primitiva vergüenza o pudor, que surge cuando descubrimos que somos animales humanos necesitados, tratándose de una emoción aprendida mediante enseñanzas parentales y sociales. ${ }^{163}$ Según Nussbaum, “...mediante la enseñanza de la repugnancia y sus objetos, las sociedades transmiten actitudes respecto de la animalidad,

\footnotetext{
${ }^{161}$ Sobre el asco moralizado véase Salles, Arleen, (2010), "Sobre el asco en la moralidad”, México, Dianoia, Vol LV, Nro. 64, pp. 27-45.

162 Nussbaum, M., Upheavals of Thought, Cambridge: Cambridge University Press, 2001, 8va. impresión, 2008. Véase el capítulo 4, "Emotions in Infancy", punto IV, "Disgust and the Borders of the Body", pp. 200-206. ${ }^{163} \mathrm{La}$ autora analiza la sexualidad y la repugnancia social representacional que genera la idea de penetración en las relaciones entre homosexuales. Aclara, en la nota al pie, que en las relaciones heterosexuales los hombres suelen ver a su pareja como animales "que reciben la polución de sus fluidos", todo lo cual lo explica ella como una intolerancia a la propia humanidad. Véase en la obra citada, pp. 349-350.
} 
mortalidad, y cuestiones relacionadas con el género y la sexualidad..." ${ }^{164} \mathrm{Y}$, añade que reacciones repugnantes proyectivas como la misoginia, el antisemitismo y la aversión hacia homosexuales son poderosos patrones sociales en los que yace una idea de contaminación, que conduce a formas de jerarquización social destructivas. ${ }^{165}$

En los comienzos de la década del ochenta, Paul Rozin y April Fallon efectuaron una serie de estudios sobre la repugnancia, retomando las formulaciones del comportamiento hechas precedentemente por los antropólogos Charles Darwin en The Expression of the Emotions in Man and Animals (1872) y Andras Angyal en Foundations for a Science of Personality (1941). ${ }^{166}$ Rozin y Fallon afirmaban, en una línea similar a la de Nussbaum, que se trata de:

“...una emoción relacionada con la alimentación, definida como la revulsión a la posible incorporación oral de objetos ofensivos... Como otras emociones básicas, la repugnancia tiene una expresión facial característica... una acción apropiada (el distanciamiento con el objeto ofensivo), una manifestación psicológica distintiva (náusea), y un característico estado sensitivo (revulsión)..."167

Explicaban Rozin y Fallon que los objetos resultan ofensivos porque son percibidos como "contaminantes", ${ }^{168}$ puesto que la repugnancia se asienta en una creencia popular, cultural y religiosa, consistente en pensar que "somos lo

\footnotetext{
${ }^{164}$ Nussbaum, M., Upheavals..., obra citada, p. 205.

165 Ibíd., p. 297.

166 Se puede consultar A Theoretical Model for Personality Studies, la teoría determinista de Angyal, reformulada en 1951 en: http://www.panarchy.org/angyal/personality.html. Aquí el autor refiere que el ser humano que establece relaciones transversales, en tanto se considera parte de un todo, reconoce la otredad principalmente por medio de sus sentimientos de amor, lo que le permite autoafirmarse y aceptarse como un fin en sí mismo. Añade que actitudes destructivas de explotación, dominación, posesión e indiferencia socavan la autonomía individual de los seres humanos, reduciéndolos a medios para un fin. Angyal construye una teoría holística sobre la base de dos traumas básicos auto-derogatorios que afectan la neurosis de los seres humanos: el sentimiento de pérdida, relacionado con la incapacidad autoafirmación y el de ansiedad, relacionado con la incapacidad de renunciar y el temor a amar, que generan comportamientos fóbicos de aprensión, envidia, sospecha y odio, así como sentimientos de abandono e inseguridad. Ambos traumas se originan con las relaciones parentales de la infancia y se arrastran hasta la adultez, como una falta de madurez acerca de la concepción del mundo en que vivimos, que sigue siendo percibido -limitada o infantilmente- como "mi" mundo, recreando experiencias traumáticas de separatividad e incompletitud basadas en creencias de debilidad y no merecimiento de amor.

167 Paul Rozin y April E. Fallon, “A Perspective on Disgust”, en Psychological Review, 1987, vol. 94, Nro. 1, pp. 23-41.

168 Para Rozin y Fallon, la repugnancia puede generarse por contaminación negativa, como una reacción ante la amenaza de daño, o por contaminación positiva o "transvaloración", cuando se incorporan objetos con la finalidad de alterar positivamente la sustancia en el organismo.
} 
que comemos" ${ }^{\text {169 }}$ adquiriendo preponderancia psicológica, en torno a la "incorporación" del objeto a nuestro organismo, lo que el antropólogo social escosés Sir James George Frazer denominó, en su obra La Rama Dorada (1890), como "magia simpatética". 170

En otras palabras, lo que los investigadores fueron descubriendo es que la repugnancia efectivamente recaía sobre ciertas valoraciones acerca de los límites de la acción y libertad sobre el propio cuerpo y el ajeno, y acerca de las impresiones que causa el conocimiento de las acciones que terceras personas llevan a cabo libremente con sus propios cuerpos; y este juicio de valor, obviamente, puede desencadenar prejuicios raciales, homófobos, etc. Pero también, comprobaron que a la gente le repugnan el racismo, la discriminación, los crímenes ultrajantes y de guerra, la hipocresía, la corrupción política y transgresiones sociales tales como abandonar a los padres mayores y maltratar a hijos e hijas por revelarse contra patrones de dominio patriarcal.

Vemos que lo que causa repugnancia es antes una transgresión "moral" en el trato humano que "legal", pero que ambas pueden confluir. Existe en dicha transgresión una fuerte sensación de afrenta a la dignidad humana.

En un trabajo reciente, "From Oral to Moral" (2009), ${ }^{171}$ Rozin analizó la repugnancia como un sistema normativo de apreciación evaluativa compuesto por el contenido cognitivo contaminante, las valoraciones sobre ese contenido y las sensaciones de revulsión que genera. De este modo Rozin respondió a las

169 Véase también: Paul Rozin, Linda Millman y Carol Nemeroff, "Operation of the Laws of Sympathetic Magic in Disgust and Other Domains”, en Journal of Personality and Social Psychology, 1986, Vol. 50 Nro. 4, pp. 703-712.

${ }^{170}$ Frazer, J. G., (1890), The Golden Bough: A Study in Magic and Religion, publicado por Forgotten Books en 2008 en: http://books.google.es/books?id=4bT3ACjkRasC\&lpg=PP1\&pg=PP1\#v=onepage\&q\&f=false. En esta obra, Frazer expuso cómo las experiencias míticas fueron transferidas al sacerdocio, o sea a lo religioso, y cómo dichas experiencias mágicas o religiosas -que buscan satisfacer en el ser humano su deseo de trascender su condición de animal- aún continuaban en ese entonces aplicándose en diferentes culturas, por medio de dos leyes simpáticas que la explican: la ley de semejanza u homeopatía y la ley de contacto o contaminante. Mediante la ley de semejanza causas semejantes producen efectos semejantes y la "magia" se produce por un mecanismo de imitación. Según la ley de contagio, objetos que alguna vez estuvieron en contacto físico con una persona siguen actuando, a pesar de la distancia (física), afectando "mágicamente" a la persona. Según Frazer ambas leyes, cuando operan juntas, se denominan "magia simpatética" puesto que establecen una relación sutil, secreta, de simpatía entre sí, que explica la interacción reciproca o poder etérico de mutua influencia a pesar del vacío o la distancia. Véase: Sir James George Frazer., The Golden Bough: A Study in Magic and Religion, re-publicado por Forgotten Books en 2008. http://books.google.es/books?id=4bT3ACjkRasC\&lpg=PP1\&pg $=$ PP1\#v $=$ onepage\&q\&f=false

171 Paul Rozin, Jonathan Haidt y Katrina Fincher, "From Oral to Moral", en Science 27 February 2009: Vol. 323. no. 5918, pp. 1179 - 1180. 
objeciones frecuentes que se formulan en torno al contenido evaluativo de la repugnancia, que suelen argüir que la relación entre moralidad y repugnancia es metafórica. Para Rozin, en cambio, es indudable que algunas injusticias y otras violaciones morales suelen ser el punto de partida de la repugnancia o asco moral.

Por su parte, en su obra El ocultamiento de lo Humano (2006), Nussbaum exploró el contenido cognitivo de la repugnancia en la psicología individual, concluyendo que es eminentemente visceral y se relaciona principalmente con los sentidos "táctiles" -tacto, olfato y gusto-. Para la autora la idea de lo contaminante se revela como un límite o violación de fronteras aceptadas y la repugnancia aprendida en la edad adulta constituye una fuerza social que convierte la atracción en aversión. Dicha atracción por los objetos que resultan repugnantes se explica en términos psicológicos como consecuencia de la represión, parental y social, ejercida en la primera infancia en relación con las heces, proceso que se convierte en aversión cuando a niñas y niños se les enseña e inculca normas de higiene y salud en relación con sus productos corporales. ${ }^{172}$

Este fenómeno percibido por el ser humano como vulnerabilidad a la degradación natural, sin duda tiene implicancias también en la construcción política de la dignidad humana y en su protección jurídica normativa. Ello es así por cuanto una sociedad democrática, pluralista e inclusiva debería intentar proteger al ser humano como sujeto de derecho de prácticas culturales aberrantes que "repugnantemente" lo degraden física, sexual, psíquica, emocional o espiritualmente. Obviamente que el criterio de indignación podría invocarse, por ejemplo, frente a prácticas culturales de mutilación no consentida de partes del cuerpo humano de otros seres, o ante el trato inhumano y degradante que se le otorga a la mayoría de las personas privadas de su libertad en los centros de detención "legales" pero, tanto desde el punto de vista de quien padece la situación como de aquellas personas que la perciben y no tienen poder para combatirla, también podría válidamente alegarse repugnancia o asco moral.

172 Martha C. Nussbaum, El Ocultamiento de lo Humano..., obra citada, pp. 106-120. 
Por esta razón, entonces, y con todas las salvedades del caso, tal como dice William Ian Miller en The Anatomy of Disgust (1997) y como ya lo había advertido Darwin, podríamos admitir que: "sentir repugnancia es humano y humanizante". 173

\section{Repugnancia en la esfera pública}

En la sentencia condenatoria de Etchecolatz, los jueces afirmaron de manera rotunda que:

"No habiendo atenuante de ninguna especie para las conductas Ilevadas a cabo por Etchecolatz, se impone aplicar el máximo de la pena prevista por nuestra legislación dado que cualquier otra opción resultaría repugnante a nuestras convicciones".

El hecho de aludir a una emoción tan controvertida desde el punto de vista moral y jurídico se relaciona, indudablemente, con la atrocidad de los crímenes cometidos. Ahora bien, ¿de qué modo podríamos justificar la apelación a una emoción reactiva de tal naturaleza en el ámbito de la justicia penal? Y, ¿qué argumentos esgrimen quienes la condenan de plano?

Como hemos visto antes, el contenido intencional de la repugnancia suele estar asociado con la idea de adulteración de la sustancia del objeto formal de conocimiento que produce repulsión desde la perspectiva de quien se repugna e independientemente de que esa contaminación sea real o simbólica.

Quizás sería correcto, sin embargo, hablar de un doble efecto que presenta la emoción moral de repugnancia o, como lo denomina Miller, de su carácter "paradojal". Puesto que si bien puede ser una emoción útil en el sentido de arrojar luz sobre la comisión de hechos atroces, porque es capaz de operar como un censor de lo que es incorrecto, también puede convertirse en un vicio intrínsecamente pernicioso por cuanto torna parcial el juicio de aquello que repugna al individuo que efectúa la evaluación moral siendo, en consecuencia, una de las emociones que genera mayor discriminación.

Dicho efecto pernicioso de la repugnancia, en el marco de sociedades democráticas, pluralistas e inclusivas, consiste incluso en atentar, contra los

173 William Ian Miller, The Anatomy of Disgust, Cambridge: Harvard University Press, 1997, p. 11. 
derechos de las minorías, grupos o pueblos que integran dichas sociedades a la libre expresión de su diversidad cultural; acto que constituye una violación de derechos humanos. Es en este sentido que Martha Nussbaum ha señalado, siguiendo con la metáfora de la repugnancia como rechazo por el cuerpo animal humano propio, que luego se proyecta irracionalmente hacia otros individuos o grupos vulnerables, que:

"Dado que la repugnancia corporiza un rechazo a la contaminación que está asociado con el deseo humano de ser "no animal", está frecuentemente vinculada con ciertas prácticas sociales dudosas, en las que la incomodidad que las personas tienen por el hecho de tener un cuerpo animal se proyecta hacia fuera a individuos y grupos vulnerables. Estas reacciones son irracionales, en el sentido normativo, tanto porque corporizan la aspiración de convertirse en un tipo de ser que uno no es, como porque, en el proceso de perseguir esa aspiración, hacen de terceros el blanco de perjuicios graves". ${ }^{174}$

De tal modo, para Nussbaum el sentimiento de repugnancia en la esfera pública puede incluso ser consecuencia del reflejo expresado en otro ser humano o grupo respecto de aquello que aún no hemos resuelto interiormente y que nos causa una incómoda perturbación. Simbólicamente, podría afirmar que en esto consiste la idea de contaminación, en desaprobar, rechazar y negar un aspecto humano que hace al respeto por la libertad de opciones diferentes.

De acuerdo con esta interpretación, la repugnancia busca purgar -en un sentido epicúreo- aquello que resulta una amenaza o riesgo contaminante para quien la experimenta, y entonces su objetivo intrínseco es eliminar el objeto formal de su repugnancia, ya sea que se trate de ideas, sujetos u objetos valorados como "impuros" que la causan. En tal sentido, la repugnancia expresada en términos públicos, políticos y sociales, constituye un serio peligro para el respeto de los derechos humanos. Ello es así por cuanto quien siente repugnancia por las diferencias culturales, sociales, religiosas, de género o de otra índole, expresa su discriminación, desconsideración y ausencia de respeto por la libertad individual y diversidad cultural de sus congéneres.

Es por ello que analizando el esquema propuesto por Adam Smith en su Teoría de los Sentimientos Morales (1759), Miller atribuyó a un "espectador o

\footnotetext{
${ }^{174}$ Nussbaum, M., El Ocultamiento de lo Humano..., obra citada, p. 93.
} 
juez imparcial" la repugnancia como pasión apropiada ante la observancia de hechos aberrantes, que se genera por un sentimiento de simpatía o empatía respecto de la persona que se encuentra despreciada, sometida o vulnerada. Pero dicha pasión de quien observa, según Smith, tenía que ser modulada -ni excesiva, ni insuficiente, sino justa- para poder ver al otro como si esa persona se viera a sí misma en tal situación. La cuestión sería, entonces, saber si quien observa imparcialmente, que supuestamente tiene distancia emocional suficiente para juzgar los actos causados, seguiría sintiendo repugnancia por los mismos al ponerse también en el lugar de quien los perpetró. Y Miller sostiene que quien juzga imparcialmente actos atroces no debería ocultar sus sentimientos oscuros de repugnancia, porque cumplen un rol más relevante en el orden público y social que en el privado. ${ }^{175}$ Para Nussbaum, en cambio, la repugnancia siempre trae consigo una tensa irracionalidad y deberíamos desconfiar de ella en asuntos de interés público: sean políticas públicas o normas jurídicas.

La posición de Miller, sin embargo es que ciertas emociones morales cumplen un rol válido de protección social dentro de la esfera pública. Refiere el autor que tanto el desprecio, como la humillación y la vergüenza son emociones morales útiles para hacer transparente el estatus de inferioridad y superioridad que causa una opresiva jerarquización en la sociedad y, por esa misma razón, refuerzan el reclamo de respeto entre los seres humanos en el orden político, moral y social. Según Miller, en efecto:

“...más que subvertir a la democracia el desprecio la asiste, al... [hacer visible] una estrategia... de indiferencia en el trato hacia el otro..., entonces, el desprecio viene a reescribir el mínimo respeto básico para las personas, tan crucial para la democracia; el estilo de tolerancia es capturado por el dicho "vive y deja vivir". ${ }^{176}$

El contra-argumento central de Nussbaum respecto de posturas como las de Miller que le asignan una función a la repugnancia en el ámbito público, consiste en demostrar que a diferencia de la ira, la repugnancia no debría ser empleada como persuasión en un discurso público:

"A diferencia de la ira, el asco no le proporciona a la persona asqueada

175 Miller, I., The Anatomy...,obra citada, p. 188-189.

176 Miller, I., The Anatomy..., obra citada, p. 206. 
un número de razones que puedan ser usadas como argumentos y formas públicas de persuasión. Si mi hijo fue asesinado y estoy furiosa por ello, puedo persuadirte para que compartas mis razones y si lo haces, entonces compartirás mi indignación. Pero si alguien siente que los homosexuales son asquerosos, esa persona no puede ofrecer razones que sean capaces de convencer a otro para que comparta esa emoción; no hay nada que pueda convertir a ese diálogo en una persuasión". ${ }^{177}$

Ahora bien, la pregunta que surge es si siempre, y en todos los asuntos de interés público, incluso en los supuestos de políticas públicas para la protección de grupos minoritarios, o desfavorecidos, o para la prevención, identificación, enjuiciamiento y sanción de responsables de crímenes de guerra, de lesa humanidad, genocidios y femicidios es necesario desoír la información que aporta la repugnancia. Ahondaré sobre una respuesta posible a este interrogante, pero específicamente en relación con el derecho y la justicia, en el próximo ítem.

Hasta aquí diré que las emociones morales, sea que se pretenda controlarlas neutralizándolas o erradicándolas, tarde o temprano afloran naturalmente. Entonces, al momento de diseñarse o reformularse políticas públicas sería preciso tenerlas en cuenta y ponerlas en contexto con las áreas de vulnerabilidad que se pretende proteger. En tal sentido, coincido con la postura de Nussbaum que apela al dialogo de las emociones con los principios éticos de autonomía personal, igual valor y dignidad humana y respeto por la diversidad cultural, tan importantes para el progreso social y político y, sobre todo, para el efectivo respeto por los derechos humanos en sociedades que funcionan bajo democracias pluralistas e inclusivas. Incluso, tal criterio debería aplicarse a las emociones "sociales", como la compasión, la simpatía la gratitud porque podrían ser utilizadas para favorecer a alguna persona o grupo de personas en perjuicio de otras. Por consiguiente, lo mismo sucede con la repugnancia, ya que es una emoción cuya legitimidad no debería ser presupuesta; aunque tampoco sería adecuado decir que siempre debe ser desoída, especialmente porque por su contenido cognitivo y evaluativo puede ser importante para enfocar temas de interés público, como lo son los actos de discriminación de minorías y los juicios seguidos por tratos crueles, inhumanos

Emociones bumanas $y$ vida politica, entrevista a Martha Nussbaum, disponible en: http://www.sinpermiso.info/textos/index.php?id=582 
o degradantes. Y este último punto resulta de suma importancia para esta tesis porque, como hemos visto, los jueces en la sentencia condenatoria seleccionada hicieron una referencia explícita a la repugnancia que hubiera causado aplicar una pena menor.

\section{3. "Crímenes Repugnantes"}

Luego de la publicación del libro de Miller, Dan Kahan publicó una reseña crítica del texto en el Journal of Law Review. ${ }^{178}$ La tesis de Kahan fue, a diferencia de Nussbaum, demostrar que la repugnancia cumple un rol central en el derecho criminal, porque ayuda a percibir y condenar la crueldad.

Kahan realizó una distinción importante entre cuatro usos posibles de la repugnancia: la tesis evaluativa, por medio de la cual la repugnancia juzga negativamente su objeto de repulsión, como algo contaminante; la tesis sobre la jerarquización social, a través de la cual la repugnancia establece rangos, comúnmente empleada en políticas públicas que tienen en miras "mantener el orden" y ejercer un poder de policía en la sociedad; la tesis conservadora, que emplea la repugnancia para sostener la desigualdad de clases sociales, con el objeto de conservar una "aristocracia" ya conformada o mantener la distancia entre distintos grupos sociales -aunque las sociedades a las que los mismos pertenecen se autoproclamen como democracias igualitarias-; y finalmente, la tesis de la ambivalencia moral, según la cual necesitamos "indispensablemente" de la repugnancia para marcar nuestro compromiso moral fuerte de empatía con las víctimas de crímenes atroces y motivar la punición de tales actos criminales.

Lo que Kahan sostuvo es que la tesis de la indispensabilidad moral contribuye a reivindicar el valor normativo de la repugnancia en del derecho criminal y que sería apropiado que la persona encargada de juzgar tenga la percepción moral indispensable para sentir repugnancia por aquellos casos "escandalosos, sin motivo, viles, horribles o inhumanos". 179

\footnotetext{
178 Dan M. Kahan, (1998), “The Anatomy of Disgust in Criminal Law”, Michigan Law Review 96, pp. 16211657.

${ }^{179}$ Dan M. Kahan, “The Progressive Appropriation of Disgust”, en Bandes (1999), pp. 63-79.
} 
Por otra parte, y en defensa de su uso en ámbitos públicos, Dan Kahan ha mostrado también que la tesis conservadora explica por qué los grupos minoritarios de las sociedades buscan "progresivamente apropiarse" del lenguaje de la repugnancia antes que aniquilarlo y cómo, consecuentemente, el asco moral pasa a ser un punto central en las políticas públicas de sociedades pluralistas: “...quienes están comprometidos a usar el derecho penal para mejorar la situación de los grupos históricamente desfavorecidos no han repudiado la repugnancia pero la han redirigido apropiadamente hacia sus oponentes". ${ }^{180} \mathrm{El}$ autor se refiere aquí a la posición neo liberal "antirepugnancia", que sostiene que sus teorías liberales sobre el derecho penal deberían estar libres de emociones asociadas a jerarquías, como es el caso del asco moral, puesto que para dicha posición el valor moral de las emociones no puede ser más significativo y constructivo que el valor de una norma social progresista. Contra esta postura, Kahn aduce que el discurso neoliberal del derecho "adormece" al progresismo al oponerse a la consideración de la repugnancia, tornando la situación de vulnerabilidad de los desfavorecidos en mera retórica. ${ }^{181}$

Según Kahan tanto el voluntarismo kantinao como el consecuencialísimo de corte utilitarista, conciben a las emociones desde un punto de vista mecanicista o meramente visceral y es por ello que la repugnancia no puede ser explicada bajo ninguna de dichas posiciones liberales del derecho criminal, puesto que en su discurso omiten o suprimen deliberadamente el significado normativo y el contenido evaluativo que tienen las emociones morales, así sostiene Kahan: "En concreto, las teorías del derecho criminal asociadas con el moderno liberalismo no purgan la repugnancia del derecho. Sólo la ponen por debajo de la norma, donde su influencia es difícil de detectar". ${ }^{182}$ El autor afirma que el voluntarismo busca silenciar la influencia de la repugnancia, mediante la construcción de excusas argumentativas que no dependen de la calidad de la evaluación emocional del perpetrador al momento de los hechos consumados, sino del efecto destructivo de sus emociones, en tanto fue capaz de elegir el

\footnotetext{
${ }^{180}$ Ibíd., p. 70.

181 Ibíd., p. 71. Para un estudio sobre el impacto o influencia de las emociones en la construcción de normas sociales legales, en el área del derecho penal, véase el trabajo de Toni M. Massaro, "Show (some) Emotions", en Bandes (1999), The Passions of Law, pp. 80-120.

182 Kahan, "The Anatomy..., obra citada, p. 1654.
} 
comportamiento a seguir. Y el consecuencialísimo, dice el autor, busca suprimir las apreciaciones evaluativas conectando aquellas excusas con criterios de peligrosidad, impulsividad y desafectación emocional por parte de quien perpetró el delito. ${ }^{183}$

Como bien explica Kahan -y coincido con su perspectiva-, los crímenes atroces nos resultan "repugnantes" y "serios" no sólo porque se ven perjudicados o vulnerados los derechos de otros seres humanos, sino porque reconocemos en ellos que quien llevó a cabo tal acto trasgredió valores humanos y, por ese motivo, se justifica su condena.

Añade Kahan que los debates sobre los denominados "crímenes de odio" étnico, religioso o racial -bajo los cuales estimo que se encuentran comprendidos los crímenes de guerra, de lesa humanidad, genocidios y femicidios-, pueden entenderse mejor si se los enuncia en términos de "crímenes de repugnancia"; que comprende el sentimiento moral que se opone con voz fuerte y visibilidad clara a las atrocidades generadas por la crueldad y, al mismo tiempo, impregna a las normas jurídicas punitivas con mayor potencia para condenar las trasgresiones morales de ese orden que vulneran la dignidad humana. $^{184}$

Como he dicho antes, Martha Nussbaum también se ocupó del rol que la repugnancia desempeña en el derecho. Su idea es que si bien la repugnancia se justifica para delimitar los actos legales de los ilegales, sin embargo debe escudriñarse finamente su confiabilidad intrínseca como base para el derecho. El ejemplo típico que brinda la autora, en alusión al asco moralizado como límite ante actos ilegales, es el de la sodomía o práctica sexual anal que, según ella, se ha censurado históricamente bajo un sentimiento de repugnancia. ${ }^{185}$ Esta fue la posición de Lord Patrick Devlin, en los famosos juicios a Oscar Wilde -condenado por "grosera indecencia" por practicar sexo oral con adultos jóvenes-. Según Devlin: “...la repugnancia social es una fuerte razón a favor de

\footnotetext{
183 Kahan, "The Progressive..., obra citada, p. 72.

184 Para un análisis de emociones negativas tales como repugnancia, humillación, ultraje, desprecio y furia como bases para la construcción social del terrorismo internacional véase el trabajo de Stephen K. Rice, (2009), "Emotions and terrorism research: A case for a social-psychological agenda", Journal of Criminal Justice, 37, pp. 248-255.

185 Martha C, Nussbaum, “Secret Sewers of Vice”, en Bandes (1999), The Passions of Law, pp. 19-62.
} 
la prohibición de un acto, aún cuando no se cause daño a un tercero...”."186

Contra esta postura conservadora de Devlin, la autora construye un argumento fundado en los principios de libertad individual y autonomía personal de John Stuart Mill, que sostiene que ninguna ley de sodomía o restricción a las prácticas sexuales consentidas puede justificarse bajo un criterio de repugnancia moral, mejor, dice ella: “...deberíamos darle sentido a nuestro deseo de vivir juntos en combinación con [principios de] libertad $y$ seguridad....". ${ }^{187}$ Este es un tema que ha sido muy controvertido en el área del derecho penal y que readquiere significación a raíz de la consagración normativa de derechos humanos. Es por ello que, en lo que sigue profundizaré sobre la conveniencia o inconveniencia del uso de la repugnancia en justicia criminal en función del respeto de los principios éticos de igual valor y dignidad humana, autonomía personal y respeto por la diversidad cultural.

\section{Repugnancia, justicia criminal y derechos humanos}

La calificación en la justicia de "crímenes repugnantes" y de personas "criminales repugnantes" resulta jurídica y moralmente problemática en tres sentidos:

1. por las implicancias constitucionales del contenido semántico del término repugnancia;

2. por las implicancias éticas y jurídicas, en torno a la atribución de responsabilidad, que puede acarrear desplazar de la agencia moral a la persona procesada al calificársela como repugnante;

3. por las implicancias morales que genera la ficción de tomar distancia de aquello que nos repugna.

Iremos analizando cada uno los tres supuestos planteados por separado.

Primero: por la vaguedad y constitucionalidad del lenguaje empleado para calificar como "repugnantes" los crímenes atroces en los textos de las sentencias. Dado que no es lo mismo juzgar un homicidio simple, que una tortura seguida de muerte y, por otro lado, dado que no muchos delitos generan

\footnotetext{
${ }^{186}$ Citado por Nussbaum en "Secret Sewers..., obra citada, p. 20.
}

187 Ibíd., p. 45. 
en el público un sentimiento de repugnancia, sería preciso que aquellos que sí lo hacen lo expresen en la sentencia como una agravante de las circunstancias y nunca como una atenuación de la pena, puesto que ello podía poner en riesgo institucional los valores de libertad individual y autonomía personal respecto de las víctimas. Pensemos, por ejemplo, en los casos de homicidios perpetrados en razón del género o en los supuestos de homofobia. Nussbaum distingue entre sí las nociones de obscenidad, peligrosidad y repugnancia que han sido empleadas concomitantemente en algunas sentencias de juicios seguidos en Estados Unidos por ataques sexuales, homofobia, demandas por daños en casos de publicaciones pornográficas no consentidas y por espectáculos o exhibiciones en las que se degrada, humilla y subordina moralmente a la mujer. Al ser pronunciadas por los magistrados para calificar o justificar y atenuar la conducta de quien cometió el crimen, pueden acarrear serios problemas de constitucionalidad en virtud del uso de un lenguaje discriminatorio que también atentaría contra el principio de igual valor y dignidad humana.

Segundo: por el lugar que le asignamos a quien perpetró un hecho atroz, ya que al calificar moralmente a dicha persona como "repugnante" o "monstruosa" la ubicamos por fuera de los límites de su sano juicio y entorpecemos la atribución de responsabilidad jurídica y la aplicación de una justa sanción penal. El argumento principal de Nussbaum aquí es que, al ponderar a quién perpetró un crimen como repugnante, lesionamos su dignidad humana porque no lo consideramos como un ser humano y, por lo tanto, el empleo de la repugnancia en estos casos podría contribuir a reforzar actitudes de auto-indulgencia.

Me extenderé en el análisis de este segundo punto porque presenta varias aristas jurídicas y morales que resuenan directamente en el respeto de los siguientes principios éticos fundamentales para el respeto de los derechos humanos: autonomía personal, igual valor y dignidad humana.

Es cierto que atribuir condiciones patológicas o monstruosas a los individuos que cometen crímenes brutales podría conducir a dichas personas a la autoindulgencia. Y la autoindulgencia conduce a una justificación, poco o 
nada razonable, de actos moral y jurídicamente reprochables, pues la persona que se perdona a sí misma por haber cometido un acto atroz adopta una actitud de inmadurez, que se podría traducir como falta de responsabilidad e inconciencia sobre el alcance de los actos causados al prójimo a quien, con tal actitud, le niega toda posibilidad de arrepentirse, negándose a sí misma, a su vez, la posibilidad de ser perdonada por ello. Es decir que un comportamiento autoindulgente o de autocompasión es un obstáculo en la justicia para una reconciliación de partes, o para el reconocimiento sincero de actos ocasionados; pero no lo es respecto de la atribución de responsabilidad jurídica, puesto que nada entorpece ello si las pruebas de cargo, testimoniales y otras así lo demuestran fehacientemente.

Pero Nussbaum también cree que endilgar atributos de monstruosidad a la persona juzgada por cometer crímenes atroces supone una perversa idea de perfección por parte de quien realiza dicho juicio de valor, que nuevamente atenta contra el principio de igualdad ética entre seres humanos. Ese tipo de calificación patológica y monstruosa sobre la persona criminal ocurrió, por ejemplo, en el caso de Hitler, ya que muchos han explicado el genocidio como consecuencia de su supuesta locura, en lugar de analizarlo en términos de un plan sistemático de exterminio que tuvo causas sociales y económicas perfectamente identificables e imputables. En este sentido, Hitler representa la cara visible y "máscara monstruosa" de una acción humana colectiva, consentida, elegida, con claros propósitos de aniquilación humana; aunque también inaceptable, en términos de aprecio por toda vida de seres semejantes.

Pero, ¿es siempre la calificación de repugnancia causal de autoindulgencia?

La filósofa argentina Arleen Salles, en su artículo "Sobre el asco en la moralidad", hace varias críticas interesantes a la posición de Nussbaum sobre la fiabilidad intrínseca de la repugnancia en la esfera pública y refuta la tesis, sobre la supuesta autoindulgencia derivada de un juicio de repugnancia, que venimos comentando. Afirma que: 
“...el rechazo del comportamiento o de la personalidad moral de otros puede interpretarse de manera diferente, como un reconocimiento de dos cosas: la propia vulnerabilidad y que la inmoralidad admite grados. Respecto de lo primero, hemos visto que es verosímil pensar que el asco moralizado intenta proteger al ser humano de cosas frente a las cuales éste es particularmente vulnerable. Respecto de lo segundo, es importante notar que reconocer la presencia de inmoralidad en otros no implica que uno se conciba sin deficiencias morales. Para ilustrar esto: que $X$ tenga una tendencia a mentir lo hace en parte moralmente deficiente; sin embargo este hecho no invalida moralmente el asco que puede sentir frente al violador sádico o al nazi que habla con indiferencia del exterminio de millones de personas...." 188

Del texto de la autora se desprende que la moralidad y la inmoralidad admiten grados y no implican una actitud de perfeccionismo por parte de quien efectúa un juicio de valor, calificando a otra persona o suceso como "repugnante", pero por ese mismo motivo justifica la jerarquización moral de seres humanos. $Y$, añade Salles que:

“...de hecho, se podría argumentar que algún tipo de jerarquización moral puede ser no sólo moralmente permisible, sino hasta necesaria para mostrar respeto genuino por la agencia moral de las personas, por sus decisiones autónomas y sus acciones. En suma, no está claro que una actitud jerarquizante sea siempre intrínsecamente incorrecta." 189

Haré algunos comentarios sobre esta perspectiva de la autora. Cuando autores como Dan Kahan argumentan a favor de la tesis conservadora de la repugnancia para proteger minorías sociales por medio de políticas públicas, no lo hacen justificando una jerarquización moral sino reconociendo en el plano ético la igualdad entre seres humanos por el simple hecho de ser humano y en el plano material toda una serie de diferencias sociales, económicas, culturales, etc., que nos distinguen individualmente y que, en algunas sociedades, generan o bien una opresión social, o bien una exclusión de dichos grupos al acceso y participación en la vida social y al goce de derechos en un pie de igualdad. Entonces, cuando Kahan dice que las minorías se apropian de la retórica de la repugnancia para redirigirla contra sus oponentes, podríamos pensar que dicha reivindicación tiene en miras reestablecer una desigualdad material mediante acciones afirmativas de discriminación inversa. De tal modo verificamos de qué manera las emociones morales cumplen un rol de protección social cuando son empleadas en las políticas públicas bajo un

\footnotetext{
188 Salles, Arleen, (2010), "Sobre el asco..., obra citada, p. 40.

189 Obra citada, p. 39.
} 
criterio de equidad.

Por consiguiente, considero que efectuar una jerarquización moral de seres humanos en los actos de justicia decisorios resulta incompatible con el respeto del principio de igualdad ética; aunque claramente el juicio de valor que cada quien haga sobre los actos de otras personas, es un juicio que se encuentra exento de dicho discurso público. De hecho, si una autoridad magistral efectuara un juicio de valor sobre la persona que juzga, y no sobre sus actos o sobre la persona en relación directa con el acto en cuestión, se estaría inmiscuyendo en la moralidad ajena y atentaría contra el principio constitucional de autonomía personal. Como hemos visto en la parte primera de esta investigación, la calificación moral intrínseca que se efectúe sobre la persona procesada implicaría una forma simbólica de retribuirle un "mal" que se supone habría causado. Y, según Nino, eso implicaría:

"...una moralización del derecho penal en un sentido que parece inconciliable con una concepción liberal acerca de los límites del poder punitivo estatal... El mal que... debe retribuirse, es entonces un mal moral... Esto conduce... a una intrusión del derecho en la valoración de la personalidad moral de la gente... claramente incompatible con el principio de autonomía de la persona..."190

Nino enfatizaba que el poder coercitivo del estado, cuando es aplicado bajo un esquema retributivo, resulta contradictorio al principio de autonomía de la persona.

Intentaré explicar a continuación cómo la incorporación de la teoría neoestoica sobre las emociones morales, enmarcada en una concepción de justicia respetuosa de los derechos humanos de todas las partes comprometidas en un proceso judicial, plantea un salto cualitativo en torno al modo de reprochar conductas moral y jurídicamente incorrectas en el ámbito de la justicia penal, sin que por ello se vean afectados los principios de autonomía personal y dignidad humana.

¿Se podría dudar acerca de la moralización del derecho penal, cualquiera sea la función punitiva que se adopte, cuando el mismo consiste en censurar y calificar actos contrarios a la ley y también, y en primer lugar,

\footnotetext{
190 Nino, C. S., Ética y Derechos Humanos..., obra citada, pp. 450-451.
} 
contrarios a la dignidad humana?

Sobre este punto, y ante una posible objeción, me gustaría aclarar que reconocer que las emociones aportan argumentos razonables al momento de valorar hechos en la justicia y adoptar una teoría cognitivo-evaluativa no implica una amenaza para el principio de autonomía personal. Ello por cuanto, llegado el caso en concreto, y sin perjuicio que quien juzgue deberá analizar minuciosamente la cuestión inherente a la voluntad de la persona imputada, y si la misma fue viciada, lo que en la justicia penal se analiza es la calidad intrínseca del acto cometido y no la cualidad intrínseca del ser humano.

Cuando hablo de juzgar la calidad intrínseca del acto, no lo hago en abstracto sino que presumo la existencia de sujetos relacionados con tal acto y también de sus estados emocionales al momento de realizar la acción. O sea, en la justicia penal no se juzgará al ser humano por su bondad, maldad, generosidad o egoísmo, por ejemplo, sino que quien juzgue calificará el acto causado en sí, y en relación con quien lo perpetró, teniendo en cuenta las circunstancias de modo, tiempo y lugar de la ocurrencia, pero no se expedirá sobre las cualidades virtuosas o viciosas del actor o de la actora y, en consecuencia, decidirá si quien actuó es o no es responsable por tal acto. Permítaseme precisar con los siguientes ejemplos: si Juan mató al amante de su mujer, un típico acto de emoción violenta basada en celos y envidia, ¿qué importancia tienen las cualidades de Juan por fuera de ese acto o si era un excelente compañero de trabajo e incluso el "marido ideal" ante los ojos de familiares y vecinos? Si Juan lo mató luego de enterarse que su mujer se contagió una enfermedad de transmisión sexual tras mantener relaciones sexuales con aquél, podríamos comprender que además de las emociones mencionadas, Juan podría haber sentido ira y hasta odio por ese hombre y que toda la situación le hubiera sido repugnante. Si acaso Juan hubiera actuado bajo efectos de drogas, incluso, podría atenuarse su sanción porque el conocimiento sobre sus actos se encontraba afectado, pero sería absurdo (y claramente violatorio del principio de autonomía de la persona) agravar su sanción calificando a Juan de "drogadicto". Creo que cuando Nino aludía al riesgo de atentar contra dicho principio constitucional se refería a estos casos en los que la autoridad magistral se desvía del hecho en sí y busca en la 
calidad del agente 0 en sus elecciones personales un "motivo" para sancionarlo. Comprender las emociones morales y considerarlas en las sentencias judiciales, sin embargo, no implica justificar o legitimar hechos aberrantes. Pero pueden aportar argumentos emocionales razonables para atenuar o agravar la sanción penal.

Resumiendo, bajo una concepción liberal del derecho penal respetuosa de los derechos humanos no debería haber injerencia alguna sobre la autonomía de la persona, al menos al momento de la resolución judicial de un caso, que colisione con una justa estimación de las circunstancias emocionales vertidas en un proceso judicial. Y mi posición es que las emociones morales son una herramienta importante para estimar y valorar el caso concreto, y también aportan razones que no deberían ser dejadas de lado.

Por otro lado, es importante hacer algunos comentarios sobre el tema de la supuesta lesión a los principios de igual valor y dignidad humana que implicaría negarle agencia moral a la persona imputada y procesada por cometer actos atroces, al calificársela como "monstruosa" o "repugnante". Como bien indica Salles, la noción de dignidad humana es lo suficientemente ambigua como para ser "utilizada como eslogan moral para poner punto final a la discusión"191 -y Nussbaum no la aclara de manera suficiente- como para ser utilizada como un argumento sin más. Ensayaré aquí una interpretación en clave kantiana.

Cuando Kant construyó su teoría moral y jurídica en base al concepto de dignidad humana, lo hizo sobre la premisa de que todos los seres humanos, por ser humanos, poseemos un valor intrínseco "por encima de todo precio, que no admite equivalente" y que constituye la base para la coexistencia en libertad. Es así como Kant distinguió tres niveles normativos en los que los seres humanos y sus acciones voluntarias se relacionan con el ejercicio interno y externo de su libertad: moral, jurídico y ético. Según Kant, por contraposición a las leyes naturales, se encuentran las leyes morales; las leyes que determinan los motivos para actuar, son las leyes éticas y las leyes que se relacionan meramente con la acción externa y su legalidad, son las leyes

191 Salles, "Sobre el asco..., obra citada, p. 41. 
jurídicas:

“...conformar la voluntad con las normas jurídicas constituye la legalidad de la acción, mientras que conformarla con las normas éticas, constituye la moralidad. La libertad con la cual las normas jurídicas se vinculan sólo puede ser libertad en su ejercicio externo; pero la libertad a la cual se refieren las normas éticas lo es a ambas, a la interna y al ejercicio externo de la de la voluntad...,"192

Consecuentemente, para Kant, lesionar la dignidad de un ser humano es llevar a cabo un acto externo voluntario que viole su libertad, lo cual implica "negarle su capacidad de prestar consentimiento con mi modo de tratarle"; y las normas que protegen los derechos humanos están construidas sobre la base de principios éticos, como son los que venimos analizando.

Pensemos ahora en la noción de dignidad humana dentro de una sociedad democrática, pluralista e inclusiva; cuyos miembros se reconocen éticamente iguales, se han confiado mutuamente el respeto de todos y cada uno de ellos por su libertad individual y diversidad cultural y han acordado protegerse de las afrentas a su dignidad humana mediante el establecimiento de normas coercitivas, que sancionen a quien la autoridad judicial -con un poder soberano delegado republicanamente- adjudique responsabilidad por lesionar derechos humanos. Dentro de este marco, esbozado en la introducción de esta investigación, pensemos ahora en los juicios seguidos en Argentina contra quienes llevaron a cabo crímenes de lesa humanidad durante la última dictadura militar para preguntarnos si esas personas podrían argumentar legítimamente que su dignidad humana ha sido lesionada, o que sus derechos humanos han sido conculcados.

Tengamos presente que si bien los derechos humanos se predican de todos los seres humanos, como condición "necesaria y suficiente para gozar de los derechos en cuestión, en tanto que otras particularidades -raza, sexo, inteligencia, actos cometidos o padecidos, etc.- son irrelevantes", 193 lo cierto es

\footnotetext{
192 Immanuel Kant, (1797), Metaphysical Elements of Justice, Part I of the Metaphysics of Morals, (2nd. Ed.), introducción, notas y traducción de John Ladd, Cambridge: Hackett Publishing Company, 1999, p. 13.

193 Nino, Carlos S., Ética y Derechos humanos, obra citada, p. 41. Entonces, de acuerdo con la definición de Nino, completada a fs. 43-47 de la obra citada,: "...los derechos humanos son derechos morales que se conceden tomando como única propiedad relevante de sus beneficiarios la de pertenecer a la especie bumana, de aqui se infiere que todos [los seres humanos] poseen un titulo igual a esos derechos en la medida en que todos exhiben el mismo grado de esa propiedad relevante... Esto quiere decir que los principios fundamentales de los que los derechos humanos derivan son categóricos, en el
} 
que hay derechos y libertades, como la de movimiento, cuyas condiciones de aplicación son negativas. En efecto, y como bien nos recuerda Nino: “...hay derechos -como el de la libertad de movimientos- que están sujetos a condiciones de aplicación negativas como es la de no comisión de delitos que justificadamente involucren penas privativas de la libertad...". 194 Entonces, fuera de los supuestos en los que desde el poder público judicial se ordena la aplicación de un medida coercitiva consistente en la privación de la libertad, para garantizar que el proceso de investigación y juzgamiento de hechos delictivos se desarrolle dentro del marco de la ley y que su objetivo sea el esclarecimiento y la obtención de la verdad -situación en la efectivamente se suspende la dignidad humana-, las personas que fueron procesadas por la comisión de crímenes de lesa humanidad perpetrados durante la última dictadura militar en Argentina tuvieron derecho a un debido proceso judicial, a una legítima defensa y también a la posibilidad de participar, expresando sus argumentos racionales y sus emociones morales cabalmente, sin que se viera afectada su dignidad humana. En la siguiente sección analizaré con precisión qué valoración sobre los actos y sobre el actor efectuaron las autoridades judiciales en la sentencia condenatoria escogida para aplicar el marco teórico.

Tercero: la expresión de repugnancia dirigida hacia grupos sociales resulta problemática, según Martha Nussbaum, puesto que señala un deseo de tomar una distancia radical de aquello que nos repugna de ese grupo y de lo que "ellos" representan para "nosotros"; tal es el caso de la repugnancia en la misoginia, la homofobia y los genocidios. En éste último supuesto, aclara Nussbaum:

“...cuando pensamos en los Nazis desde un punto de vista
"antropológico"... nos reconfortamos: el mal está afuera,... no tiene
nada que ver con nosotros. Nuestra repugnancia ha creado el límite:
está dicho, esta contaminación es y debe estar lejos de nuestros
cuerpos. Deberíamos asimismo decir en este caso nuevamente, que
llamamos a la repugnancia en nuestra ayuda: permitiéndonos a
nosotros mismos ver a la gente malvada como repugnante, los
distanciamos convenientemente de nosotros mismos... en cambio,
cuando vemos a los Nazis representados sin repugnancia, como seres

sentido de que ellos no condicionan la titularidad de tales derechos a la posesión de una u otra característica... son erga omnes... uno es el principio de inviolabilidad de la persona... el segundo principio es el de autonomía de la persona... el tercer principio, el de dignidad de la persona...".

194 Obra citada, p. 41. 
humanos con características comunes a las nuestras... es alarmante, porque ello requiere que hagamos un auto escrutinio, nos advierte que podríamos haber hecho lo mismo bajo circunstancias semejantes. Nos alerta de la presencia del mal en nosotros...". ${ }^{195}$

En tal sentido, lo que la autora quiere resaltar en este punto es que pretender separar a "ellos" de "nosotros", ubicando la "vileza" de por medio, implica una negación de la maldad en nuestra propia humanidad.

Por otra parte, y teniendo en cuenta lo hasta aquí desarrollado, podemos afirmar que dentro del derecho criminal podemos encontrar, al menos, dos perspectivas válidas que involucran la consideración de la repugnancia en la justicia:

a. La "repugnancia" que sintió una persona y que alega como una provocación razonable que la motivó a perpetrar un acto particular, posteriormente calificado por la justicia como ultrajante;

b. La repugnancia que experimenta la persona encargada de juzgar crímenes de guerra, de lesa humanidad, genocidios y femicidios.

En el caso "a", se apela a la emoción de repugnancia para obtener una reducción en la condena, esto es, para morigerar los alcances de la punición que, sin lugar a dudas, será atribuida a quien perpetró un hecho en clara trasgresión a las normas del derecho criminal. Dicha apelación puede resultar una simple estrategia o manipulación argumental de defensa, o bien puede tener un viso de veracidad, proveniente del propio relato sincero de la persona ofensora, analizado en conjunto con pericias psíquicas que den cuenta de su perfil psíquico-emotivo, de su capacidad de razonar sobre los hechos por los cuales dicha persona ha sido juzgada y de su nivel de consciencia sobre las consecuencias dañosas de los hechos perpetrados, no sólo respecto de su o sus víctimas, sino que también de la sociedad en su conjunto, e, incluso de su comprensión acerca del alcance autodestructivo que el hecho ha tenido para su persona; todo lo cual debería ser profunda y transparentemente indagado por la instrucción judicial que intervenga para colaborar eficazmente con la posterior decisión judicial. Por otra parte, la justicia podrá variar la calificación legal, mitigar o agravar la condena, sin que ello implique una justificación de los hechos horrorosos, sino más bien la comprensión acabada de su ocurrencia en

195 Nussbaum, M., “Secret Sewers..., obra citada, p. 51-52. 
las circunstancias de modo, tiempo, lugar y estado emocional preciso de la persona perpetradora al tiempo de la comisión de los mismos.

Nussbaum analiza este tipo de casos en los que se suele alegar repugnancia como respuesta a una provocación por parte de la víctima, que experimentaría un ser humano "razonable". En su opinión no se trataría de un caso de repugnancia sino de ira, cuya consecuencia es el daño:

“...la repugnancia parece distinta de la ira, en el sentido de que es una respuesta generalizada a la presencia de ciertas características de una persona, no a un acto agresivo o injusto de una persona... Ser repugnante no es una invitación a la violencia... es frecuentemente el resultado de prejuicios aprendidos socialmente, de modo que al mitigar la pena sobe la base de la repugnancia estaríamos reduciendo la disuasión para los crímenes motivados por el odio a determinados grupos de personas...". 196

Una primera conclusión de la autora, es que el derecho debería tener más en cuenta el factor repugnancia hacia objetos primarios de contacto pero no como criterio de repugnancia proyectiva sobre individuos o grupos vulnerables. Nussbaum se refiere a esto último en términos de "repugnancia constructiva" puesto que todo el "asco moral" proviene de una elucubración de la mente de quien se repugna, sin que haya una agresión o acto hostil externo, siendo todo ello una excusa defensiva para justificar la violencia.

Esta distinción de Nussbaum es interesante, pero no alcanza a demostrarla de manera clara, ni tampoco a mostrar que el sentimiento de repugnancia sea siempre una elucubración de la mente de quien se repugna y que esa elucubración no tenga un correlato hostil externo.

Otro punto que tiene en cuenta la autora es que algo repugnante no constituye una provocación suficiente (del tipo de una justificada autodefensa ante una agresión violenta por parte de la víctima). Lo que ciertamente puede alegarse en el supuesto de la ira. Es posible que Nussbaum esté en lo cierto al considerar que el ser humano que siente repugnancia por otro individuo o minoría étnica, religiosa, racial o de otra índole, siente un profundo desagrado por sus cualidades intrínsecas, por sus características fisonómicas o por sus prácticas culturales y ello es así, independientemente de la existencia una

\footnotetext{
196 Nussbaum, M., El Ocultamiento..., obra citada, p. 153.
} 
relación personal o ni siquiera casual entre ambos. Parecería entonces que la repugnancia sentida por alguien o por algunas personas es algo que no conduciría a una reacción violenta, sino más bien al distanciamiento humano de esa persona o grupo. Ante la repugnancia, el mecanismo defensivo suele ser la evasión, de modo que no serviría de excusa, prima facie, para el perpetrador de una acción violenta.

En el caso "b", son las autoridades judiciales quienes apelan a un sentimiento de repugnancia. Aquí situamos el juicio imparcial descripto por Adam Smith, que se opone a la noción de juicio neutral o libre de sentimientos. En Justicia Poética (1995), Nussbaum adoptaba una perspectiva kantiana y aristotélica del ser humano, contraponiéndola a la corriente utilitarista y le asignaba un rol preponderante a la imaginación, como vehículo para el desarrollo bien fundado en la composición de un juicio público puesto que la imaginación, como ya vimos, nos permite "empatizar" con las emociones de las personas juzgadas. En tal sentido expresaba Nussbaum que: "una ética de respeto imparcial por la dignidad humana no logrará comprometer a seres humanos reales a menos que estos sean capaces de participar imaginativamente en la vida de otros, y de tener emociones relacionadas con esa participación". ${ }^{197}$

Tomando un poema de Whitman de Hojas de Hierba, "En la Orilla del Ontario Azul”, la autora construyó el arquetipo de poeta-juez, capaz de iluminar todos los aspectos humanos, en contraposición con la denominada "racionalidad judicial" que antepone neutralidad y escepticismo para reducir el juicio a lo políticamente correcto, en una visión casi científica de los seres humanos que no tiene en cuenta el papel que juegan las emociones en la racionalidad pública. Pero su posición sobre el asco moralizado no ha cambiado. De hecho, en El Ocultamiento de lo Humano, la autora calificó de confusa la postura de Kahan que reivindica la expresión de repugnancia en la justicia ante crímenes atroces, puesto que según ella, la repugnancia sirve para exponer que la persona que comete un delito es intrínsecamente "vil y rastrera"

\footnotetext{
197 Martha C. Nussbaum, (1995), Poetic Justice. The Literary imagination and the Public Life, traducción de Carlos Gardini, Santiago de Chile: Editorial Andrés Bello, 1997, p. 18.
} 
y no para evaluar el daño que causó su acto. ${ }^{198}$

Resumiendo, teniendo en cuenta que las apreciaciones y creencias que contiene la repugnancia constituyen una base para la discriminación y que, por lo tanto, resulta ser una emoción controvertida para la construcción de normas jurídicas y políticas públicas respetuosas de los derechos humanos, estimo que sólo resultaría plausible su invocación en la justicia, al momento de sentenciar, cuando sea expresada en relación con crímenes atroces en los que se encuentre gravemente comprometida la dignidad humana de las víctimas; siendo inconciliable con el respeto de los derechos humanos su uso en la justicia para calificar a las partes o testigos intrínsecamente, esto es, por fuera de los crímenes controvertidos. En tanto ser humano encargado de juzgar ética y jurídicamente hechos aberrantes, la autoridad judicial al aportar en el fallo sus sentimientos morales de empatía con el sufrimiento de las víctimas, lejos de teñir de parcialidad el juicio lo ubica en el lugar público de condena social.

198 Nussbaum, M., El Ocultamiento de lo Humano..., obra citada, pp. 104-106. 


\section{Sección II: Análisis de la Sentencia}

\section{Presentación de la sentencia elegida}

El veredicto del fallo que pasaremos a analizar fue emitido oralmente, en fecha 19 de septiembre de 2006, por el Juez Carlos Alberto Rozanski, entonces presidente del Tribunal Oral en lo Criminal Federal Nro. 1 con asiento en la ciudad de La Plata y los fundamentos de la sentencia fueron leídos públicamente en el palacio municipal de dicha localidad el 26 de septiembre de ese año.

A sus 77 años de edad, el Comisario Retirado, Miguel Osvaldo Etchecolatz, en su carácter de responsable de la Dirección General de Investigaciones de la Policía de la Provincia de Buenos Aires durante el período comprendido entre los meses de mayo de 1976 y enero de 1979, resultó condenado "por delitos de lesa humanidad, cometidos en el marco del genocidio que tuvo lugar en la República Argentina entre los años 1976 y $1983^{\text {"199 }}$ con pena de reclusión perpetua e inhabilitación absoluta perpetua por considerárselo coautor penalmente responsable del delito de homicidio calificado en perjuicio de Diana Esmeralda Teruggi; autor mediato penalmente responsable de los delitos de privación ilegal de la libertad calificada, aplicación de tormentos y homicidio calificado de Patricia Graciela Dell'Orto, Ambrosio Francisco De Marco, Elena Arce Sahores, Nora Livia Formiga y Margarita Delgado; y autor penalmente responsable de los delitos de privación ilegal de la libertad calificada y autor mediato penalmente responsable de la aplicación de tormentos en perjuicio de Nilda Emma Eloy y Jorge Julio López, disponiéndose su alojamiento en una penitenciaría común situada en la localidad de Marcos Paz, provincia de Buenos Aires.

Es dable mencionar que el 18 de septiembre de 2006, o sea un día

199 Así expresa el veredicto en el último párrafo del apartado “d” de su segundo punto resolutorio. 
antes de la lectura del veredicto, fue la última fecha que se tuvo noticias de Jorge Julio López, una de las dos víctimas sobrevivientes y testigo clave del juicio quien, en palabras del entonces gobernador de la provincia de Buenos Aires, Felipe Solá, fue el "primer desaparecido en democracia". ${ }^{200}$ López hasta el presente sigue sin aparecer.

Este fallo célebre a nivel institucional, sentó un precedente en materia de respeto por el sistema internacional de protección de los derechos humanos al juzgar por delitos de lesa humanidad a un ex agente de seguridad del estado y establecer que dichos actos atroces fueron cometidos en el marco del "genocidio" ocurrido en Argentina entre los años 1976 y 1983, tal como fue entendido por los jueces de la causa.

\title{
2. Aniquilación y Limpieza ideológica
}

En la sentencia, los magistrados resaltaron y transcribieron las siguientes manifestaciones formuladas por la defensa de Etchecolatz, que a mi entender implican un reconocimiento expreso del mandato "legal" que los agentes de seguridad del estado tenían para exterminar y aniquilar en todo el territorio "nacional" a quienes resultaran subversivos en caso de "necesidad":

\begin{abstract}
"Remarcaron finalmente el Decreto 2772/75 que establece que las Fuerzas Armadas procederán a ejecutar las operaciones que sean necesarias a los efectos de aniquilar los elementos subversivos en todo el país, aclarando que "para que no queden dudas, la palabra aniquilar según el diccionario es destruir o arruinar eternamente, no es agradable y por eso no hay que provocarlas..."
\end{abstract}

Podemos deducir de dicho texto que la mera adhesión a ideologías diferentes que las del gobierno de facto implicaba una "provocación" suficiente, que habilitaba a las Fuerzas Armadas y a todas las fuerzas de seguridad del estado a aniquilar seres humanos, considerados por el régimen como "elementos subversivos", en todo el país.

\footnotetext{
200 Ver, por ejemplo, notas de prensa, del 26 de septiembre de 2006, en los siguientes diarios locales: Clarín, "ES UN HECHO GRAVÍSIMO PARA LA DEMOCRACIA", DIJO EL GOBERNADOR: http://old.clarin.com/diario/2006/09/26/elpais/p-00501.htm; Página/12, FELIPE SOLA ATRIBUYO EL SECUESTRO DE LOPEZ A SU DECLARACION JUDICIAL: "ESTO NO ES UNA DESAPARICIÓN CUALQUIERA": http://www.pagina12.com.ar/diario/elpais/1-73579-2006-09-26.html y La Nación, A UNA SEMANA DE LA CONDENA A ETCHECOLATZ SOLÁ DIJO QUE EL TESTIGO "ES EL PRIMER DESAPARECIDO EN DEMOCRACIA": http://www.lanacion.com.ar/nota.asp?nota id=843594.
} 
Aunque el crimen de genocidio y las atrocidades conexas al mismo no constituyen el objeto específico de esta investigación, sino el rol que las emociones morales desempeñan en la justicia sobre todo en el marco de crímenes horrorosos, resulta relevante comentar que en el caso bajo examen, Etchecolatz no fue hallado penalmente responsable por el delito internacional de genocidio sino por haber cometido crímenes de lesa humanidad en dicho contexto. $^{201}$

La calificación que han efectuado los jueces de "genocida"202 respecto de la última dictadura militar en Argentina, con base en la existencia de un "plan sistemático de exterminio", ha generado una polémica ${ }^{203}$ que nos permite hacer la siguiente reinterpretación para introducirnos en el tema:

Si bien los antecedentes de la Convención para la Prevención y Sanción del Genocidio, tal como lo advirtió el juez de la causa, preveían grupos o motivos políticos como foco del crimen de genocidio, dichas expresiones fueron posteriormente suprimidas del texto definitivo. ${ }^{204}$ El objeto de protección normativa de dicha Convención es el derecho a la vida y a la existencia de grupos humanos minoritarios y los sujetos protegidos resultan ser, restrictiva y taxativamente, seres humanos con identidad étnica, racial, religiosa o nacional, quedando fuera de dicha norma los movimientos políticos. Consecuentemente, quedarían jurídicamente excluidas de la atribución de responsabilidad penal

\footnotetext{
201 Para profundizar sobre concepción del crimen de genocidio, su tensión con otros crímenes contra la humanidad y el debate en torno a las posibles lagunas jurídicas por los denominados "genocidios culturales"dentro de los que se podrían incluir las prácticas de limpieza étnica-, se puede consultar, por ejemplo, el documento: "What is Genocide? What are the Gaps in the Convention? How to Prevent Genocide?", presentado por William A. Schabas en el Foro Regional sobre Prevención del Genocidio realizado en Buenos Aires, del 10 al 12 de diciembre de 2008. Disponible en: http://www.cancilleria.gov.ar/portal/dighu/docs/william_schabas.pdf

${ }^{202}$ Los magistrados al sostener tal postura tuvieron en consideración la causas nacionales Nro. 13/84, por medio de la que se juzgó a los ex integrantes de las juntas militares de Argentina en cuya sentencia se aludió a la mecánica de destrucción masiva instrumentada por el "Proceso de Reorganización Nacional" y Nro. 44/86 en la se aludió a un "plan de exterminio", así como el avance jurisprudencial al respecto de la justicia española en la causa que se condenó a Adolfo Francisco Scilingo Manzorro, en la se describieron los hechos ocurridos en Argentina como consistes en la persecución, hostigamiento, detención ilegal, tortura, desaparición de personas y exterminio contra un grupo "contrario al régimen", todo lo cual fue considerado un genocidio.

${ }^{203}$ Sobre la polémica en torno a la exclusión de los movimientos políticos, del tipo penal del crimen de genocidio, véase por ejemplo la nota "El Genocidio Argentino", por Santiago O'Donnell en: http://www.pagina12.com.ar/diario/elmundo/4-94050-2007-11-04.html

204 Véase la Resolución 96 I de la Asamblea General de las Naciones Unidas en: http://daccess-ddsny.un.org/doc/RESOLUTION/GEN/NR0/033/47/IMG/NR003347.pdf?OpenElement y el Estatuto del Tribunal Militar Internacional de Nuremberg que preveía también, entre los crímenes de lesa humanidad, a la persecución por motivos políticos.
} 
individual y de responsabilidad estatal internacional por el crimen de genocidio las personas y los Estados partes de la Convención, aún cuando se verificase la existencia de una política o plan de policía de un gobierno de persecución ideológica, salvo que dicho plan evidencie la intención de exterminio; criterio adoptado, en fecha 5 de julio de 2001, por el Tribunal Internacional para la ex Yugoslavia en el caso seguido contra Goran Jelisic. ${ }^{205}$

El fallo que emitió la Corte Internacional de Justicia, el 26 febrero del año 2007, para evaluar la aplicación de la mentada convención en el caso Bosnia y Herzegovina c/ Serbia y Montenegro, ${ }^{206}$ revisó el concepto de genocidio en relación con la denominada "limpieza étnica" y sostuvo que ni la intención de un gobierno ni una política o práctica tendiente a homogeneizar la población étnica en un territorio constituyen en sí un delito de genocidio, a menos que el sometimiento del grupo, en sus condiciones físicas y psíquicas de existencia, atente contra su destrucción total o parcial. ${ }^{207}$

He llegado a este punto, puesto que la noción de "limpieza étnica" traída por la Corte Internacional de Justicia me permitirá afirmar y argumentar, dentro del marco teórico establecido y, concretamente, en relación con la repugnancia, que en Argentina se cometieron crímenes de lesa humanidad en el contexto de una "limpieza ideológica" contra marxistas, ateos, religiosos reformistas y personas con afiliación a movimientos políticos de izquierda en general.

En tal sentido, resulta destacable el voto de adhesión a la condena de Etchecolatz del Dr. Horacio Alfredo Insaurralde, quien efectuó una autocrítica en relación al rol que el poder judicial desempeñó en la época de los hechos, manifestando que no ejerció el debido control y permitió el ocultamiento de información por parte de las Fuerzas Armadas, que llevaron adelante un plan sistemático de represión, clandestinidad y exterminio contra toda “manifestación intelectual opositora” constituyendo ello, para el magistrado,

\footnotetext{
205 Véase: http://www.icty.org/sid/7972

206 El resumen del fallo, emitido en fecha 26 de febrero de 2007, se puede consultar en: http://www.icjcij.org/docket $/$ index.php? sum $=667 \&$ code $=$ bhy\&p $1=3 \& p 2=2 \&$ case $=91 \& \mathrm{k}=\mathrm{f} 4 \& p 3=5$. Ver párrafos 142201.

${ }^{207}$ La noción de limpieza étnica se conjuga con la de genocidio cuando la práctica tiene por objetivo algo más que el desplazamiento o sometimiento de un grupo, cuando la intención concreta es su exterminio. Léase por ejemplo: "Limpieza Étnica en la ex-Yugoslavia" de Muhamedin Kullashi, traducido por Vilma Penagos, en Revista Praxis Filosófica, No. 16, enero-junio 2003, pp. 78-107.
} 
un genocidio. Así dijo:

"Toda esta actividad se desarrollaba sistemáticamente, y estaba destinada al exterminio de toda persona que se sospechara como perteneciente a la oposición al régimen de facto, no sólo a la conducta de grupos armados ofensivos o de resistencia, sino a toda manifestación de vida independiente intelectual, tácita o implícitamente opositora, o a toda aquélla que no denotara sumisión ciega a la actividad del Estado usurpado por un gobierno militar de facto."

Purgar a la sociedad de "células subversivas" fue el plan. La frase claramente tiene connotaciones que van más allá del desprecio. El mensaje podría leerse como "eliminemos a los zurdos", por ejemplo, a quienes bajo una idea de repugnancia se los habría considerado como "elementos" (células) dañinos o contaminantes para la sociedad. Las ideas de desacato a lo socialmente correcto de esa época se vinculan con una adjudicada pretensión de subversión de valores por parte del grupo "contrario" al régimen. Ello marca claramente estatus de jerarquías: ${ }^{208}$ inferior para los subversivos y superior para los agentes de seguridad del estado quienes, en orden de dependencia laboral, se veían conminados políticamente -despóticamente- a identificar, perseguir, privar ilegítimamente de la libertad, torturar y en lo posible eliminar toda huella de quienes fueran una amenaza suficiente para la instauración del nuevo "orden". 209

Ideas de purga, limpieza o eliminación, propias de la percepción moral de una sociedad que se siente impura o contaminada, encajan perfectamente con las prácticas de desaparición forzada de personas, que formaron parte del autodenominado "Proceso de Reorganización Nacional" por parte de las Juntas Militares que derrocaron el gobierno constitucional de María Estela de Perón el 24 de marzo de 1976. Así lo reflejó el juez de la causa al transcribir en la sentencia el auto de procesamiento, respecto de 98 militares argentinos, efectuado por el magistrado español Baltazar Garzón; escrito en el que se

\footnotetext{
${ }^{208}$ El efecto social jerarquizante de la repugnancia fue descripto en la Parte Segunda, Sección Primera, punto 2.

${ }^{209}$ Los jueces valoraron en la sentencia positivamente la colaboración de la testigo Claudia Bellingeri, quien aportó: "datos importantes respecto del funcionamiento de las dependencias de la Policía de la Provincia de Buenos Aires y el rol en la actividad ilegal investigada en esta causa, entre ellas, la Dirección de Investigaciones al mando del imputado" y estableció que el modus operandi consistía en identificar y perseguir estudiantes, religiosos reformistas y militantes que eran fichados alfabéticamente y calificados como "subversivos", "guerrilleros" o "extremistas". Aclarando que en las fichas no obraban datos de jueces ni fiscales y que cuando dichas autoridades solicitaban información, tenían ordenes de armar un expediente por "Averiguación de Paradero" e informar que no habían datos sobre la persona en cuestión, aún cuando se supiera dónde estaba detenida o si ya estaba muerta.
} 
pueden advertir palmarias alusiones a la idea de "limpieza ideológica:

\begin{abstract}
"En Argentina las Juntas Militares imponen en marzo de 1976, con el Golpe de Estado, un régimen de terror basado en la eliminación calculada y sistemática desde el Estado, a lo largo de varios años, y disfrazada bajo la denominación de guerra contra la subversión, de miles de personas... en forma violenta. La finalidad de la dicha acción sistemática es conseguir la instauración de un nuevo orden como en Alemania pretendía Hitler en el que no cabían determinadas clases de personas, aquellas que no encajaban en el cliché establecido.... Es decir, todos aquellos que, según la Jerarquía dominante, no defendían un concepto de ultranacionalismo de corte fascista de la sociedad, obedeciendo a "consignas internacionales como el marxismo o el ateísmo". En función de este planteamiento se elaboró todo un plan de "eliminación selectiva" o por sectores de población integrantes del pueblo argentino, de modo que puede afirmarse, que la selección no fue tanto como personas concretas, ya que hicieron desaparecer o mataron a miles de ellas sin ningún tipo de acepción política o ideológica, como por su integración en determinados colectivos, Sectores o Grupos de la Nación Argentina, (Grupo Nacional) a los que en su inconcebible dinámica criminal, consideraban contrarios al Proceso. ... El objetivo de esta selección, arbitrario en cuanto a las personas individuales, estuvo perfectamente calculado si se pone en relación con lo que era el objetivo del denominado "Proceso de Reorganización Nacional" basado en la desaparición "necesaria" de determinada "cantidad" de personas ubicadas en aquellos sectores que estorbaban a la configuración ideal de la nueva Nación Argentina. Eran "los enemigos del alma argentina", así los denominaba el General Luciano Benjamín Menéndez, imputado en esta Causa, que, por alterar el equilibrio debían ser eliminados". ${ }^{210}$
\end{abstract}

En esta caracterización de los hechos ocurridos en Argentina durante la última dictadura militar efectuada por el juez español Baltazar Garzón, se observan varias ideas implícitas de repugnancia. La alusión a la alteración del equilibrio social, traducida en el pensamiento militar de aquella época, podría interpretarse como el motivo suficiente que los militares tenían para proceder a la selectiva extirpación, mediante prácticas de desaparición forzada, de todas aquellas personas que formaran parte de grupos sociales o políticos que fueran considerados un "estorbo" o un "adversario" para el "nuevo orden" que se pretendía instaurar. La selección, como precisa el juez, fue sistemática en todo el territorio del estado y el criterio adoptado tuvo en cuenta el factor ideológico: erradicar a todos los miembros de aquellas organizaciones que, en general, respondieran al espectro político de la izquierda, cuya posición fuera inconveniente, en términos políticos y sociales, para llevar adelante el plan.

\footnotetext{
${ }^{210}$ Se lo puede consultar en: http://www.nuncamas.org/juicios/espania/espania 021199 04.htm
} 
Como bien explicaba Baltazar Garzón, la persecución fue discriminada por organizaciones políticamente inconvenientes al régimen e indiscriminada en relación a las personas que formaban parte de dichos colectivos.

Por otra parte, la frase "enemigo del alma", denota algo más que un simple adversario. Puesto que esos grupos tenían el poder de llegar a tocar el alma del nuevo orden que se pretendía imponer, pareciera que, en mente de aquellos perseguidores, esa "alma" se oscurecía, se tornaba impura: había que librar una guerra "sucia". Nuevamente aquí podemos afirmar que la idea simbólica de impureza en el alma, expresada por ex agentes de seguridad del estado, nos está hablando de repugnancia moral. Pareciera entonces descansar, detrás de ésta práctica de "limpieza ideológica", una idea atomista puesto que, ante la menor duda, se elegía extirpar al "órgano" contaminado directamente, consistiendo la táctica en rastrear y eliminar a todos sus componentes.

La intención, en el crimen de genocidio, es la exterminación de un grupo minoritario con características comunes de etnicidad, nacionalidad, religión o raza, haya o no desplazamientos, haya o no planes formales que lo sustenten. Por otra parte, la emoción que yace tras el deseo de exterminar es el odio, basado en creencias valorativas (prejuicios) respecto de la etnia, nacionalidad, religión o raza del grupo odiado. ${ }^{211}$ Como ya hemos visto, quien odia desea que "desaparezca" su objeto formal de conocimiento, sean cosas, sujetos o ideas.

¿Cómo se conjuga el odio genocida con la limpieza ideológica?

La práctica consistente en la limpieza ideológica podría configurar el delito de genocidio, siempre que el objetivo uniforme y firme de aquella fuera el exterminio humano. Pero es preciso analizarlo cuidadosamente puesto que tras la repugnancia, que engloba una práctica de "limpieza" humana, hay un deseo de degradación y tras el odio, de destrucción, estableciendo ambas emociones

\footnotetext{
211 Véase por ejemplo en la Parte Primera, Sección Primera, el punto que trata sobre el rol de las emociones en la esfera pública. Tomo el concepto de odio, brindado por Aristóteles en Retórica (1382a), quien expresaba que quien se encuentra iracundo quiere que su ira se manifieste, pero quien odia ni sufre, ni se conmueve, el primero quiere que su enojo hacia el otro se convierta en venganza, en cambio quien odia quiere que el otro deje de existir. Por otra parte, entiendo que quien se repugna sostiene un estatus de inequidad social en el que la emoción le permite conservar su jerarquía de superioridad, mientras que quien odia sostiene un resentimiento basado en el repudio intrínseco por la igualdad que otro ser humano le refleja.
} 
sendas diferencias en torno al cruento sufrimiento de las víctimas: pareciera ser que en el supuesto de la repugnancia habría cierto goce del padecimiento ajeno que es preciso que la víctima atestigüe, y en el caso del odio que también existe un goce envilecido pero centrado en el victimario sin importar la víctima, que resulta un mero objetivo de eliminación.

Hecho este primer abordaje, a continuación identificaré qué emociones morales expresadas por los distintos actores del proceso judicial: víctimas, victimario y testigos se reflejaron en la sentencia condenatoria de Etchecolatz, luego observaré qué valoración se efectuó eventualmente sobre las mismas y, en la medida de lo posible, evaluaré su compatibilidad con el respeto de los derechos humanos.

\section{Emociones en los relatos de víctimas, victimario y testigos}

En el Punto 2 de la Sentencia, denominado Prueba, los jueces incluyeron una descripción de los relatos de víctimas y testigos conforme fueron acreditando los cinco delitos ya mencionados que se le atribuyeron a Etchecolatz, habiéndose tenido en cuenta algunos testimonios en más de un delito probado. Es dable destacar también, que los jueces profundizaron la descripción de la narración de los hechos efectuada por las víctimas por sobre la de los testigos, las que fueron sucintamente reducidas en la sentencia limitándolas a lo que condujera a probar cada uno de los delitos en cuestión.

En lo que concierne a la aplicación del marco teórico escogido, me concentraré en la descripción detallada de los relatos de las dos víctimas sobrevivientes: Nilda Emma Eloy y Jorge Julio López y en la correspondiente valoración efectuada por las autoridades judiciales que intervinieron en el caso. También mencionaré y analizaré algunos aspectos pertinentes con el objeto de la investigación de otros testimonios. ${ }^{212}$

Nilda Emma Eloy fue secuestrada del domicilio de sus padres (quienes resultaron golpeados y cuyo hogar fue "saqueado" en dicha ocasión y a los tres

\footnotetext{
212 Todas las citas entre comillas y en cursiva que figuran a continuación se encuentran trascriptas de la sentencia condenatoria de Miguel Ángel Etchecolatz.
} 
día siguientes) por un grupo armado sin uniformes al mando del entonces Comisario Etchecolatz, en la madrugada de 1 de octubre de 1976. Aquella noche, el grupo ingresó en su habitación obligándola a vestirse, luego le vendaron los ojos, la tiraron en la parte trasera de un vehículo y la trasladaron a un centro clandestino de detención ubicado en la localidad de Avellaneda, provincia de Buenos Aires, en el que fue desvestida, golpeada y torturada mediante la aplicación de "picana eléctrica", ${ }^{213}$ reconociendo en la "sala de torturas" la voz de un hombre conocido de su madre. Relató que luego la trasladaron a una sala en la que un "sacerdote", a quien apodaban "Manolete", pisó sus manos. Luego la subieron a un camión con mucha gente, que efectuó una parada en la que obligaron a todos a arrodillarse en un "simulacro de fusilamiento" y siguió camino hasta otro centro clandestino ubicado en Quilmes, provincia de Buenos Aires. Allí reconoció a sus amigas por la voz, quienes la ayudaron a sacarse la venda de los ojos, oportunidad en la que pudo observar todo su cuerpo ennegrecido, quemado por la picana eléctrica. Sostuvo que el médico que la visitaba en el calabozo le pasaba un ungüento por las heridas, al mismo tiempo la "manoseaba". Refirió que fue trasladada a otro centro de detención y luego a otro más ubicado en la localidad de Lanús, provincia de Buenos Aires, al que los agentes denominaban "el infierno". Allí estuvo encerrada por cinco días, junto a seis personas más en un calabozo de mínimas dimensiones (1.5 por $2.0 \mathrm{mts}$.) en el que los guardias insertaban una manguera por la puerta para mojarlos, recibiendo una cucharada de comida sólida cada diez días aproximadamente. Relató que la torturaban para que sus gritos aterraran a otras detenidas y sugirió haber tenido relaciones sexuales a cambio de obtener la puerta de su calabozo abierta, lo que le permitía respirar y eventualmente conseguir algo de agua "en un zapato" para saciar la sed. Llegó a pesar 29 kilos. El régimen de visitas para quienes tenían contacto con sus familiares era limitado y en su caso sentía "desesperación" porque: "no figuraba en ningún lado, pasaban los meses y ella no figuraba, no existía”. En Lanús observó que traían: "restos humanos para "limpiar", eran cráneos y

\footnotetext{
${ }^{213}$ En fecha 23 de junio de 2006 el diario "Pagina/12" publicó una crónica referida al testimonio brindado por Nilda Emma Eloy y lo desgarrador que resultó para ella reconocer a uno de sus torturadores en el proceso judicial, que tituló "EN EL FONDO DE LA DEGRADACIÓN HUMANA. NILDA ELOY RECONOCIÓ A SU TORTURADOR EN LA PANTALLA DE TELEVISIÓN DESPUÉS DE CASI VEINTE AÑOS": http://www.pagina12.com.ar/diario/elpais/1-68904-2006-06-23.html
} 
manos, aclarando que limpiar era sacar todo el resto de tejido hasta que quedaran huesos", y ella, como se había recibido de instrumentadora quirúrgica, junto con un médico cirujano recibió material y fue sometida a hacer ese trabajo, lo cual le permitió recibir luz solar. Manifestó que luego fue trasladada a la cárcel de Devoto, provincia de Buenos Aires, sitio dónde varias personas pasaban a la legalidad, y previa aprobación del Jefe Departamental eran puestas a disposición de alguna autoridad judicial para obtener su libertad. A principios de 1979 fue liberada.

Las autoridades remarcaron las siguientes expresiones vertidas por la víctima: "todo estaba preparado para que uno se cosificara, habían perdido su nombre, su relación con el día, la hora, el tiempo, ahí adentro siempre hacía frío, era como si fuera un túnel continuo, a pesar de los traslados era siempre lo mismo".

Si bien de la descripción de los hechos de esta testigo, los jueces resaltaron su desesperación y las sensaciones de frío y pérdida de la noción del tiempo y del espacio, reflejaron escasas emociones morales vinculadas con las atroces vulneraciones a la dignidad humana que padeció Nilda Emma Eloy. En tal sentido, en el apartado "a" denominado "Delitos de Lesa Humanidad", dentro del punto referido a la "Calificación Legal", los jueces destacaron que la testigo fue degradada tanto física como espiritualmente: "con la naturalidad y el desprecio por el tejido vivo con que sólo los hombres más crueles pueden actuar".

No hay menciones al pudor o la vergüenza que pudo haber sentido respecto de sus reiterados estados de desnudez; ni a la humillación que pudo haber experimentado ante las constantes vejaciones sexuales, incluidas las descargas eléctricas en su vagina, sugeridas en su relato. En consecuencia no se vislumbra en el fallo un análisis de género, respecto de los derechos humanos vulnerados a Nilda Emma en tanto mujer. Tampoco se observa un análisis del impacto psíquico que dichos atentados a su integridad física representaban para su salud. Es de imaginar que si su peso llegó a los 29 kilogramos, su estado mental, físico y emocional se vio también devaluado, cuestiones que no fueron analizadas en términos de vulneración a los derechos humanos a la alimentación, higiene, salud y respeto por su dignidad humana, 
aunque se efectúen menciones genéricas a las "condiciones de detención". Aunque hacia el final del fallo hay una breve mención a la imposibilidad de "tarifar el dolor" que para Nilda Emma Eloy habría implicado "limpiar restos humanos -cráneos y huesos-", no se observa una referencia a lo repugnante que pudo haber sido para ella haber sido sometida a esa labor, aspecto que da cuenta acabada de los límites éticos y jurídicos trasgredidos por los perpetradores, en clara violación de sus derechos humanos.

Su relato nos dice que fue reducida a la calidad de objeto en el trato que le dispensaron como ser humano, que su dignidad se vio menoscabada al acceder a encuentros sexuales a cambio de agua o aire fresco, o a diseccionar restos humanos a cambio de un poco de sol, circunstancias que resultan entendibles, aunque no aceptables, en virtud de las circunstancias de superviviente en la que desgraciadamente se encontraba.

Los sistemáticos tormentos recibidos por Nilda Emma, los traslados de un centro clandestino de detención hacia otro y las constantes violaciones a su integridad física, sexual, mental y espiritual, que tanto ella como tantas otras personas recibieron mientras fueron privadas de su libertad, se ven agravadas porque los delitos fueron perpetrados por funcionarios del estado, cuya misión y deber era velar por la seguridad de los ciudadanos, habiendo por el contrario violado todas las garantías constitucionales.

Aunque en general, la descripción de los hechos probados por los jueces es más bien cruda, con mínimas referencias a emociones morales o sensaciones expresadas por parte de las víctimas y testigos; cabe mencionarse que del relato de Nora Alicia Úngaro los jueces captaron su temor a la muerte, el pánico que implicaba para ella cada traslado a otro centro de detención y el temblor incontrolable que sentía en su cuerpo ante la pérdida de dominio sobre su vida. $\mathrm{Y}$, éste es un punto sumamente relevante para una rica valoración sobre la vulneración del principio de autonomía personal que podría haberse realizado, puesto que situaciones extremas de terror, como las que padecieron las víctimas y testigos de la causa, pueden explicar cómo se lesionan aspectos humanos que hacen a la integridad del ser. 
Por otra parte, Nora refirió que aunque ambas estaban vendadas, pudo percibir que Nilda Emma Eloy se sentía "apesadumbrada" por las lesiones que habían recibido sus padres y su mascota el día de su secuestro. Aunque esto último no fue objeto de valoración, sin dudas da cuenta de la mezcla de un enojo, nostalgia y hasta sentimiento de culpa que pudo haber sentido Nilda Emma. Enojo respecto de sus secuestradores por haber agredido físicamente a personas y animales de su afecto personal, implicando ello un daño adicional al que en persona tuvo que sufrir. Culpa por haber sentido que ella fue el motivo por el cual extrañas personas violaron la intimidad familiar, agredieron a todas las personas que se encontraban presente y ocasionaron daños materiales en su íntimo lugar de reunión, descanso y esparcimiento. La nostalgia, por otra parte se presenta en ambas emociones, puesto que es el dolor presente de un sufrimiento pasado.

Un aspecto más que esclarecedor en el relato de la testigo que vengo comentando es su afirmación en relación a los ultrajes que sufrieron todas las mujeres, por el solo hecho de ser mujeres, así dijo y fue trascripto en la sentencia: "por el hecho de ser mujer todas fueron manoseadas y violadas $y$ esa era la verdad". Sin dudas se trata de un relato sumamente valioso por su coraje y deseo de expresar su "verdad", de compartir el dolor que seguramente habrá significado para ella humillarse y ver como otras se humillaban, sin perjuicio que pareciera gritar a todas voces: "las mujeres fuimos más maltratadas que los hombres". Como ya he dicho, la justicia no dejó expresado por escrito la discriminación en el trato de las mujeres en relación con los hombres, que al igual que "ellas" se encontraban privados de la libertad.

En las emociones expresadas por Nora: en su sentimiento de miedo y en la pesadumbre percibida en Nilda, nos encontramos ante emociones morales densas en contenido cognitivo y valorativo que ayudan a explicar los hechos, y a formar una visión completa sobre los derechos humanos lesionados.

De la descripción de muchos relatos recogidos en la sentencia en relación con los crímenes cometidos contra Nilda Emma Eloy surge la crueldad en el trato recibida por las víctimas, siempre vendadas, con sus manos y pies 
atados y sometidos a interminables sesiones de tortura, en algunos casos sometidos a interrogatorios "incoherentes", afirmaron los testigos. Atilio Gustavo Calotti manifestó que recibió descargas eléctricas en sus genitales, que sólo imaginarse ${ }^{214}$ una nueva tortura era "insoportable" y que dicha experiencia era algo que: " uno no puede relatar y transmitir... el mundo se... cae encima y el dolor es insoportable". Los constantes ataques a la integridad sexual como método de tortura, claramente violatorio de los derechos humanos, también pueden ser interpretados como un deseo de atrofiar el placer en otro ser humano; es una forma de degradación en la que el sólo hecho de causarla podría ocasionar sádico placer a quien la lleva a cabo. En términos legales, llevar a cabo tormentos de todo tipo, con o sin orden de mando militar, implica una responsabilidad por la degradación humana ocasionada y por la ausencia de conciencia del valor del derecho a la vida.

Jorge Julio López fue secuestrado de la puerta de su domicilio, ubicado en el barrio "Los Hornos" de la localidad de La Plata, provincia de Buenos Aires, el 27 de octubre de 1976 en un operativo que dirigió Etchecolatz, que incluyó cerca de cien personas. Le vendaron los ojos con su pulóver, lo introdujeron en un vehículo y lo condujeron hasta una chacra en las cercanías del aeropuerto de La Plata, que reconoció por el olor de los "cerdos"; pudiendo escuchar a Etchecolatz cuando felicitó a sus subordinados por haber "agarrado a estos dos montoneros", en alusión a Rodas, otro hombre que ya se encontraba detenido dentro del vehículo cuando él ingresó.

Su declaración está repleta de relatos sobre los golpes y torturas con "picana eléctrica" que padeció, y de testimonios de haber visto y oído gritos de otras personas torturadas que reconoció en su paso por distintos centros clandestinos de detención. Expresó haber sido adormecido con albóndigas, junto con otras tantas personas detenidas, oportunidad en la que fueron cargados en un camión y trasladados. Narró que recibían como remedios orín y que en una ocasión, al solicitar un medicamento para la sarna, le apalearon la cabeza dejándole una marca blanca que nunca se le fue. Recordó haber

\footnotetext{
214 Podemos constatar aquí el rol que juega la imaginación dentro del estado emocional de la víctima. La imaginación de lo que iría a suceder, basándose en lo efectivamente padecido, cargaba la emoción de ansiedad y angustia concomitantemente.
} 
estado en el centro de detención de Arana y luego haber sido trasladado a la Comisaría Octava de La Plata, sitio en el que al verlos, a él y otros detenidos, le habrían referido al chofer que los llevó hasta allí: “¿de dónde los trajeron, del cementerio?" ya que por su aspecto de espectros daban "asco". En dicho lugar fue reconocido por un Oficial de policía, vecino de su hermana y, recién ahí, después de tres meses, pudo asearse, cortarse el pelo y la barba y descansar por turnos en un colchón, recuperando su libertad el 4 de abril de 1977.

Resulta notable que las autoridades judiciales hayan resaltado del relato de López, que "Etchecolatz no tenía compasión", que fue él quien dirigió la matanza y en persona los "pateaba". ${ }^{215}$ Merece destacarse, además, que los jueces hayan dejado constancia en el acto judicial que el testimonio brindado por López -respecto de las torturas recibidas por Patricia Dell'Orto y Ambrosio Francisco De Marco, otras víctimas de esta causa- estaba recargado de "congoja", siendo por ello que: "durante el trascurso de su declaración en el juicio, el recuerdo de los hechos le produjo un estado de angustia que al ser percibido por el tribunal motivó su atención por parte del médico de la Municipalidad, quien se encontraba a ese efecto en la sala contigua a la audiencia”.

Es así como quedó reflejado en la sentencia que López fue testigo ocular del fusilamiento de Patricia y Ambrosio, mediante el disparo de un arma que impactó con una bala en sus cabezas y que también: "vio cuando torturaban a Patricia Dell'Orto pero aclaró que no deseaba decirlo delante de la familia porque le "daba lástima"' y que, por su parte, Alfonso Mario Dell'Orto, el padre de Patricia, manifestó que tras intensas búsquedas de su hija y su yerno, en las que las autoridades del Ministerio del Interior "se burlaran de uno", fue recién con el testimonio de López que pudo constatar que todo: "se trató de una burla cruel y trágica y de desprecio por la verdad que sufrieron buscando saber algo".

\footnotetext{
215 Todas las declaraciones del juicio se encuentran filmadas y documentadas por el Museo de Arte y Memoria, de la Comisión Provincial por la Memoria, en el que se puede conseguir el documental cinematográfico "Un Claro día Justicia", dirigida por Ana Cacopardo e Ingrid Jaschek y producida por Mariana Martínez Alcántara, que narra los sucesos acontecidos en torno al proceso y condena de Etchecolatz, así como las campañas intimidatorias y amenazantes que sufrieron las víctimas, testigos y jueces de la causa. Véase: http://www.comisionporlamemoria.org/museodearteymemoria/inicio.php
} 
La ausencia de compasión en el perpetrador percibida por López y la lástima que luego sintió en los estrados de narrar hechos cruentos delante de los progenitores de Patricia fueron percibidas y resaltadas por los jueces, aunque no fueron evaluadas en términos cognitivo-evaluativos. Me ocuparé de analizar ambas.

La crueldad es una emoción varias veces mencionada por los jueces respecto de las acciones llevadas a cabo por Etchecolatz, a quien también calificaron como persona "cruel". Se trata de una emoción moral clave, en términos de respeto por los derechos humanos, puesto que quien es cruel establece una distancia respecto de sus congéneres que traspasa los límites de la frialdad en los vínculos ya que, atentando contra la vida e integridad física, psíquica, emocional y espiritual de otros seres humanos, se olvida que forma parte de la misma especie e ignora la igualdad ética que lo une a sus víctimas. La crueldad atroz, en crímenes repugnantes como los que tuvieron que juzgarse en este caso, en que la distinción se fundó en las condiciones políticas de las personas, pone sobre el tapete las afrentas al principio de igual valor y dignidad humana y la consecuente vulneración de derechos humanos por parte de las autoridades estatales.

La angustia sentida por la víctima, calificada por las autoridades judiciales como "congoja", da cuenta de un doloroso enojo reminiscente ${ }^{216}$ en la persona de la víctima, de una honda herida que se abría en su interior con sólo recordar las torturas y malos tratos recibidos, así como de la imaginación ${ }^{217}$ acerca de lo que aquellos progenitores pudieran llegar a sentir, al enterarse de los ultrajes a los que había sido sometida su hija.

Esta emoción moral también es digna de consideración en la justicia en torno al respeto de los derechos humanos, puesto que revela el intenso dolor que para un testigo ocular significó presenciar hechos atroces, en los que otras víctimas resultaron muertas, implicando su sentimiento de lástima una

\footnotetext{
${ }^{216}$ Conforme con la clasificación de las emociones efectuada por Martha Nussbaum en Upheavals of Thoughts, descripta en la Parte Primera, Sección Primera, aquí podemos enmarcar claramente el cuadro emocional de angustia de la víctima como una emoción situacional, dado que se reporta en el momento presente pero yace en un contexto histórico que la genera.

217 Así, verificamos como la imaginación es un elemento necesario, aunque no constitutivo, de las emociones morales.
} 
capacidad de empatía que el testigo mantenía intacta al momento de declarar, a pesar de todo su padecimiento. En sus testimonios orales puede escuchárselo replicando los tonos de voz e insultos recibidos por Etchecolatz y uno de sus subordinados, así como vérselo gesticulando respecto de las formas en que eran atados y golpeados. Sus expresiones emocionales, su lenguaje simbólico, corren el velo de las huellas traumáticas que quedaron asentadas en su ser, las mismas que obstaculizaban la reiteración de la secuencia de los hechos delante de los padres de Patricia, significando esto que él también resultó víctima de todos los delitos crueles y degradantes que tuvo que presenciar. Sin dudas su testimonio se mantuvo impecable, y lo lamentable es su nueva desaparición.

En el acápite "b" referente al "Debate" de la causa, que se encuentra inserto en el punto tres, denominado "Responsabilidad", los jueces formularon una brevísima apreciación de los principales testimonios y del clima que se vivió en las audiencias.

Al valorar la prueba de cargo contra Etchecolatz, los jueces calificaron de "dramáticos" y "horrorosos" los testimonios de víctimas y testigos, así como el clima que se vivenció en las audiencias; y evaluaron como un "calvario" y un "martirio" el padecimiento que los familiares de las víctimas tuvieron que soportar por los secuestros, desapariciones y eventualmente el reconocimiento de restos humanos. De tal modo, los jueces demostraron fehacientemente un crimen de lesa humanidad que trasciende a las víctimas y lesiona a familiares, amigos y la humanidad en general.

Luego, en el acápite relativo a la "Graduación de la Pena", dentro del punto "La Pena", las autoridades judiciales refirieron que les resultaba imposible tarifar el dolor: "de los tormentos de todo tipo a los que fue sometida Nilda Emma Eloy durante su ilegal cautiverio, ... Tampoco las marcas en el cuerpo y la mente de Jorge Julio López producidas por torturas dirigidas en persona por Etchecolatz, las que sin embargo no le impidieron señalarlo en el debate con la valentía con que lo hizo". De tal modo, los magistrados realzaron el coraje de ambas víctimas y señalan las huellas profundas que zanjaron sus vidas a raíz de las heridas ocasionadas por los delitos horrorosos de los que 
resultaron objeto de limpieza y degradación humana.

En relación al relato y defensa de Etchecolatz, no se observa un punto ni un acápite en todo el fallo que se denomine "defensa" y/o describa todas las intervenciones del actor en su proceso judicial, que exprese si declaró o no, en caso afirmativo qué dijo y en qué consistieron los argumentos y alegatos formulados por sus representantes legales, si es que los hubieran formulado. Sin embargo, se observa en el punto tres, denominado "Responsabilidad", el acápite "c", Ilamado "Descalificación Generalizada", en el que los jueces efectuaron lo que a mi juicio constituye una valoración negativa o refutación de la defensa, sin una ilustración de los argumentos soportados por el enrostrado que, fueron calificadas de infundadas por los magistrados: "Es importante destacar que las imputaciones lanzadas por los letrados no fueron siquiera fundamentadas" y "si bien la mayoría de las afirmaciones transcriptas carecen de fundamentación y en muchos casos de seriedad, caben algunas reflexiones por la magnitud y gravedad de las imputaciones efectuadas". Es decir, se observa en el acto judicial decisorio una valoración de la defensa pero sin una breve y autónoma parte dedicada a la descripción de la misma, que también hace al derecho de defensa.

Las autoridades judiciales calificaron a la defensa de Etchecolatz de "confusa", "agresiva" y "descalificadora" de los testimonios de las víctimas, a quienes literalmente habrían considerado "combatientes y guerreros que pelearon contra quienes defendían las instituciones"; al extremo de solicitar la nulidad de toda la prueba, planteo que fue considerado poco serio, imposible y "temerario" por los jueces.

Las autoridades entendieron, y así quedó plasmado en el acto judicial, que calificar de combatientes y guerreros a testigos y víctimas era una actitud agresiva por parte de la defensa que atentaba no sólo a quienes se estaba atacando sino que: "al sistema todo".

Resulta interesante y muy valioso remarcar que los jueces pudieron observar en las audiencias y reflejar en la sentencia una grosera "burla" por parte de la defensa respecto del dolor que habrían padecido las víctimas, 
consistente en expresiones tales como: "¿si estaban vendados cómo pudieron verlo?", en alusión a Etchecolatz o, más brutal aún: "muchos que dijeron que desaparecieron y luego fueron encontrados muertos, fueron muertos por los mismos compañeros, las hordas", expresión irónica que alude a salvajismo.

La presencia de expresiones burla o de humor grotesco humillante son significativas, porque implican un menosprecio respecto de otro ser humano, a quien se lo considera "inferior", "animal" o degradado; aspecto relevante para mostrar que la falta de respeto por la dignidad humana existió y persistió hasta el momento en que el perpetrador y sus letrados patrocinantes estuvieron presentes en los estrados judiciales. En la sentencia se podrían haber expresado, como un refuerzo a la tesis de la violación continuada de derechos humanos, además del secuestro, la desaparición y las torturas. Puesto que el objeto de burla era histórico y se extendía en el tiempo por los mismos motivos, razón más que relevante para inferir poca capacidad de autocrítica por parte del perpetrador; además de insensibilidad ante el derecho la vida e irresponsabilidad por los crímenes atroces cometidos.

Otro punto para resaltar de la sentencia, es la objeción que las autoridades judiciales formularon en torno a la apelación al resentimiento de las víctimas y la querella, advirtiéndose como una estrategia de la defensa, para desvirtuar hechos o provocar mayor dolor en las audiencias, esto dijeron los jueces al respecto: "Descalificaron a las querellas por tener resentimiento", señalando que "por eso no debieron haber sido tomadas, sobre todo las que representan a derechos humanos que se han adueñado del mundo"' y refutaron esta solicitud de exclusión y descalificación de las querellas refiriendo que la intervención de las organizaciones de derechos humanos en los procesos judiciales está reconocida constitucionalmente y además "enaltece" los estrados judiciales.

Por otra parte, de las constancias obrantes en la sentencia se infiere que la estrategia de la defensa consistió en asociar el resentimiento con un deseo de venganza que era, bajo su perspectiva, asumido por las autoridades del gobierno nacional electo al momento del juicio; así quedó plasmado: "los continuadores de los montoneros ahora en el poder continúan con su venganza 
ahora diferida". Claramente puede observarse en estas frases de la defensa, la agresividad con que se atacaron los testimonios de cargo, sin siquiera dar una razón de los hechos controvertidos que avale una posición sólida. Es notable la apelación al resentimiento por parte de la defensa, puesto que más allá de lo que cada ser humano sobreviviente perjudicado por las persecuciones, secuestros y desapariciones haya humanamente podido elaborar en torno al dolor, es obvio que se trata de hechos que, al no haber sido esclarecidos en tiempo y forma, han persistido y resentido no sólo a las víctimas sino que a la sociedad en su conjunto; razón por la que la apelación al dolor resentido de las víctimas por parte de la defensa podría haber sido valorada, además de calificada como burla, como una obtusa negación de los hechos en detrimento de la verdad en la justicia. En tal sentido se podría decir que la defensa fue coherente al negar también: la legitimidad y aplicabilidad de muchos tratados de derechos humanos; la existencia de 498 centros clandestinos de detención en la Argentina durante la última dictadura militar; la competencia del Poder Judicial de la Nación para intervenir en su juzgamiento, alegando que debió haber sido juzgado por el Consejo Supremo de las Fuerzas Armadas Argentinas; y la aplicación de la regla de la sana crítica o criterio de libres convicciones que las autoridades judiciales tienen para valorar las pruebas, solicitando se declare su inconstitucionalidad, planteo que fue valorado por los jueces como "irracional" y contrario al sistema de protección de los derechos humanos.

Una última consideración sobre esta negación rotunda del victimario tanto en relación a los hechos como al derecho aplicable y autoridades competentes para intervenir- es que la misma obstaculiza de algún modo sutil la reconciliación pacífica en la sociedad, puesto que no se vislumbra ni un mínimo reconocimiento ni arrepentimiento de su parte, al menos en público.

En resumen, todo lo observado sobre la consideración de las emociones morales en el acto judicial en cuestión me permite afirmar que si bien las autoridades efectuaron valoraciones genéricas respecto de las emociones expresadas por víctimas y testigos, profundizaron bastante más la valoración de la defensa, aunque siempre en términos negativos formulando objeciones y refutaciones. Dejaron sin embargo plasmado en la sentencia que se trató de 
una causa cuya dimensión dramática puede comprenderse a través de los valiosos relatos de víctimas y testigos. Rescataron emociones morales importantes, como la burla expresada en las audiencias por la defensa; la crueldad del perpetrador; la congoja en una de las víctimas; el temor traducido en pánico y terror sentido por víctimas y testigos; el dolor profundo de los familiares; el desprecio y degradación humana y el resentimiento y deseo de venganza apelado estratégicamente por la defensa en relación con las víctimas y la querella.

Podría decirse que si bien dichas emociones morales no fueron evaluadas teniendo en cuenta su contenido cognitivo y evaluativo, fueron percibidas y captadas por las autoridades judiciales. Las emociones que sí fueron consideradas contribuyeron de manera significativa a que en el acto de justicia decisorio se reflejara un estado de mayor veracidad de los hechos narrados y del clima judicial vivenciado.

Valorar aspectos emocionales humanos en la justicia al mismo tiempo que se valoran argumentos legales, coadyuva al progresivo respeto por los derechos humanos de todos los actores de un juicio: partes y testigos.

En el punto que sigue, analizaré las emociones morales manifestadas por los jueces de la causa en el acto de justicia decisorio. Teniendo en cuenta el respeto por los derechos humanos, trataré de elucidar si las emociones vertidas en el juicio respecto de los hechos y la persona condenada, afectaron al principio de imparcialidad ética en la justicia o implicaron una intrusión en la moralidad ajena, como objetan varios autores.

\section{Sentimientos morales de los jueces en el veredicto}

En el acto de justicia decisorio de la condena impuesta a Etchecolatz, al ponderar algún posible factor atenuante de la pena establecida, los jueces de la causa dejaron sentado su sentimiento moral de "repugnancia" ante los crímenes juzgados. El texto en cuestión, como ya anticipamos, dice así:

"No habiendo atenuante de ninguna especie para las conductas llevadas a cabo por Etchecolatz, se impone aplicar el máximo de la pena prevista por nuestra legislación dado que cualquier otra opción 


\section{resultaría repugnante a nuestras convicciones".}

Según ya hemos visto, la repugnancia es una emoción moral controversial en términos jurídicos. ${ }^{218}$ Hay quienes piensan que tiende a jerarquizar negativamente su objeto formal de conocimiento, a infravalorarlo, propiciando su inminente extirpación o exterminio, atentando ello contra los principios éticos de igual valor y dignidad humana, autonomía personal y respeto por la diversidad cultural. Por lo tanto, para algunos autores como Nussbaum resulta impropia como conductora de normas jurídicas respetuosas de los derechos humanos y, en consecuencia, es muy peligrosa su calificación dentro de una sentencia judicial. ${ }^{219}$ Pero también hay quienes la reivindican para el derecho en lo criminal por cuanto se opone con potencia a la crueldad y marca un compromiso ético serio con la punición de crímenes atroces contra la humanidad, siempre que se respeten las normas internacionales de protección de los derechos humanos. ${ }^{220}$ En este contexto dicotómico que presenta la repugnancia, pasaré a analizar el párrafo precedentemente citado.

Los jueces establecieron que no encontraban ningún factor que indique que la pena impuesta a Etchecolatz podía ser atenuada. Calificaron los actos llevados a cabo por el agresor como "aberrantes", y calificaron al agresor en relación con dichos actos como un ser "cruel". Obviamente que tales apreciaciones fueron transmitidas en la sentencia como producto de los hechos narrados por las víctimas y los testigos dentro del proceso judicial que los jueces conocieron.

Hacia el final del fallo, al analizar la responsabilidad de Etchecolatz por la comisión de crímenes de lesa humanidad, los magistrados sostuvieron que banalizar los actos atroces que cometió o justificar las degradaciones humanas padecidas por las víctimas implicaría un "acto de brutalidad insoportable". Los

\footnotetext{
${ }^{218}$ Recordemos que William Ian Miller se refiere a la repugnancia como una emoción cuyo efecto es paradojal puesto que puede ser útil para censurar hechos atroces pero a la vez perniciosa en cuanto a la calificación intrínseca de lo que resulta repugnante.

${ }^{219}$ Esta es la postura que Martha Nussbaum adopta en El Ocultamiento de lo Humano. Repugnancia, Vergüenza y Ley, en relación a la construcción de estándares normativos conducidos por la repugnancia. Concuerdo con ella, y estimo que su inclusión en normas jurídicas resulta problemática e incompatible con el respeto de derechos humanos. Me refiero a normas en un sentido amplio, abarcadoras de leyes, decretos, resoluciones y políticas públicas.

${ }^{220}$ Esta es la posición de Dan Kahan, que comparto y amplío en relación con el respeto de los derechos humanos y la punción de crímenes de lesa humanidad.
} 
calificativos de atroces y brutales remiten, por cierto, a emociones compatibles con la repugnancia o el asco moral.

Recordemos también que para efectuar las valoraciones de las pruebas los jueces aplicaron el criterio de las libres convicciones que éticamente corresponde a la actividad de los magistrados. ¿Podría cuestionarse que dicha valoración es una intromisión a la moralidad ajena, que vulnera el principio de autonomía personal? Estimo que se trata de una valoración efectuada dentro de la esfera de conciencia de las autoridades judiciales y en función con la ética que su actividad les impone. Al decir que otra opción repugna a sus convicciones los jueces de la causa no están juzgándolo por sus cualidades intrínsecas, por fuera de los actos por los que ha sido procesado, sino que están diciendo que el límite que se ha trasgredido, por todos los fundamentos brindados que lo acreditan como criminal contra la humanidad, es tan grosero que merece la más severa sanción penal.

De este modo se observa que más allá de la condena legal impuesta y sin perder imparcialidad, los jueces fueron empáticos con el dolor de víctimas y testigos, y formularon una condena moral contra Etchecolatz, porque otra opción hubiera sido repugnante a sus convicciones. Justificar las atrocidades perpetradas hubiera sido insoportable en su conciencia como jueces y seres humanos sensibles que forman parte de una sociedad democrática, pluralista e inclusiva en búsqueda de la verdad histórica.

En su libro Juicio al Mal Absoluto (1996), Carlos Nino analizó la justificación de penas a aquellas personas que vulneraron normas de protección de los derechos humanos masiva y sistemáticamente, aquellas que han realizado actos criminales que, como decía Arendt, nos resulta difícil o imposible perdonar. ${ }^{221}$ También Jaime Malamud Gotti se ocupó del tema, y en este caso y como vimos antes, en relación con las emociones morales y la dignidad humana lesionada. ${ }^{222}$ Ambos autores difieren en cuanto a las consecuencias que tuvo el juicio a las Juntas Militares, porque mientras Nino pensaba que había contribuido a pacificar a la comunidad porque si no se

\footnotetext{
${ }^{221}$ Nino, Carlos S., (1996), Juicio al mal absoluto, Buenos Aires: Ariel, 2da. Ed., 2006.

222 Malamud Gotti, J., "Dignidad, venganza y democracia”, obra citada.
} 
enjuiciaba y sancionaba penalmente a los responsables de las violaciones a los derechos humanos la gente recurriría a la venganza; Malamud piensa lo contrario. Malamud cree poder demostrar empíricamente que el juicio a las Juntas Militares no contribuyó a pacificar la comunidad sino que la fraccionó, y estigmatizó a un grupo de personas: a los miembros de las fuerzas de seguridad del estado, sin llegar a juzgar y sancionar a los civiles que colaboraron con ellos, y de este modo, argumenta el autor que lejos de permitir la reconciliación alentó el resentimiento.

Como ya he revisado al inicio de esta investigación, Malamud propuso una justificación de juicios y penas basada en las emociones moralmente relevantes de las víctimas, o sea de quienes sufren, como una razón independiente para condenar la violación de derechos humanos; lo que denominó "retribucionismo de fines". ${ }^{223}$ En este sentido, su tesis es valiosa porque separándose de utilitaristas y de retribucionistas tradicionales, Malamud plantea conferirle preponderancia a la reparación del daño emocional que la lesión hubiera causado. Concuerdo en este punto con el autor porque la restauración de la dignidad humana menoscabada es un aspecto de vital importancia en la justicia como punto de partida para el reconocimiento de derechos humanos vulnerados, pero su teoría sigue basándose en la devolución y pasa de centrarse en el acto causado o hecho criminal, como comunmente lo hacen los retribucionistas tradicionales, a centrarse en el acto padecido o daño.

En la sentencia judicial del caso bajo análisis, las autoridades judiciales efectivamente se centraron en el padecimiento de las víctimas, expresado por ellas mismas y por los testigos, e intentaron con el fallo reivindicar su dignidad lesionada. El lenguaje utilizado por los jueces parece contribuir a ello. Recordemos, además, que la repugnancia que los jueces expresaron no se refería a la persona del victimario, ni tan siquiera a sus actos, sino a un estado de conciencia sobre las posibles lesiones a las víctimas y a la humanidad en su conjunto, que ocasionarían en caso de aplicar una pena menor.

Pero, reitero aquí que pensar en términos de respeto por los derechos 223 Malamud Gotti, J., obra citada, pp. 142 y ss. 
humanos implica reflexionar y considerar a todos los seres humanos comprometidos en el asunto judicial: personas víctimas y victimarias, testigos, e incluso la sociedad, como víctima indirecta de las lesiones producidas a individuos en particular. Es por ello, que una teoría de justicia que sólo se centre en las emociones relevantes de las víctimas y no atienda a las emociones relevantes de las personas ofensoras o que desoiga los sentimientos de la sociedad en torno a los hechos investigados resultará facciosa o al menos cuestionable, puesto que para que haya restauración de la dignidad humana y corrección de actitudes lesivas es preciso el dialogo sincero y la expresión y consideración de razones y emociones de todas las partes: la restauración judicial ha de ser integral.

Por otro lado, Malamud argumenta que el proceso de "inculpación" de los personas responsables de las violaciones a los derechos humanos excluyó a la población civil que colaboró con el gobierno de facto, que esas mismas personas luego se convirtieron en acusadoras, que finalmente los miembros de las Juntas Militares se sintieron presos de una venganza generalizada: de "vindictia colectiva" y que ese sentimiento generó un resentimiento que impidió la reconciliación necesaria para la democracia. Recordemos que este fue también el argumento central de la defensa de Etchecolatz esgrimido en el juicio, que ya he analizado en su contexto.

Acierta el autor al considerar que una parte de la sociedad primordialmente quienes tuvieron el poder económico para hacerlo y quienes querían imponer el modelo económico liberal que exitosamente pusieron en marcha los golpistas- quedó fuera de los juicios, resultó impune e incluso cambió de piel y quiso mostrarse como demócrata de la primera hora, sin embargo disiento con su análisis sobre el resentimiento como argumento del fracaso de una reconciliación pacífica.

¿Qué pruebas hay que demuestren que fue ésa la causa por la cual los agentes de seguridad del estado no reconocieron su responsabilidad, pidieron perdón o intentaron algún tipo de arrepentimiento público?, ¿hubiera sido mejor no juzgarlos para evitar el resentimiento?, y ¿por qué será que los argentinos no nos arrepentimos ni podemos aún perdonar? 
Como ya lo he analizado en profundidad al revisar las pasiones vindicativas y su relación con un esquema de punición retributivo en la justicia, la tendencia de asociación directa de algunas emociones reactivas como la indignación, la ira, la revancha o el deseo de venganza con el resentimiento es muy discutida en la literatura. Peter Strawson, por ejemplo, en "Libertad y Resentimiento" (1974), refiere que las actitudes reactivas individuales y sociales:

“...descansan sobre, y reflejan, una expectativa y una demanda de manifestación de un cierto grado de buena voluntad y compromiso por parte de los demás seres humanos hacia nosotros mismos; o cuando menos, descansan sobre la expectativa y la demanda de que no se manifestará mala voluntad activa ni desinterés o indiferencia... no simplemente hacia uno mismo, sino... hacia todos los hombres". 224

Obviamente la defensa de Etchecolatz atinó al esgrimir una actitud reactiva por parte de las víctimas y de la querella, pero nunca podríamos afirmar que ello generó un resentimiento en el condenado Etchecolatz que le hubiera impedido comprometerse y reconocer los hechos que se le endilgaban, arrepentirse, pedir públicamente perdón por los daños infinitamente causados e intentar, de ese modo, cerrar las heridas que claramente podía ver en sus víctimas. La tesis del resentimiento resulta inaceptable en este caso. Los derechos humanos de Etchecolatz fueron garantizados por la justicia durante todo el proceso judicial, más allá de las expresiones populares reactivas que se sostuvieron, en parte por su reticencia y negación a colaborar con la verdad histórica.

Para decirlo junto con Strawson, si bien es cierto que la indignación y la desaprobación moral tienden a inhibir o limitar nuestra "buena voluntad" hacia la persona ofensora objeto de tales actitudes al menos parcial o temporalmente; sin embargo tales actitudes también pueden ser interpretadas en términos de una demanda moral cuando se han cometido hechos aberrantes. Bajo esta luz podría también interpretarse el uso de un lenguaje emocional reactivo por parte de la sociedad, de las víctimas y de los jueces en el caso judicial examinado. Siempre que esas actitudes reactivas respeten la agencia moral de los ofensores, su dignidad humana, como fue el caso en la

224 Peter F. Strawson, (1974), Libertad y Resentimiento y otros ensayos, traducción de Juan José Acero, Barcelona: Paidós Ibérica, 1995, pp. 37-67. 
Argentina, la indignación o incluso la repugnancia ante hechos aberrantes también puede ser una forma de manifestar la importancia que reviste para esos actores que la comunidad moral sea preservada, restaurándose la dignidad humana de quienes sufrieron los actos atroces penosamente. 


\section{Conclusiones: Emociones, Justicia y Derechos Humanos}

Inicié esta investigación indagando sobre el conocimiento de las emociones en los seres humanos y el punto de vista moral que aportan respecto de lo que para cada quien resulta vital en su propio esquema de valores y metas. Mi punto de partida fue sostener que todos los conflictos llevados a la justicia poseen un contenido emocional irreductible y que como seres humanos dotados de razón y emoción, dicho aspecto emocional no debiera ser apartado del juicio al momento de sentenciar sobre derechos humanos lesionados.

Es por ello que intenté mostrar, siguiendo parcialmente la teoría de Martha Nussbaum, que las emociones pertenecen a la "razón pública", porque son un modo de deliberar sobre asuntos de importancia institucional -como la ira lo es sobre el daño, por ejemplo-, y que algunas emociones como la ira, la compasión y el miedo son esenciales para el derecho, puesto que constituyen razones públicas que contribuyen a proteger a los seres humanos de la vulnerabilidad inherente mediante la construcción de normas jurídicas.

Me propuse explorar ciertas emociones vindicativas como el odio, la ira, la venganza, la revancha, el resentimiento y la repugnancia porque suelen asociarse a un modo de punición retributiva que resulta incompatible con el respeto de los derechos humanos. Dicho estudio me permitió concluir que cuando se tengan en cuenta en la justicia las emociones morales expresadas por las partes y testigos, tales emociones contribuirán a no hablar de más de "castigo" sino de atribución de responsabilidad, sin aumentar el dolor a las personas, víctimas o victimarias; y también contribuirán a reconocer igual valor y dignidad en ambas, a restaurar el sufrimiento de unas y a expandir la consciencia social sobre lo realizado 


\section{en otras.}

En tal sentido sostuve que es posible sortear la aparente tensión entre emociones vindicativas asociadas a un esquema de punción retributivo en la justicia y el respeto por los derechos humanos, mediante la inclusión de una teoría normativa sobre las emociones morales en la justicia que se encuentre en diálogo con los principios éticos de igual valor y dignidad humana, autonomía personal y respeto por la diversidad cultural.

Esto me llevó a revisar la teoría neo estoica de las emociones morales desarrollada por Nussbaum, puesto que al considerar que las emociones interactúan con los pensamientos, "sacudiéndolos", permiten captar aspectos morales relevantes del ser humano que dan cuenta de sus apreciaciones y creencias. Dichos elementos cognitivos y evaluativos, según Nussbaum, no deberían ser neutralizados o suprimidos, como proponían los filósofos de la escuela helenista, sino ponderados como áreas de vulnerabilidad humana que el derecho y la justicia debería proteger.

Puesto que algunas emociones morales como la humillación, la repugnancia y la vergüenza son "jerarquizantes", y tienen una conexión directa con la privación de la libertad en algunos casos de conductas que no causan daños a terceros, debatí la pertinencia de su consideración en la justicia en función del respeto de los principios éticos en que se fundan los derechos humanos dado que, como considera acertadamente Nussbaum, quienes aprecien los valores democráticos centrales de libertad individual e igualdad ética deberían desconfiar profundamente del uso de esas emociones en el derecho y en las políticas públicas.

Repasé la posición de Nussbaum, consistente en objetar la reivindicación de la repugnancia en el derecho criminal puesto que, según la autora, quien la formula no haría una distinción clara entre un acto moralmente repugnante y la persona que lo comete, y por esa misma razón la repugnancia tendría un impacto directo sobre el valor intrínseco que le asignamos a las personas. Examiné su argumento central, que postula que al calificar a una persona ofensora como repugnante lesionamos su dignidad y por lo tanto no la 
consideramos un ser humano. Nussbaum sostiene que al pensar que quien cometió un acto aberrante es un "monstruo", tendemos a colocarlo fuera de los límites de nuestro propio universo moral y a no tomar consciencia de "la presencia del mal en nosotros mismos".

A diferencia de Nussbaum y junto con Salles sostuve que la idea de dignidad humana suele ser empleada en los discursos en forma ambigua y objeté el argumento de Nussbaum que se basa en tal concepto para excluir la repugnancia de la esfera pública, por entender que no aclara suficientemente cuál es su alcance. Intenté aportar claridad en relación con la noción de dignidad humana y la interpreté, en un sentido kantiano, como el límite ético que se impone en las relaciones interpersonales para reconocer en otro ser humano su capacidad prestar, o no, consentimiento con el modo de trato que se le dispensa; y proyecté esta concepción de dignidad dentro del marco de una sociedad democrática, pluralista e inclusiva en la que sus miembros acordaron proteger su dignidad mediante el establecimiento de normas coercitivas que sancionen a quien la autoridad judicial competente adjudique responsabilidad por lesionar derechos humanos.

Por otro lado, junto con la perspectiva de autores como Dan Kahan, sostuve que la repugnancia es la emoción moral que expresa mayor oposición a las graves violaciones a los derechos humanos, por ejemplo ante los crímenes de guerra, de lesa humanidad, genocidios y femicidios, y que, en tal sentido podría ser considerada incluso como éticamente empática porque ayuda a restaurar la dignidad menoscabada en las personas víctimas de tales crímenes aberrantes y a recuperar un sentido de confianza en los familiares de las víctimas y en la sociedad toda.

Al examinar la sentencia escogida constaté la presencia de expresión de repugnancia por parte de todos los actores intervinientes en el juicio, incluidos los magistrados. Puede inferir de los relatos plasmados en el texto decisorio y de las propias expresiones de los jueces que un sentimiento de repugnancia imperaba en la sociedad al momento de las violaciones de los derechos humanos investigados. En tal sentido, intenté aclarar que una idea de contaminación social promovió la persecución, tortura, desaparición y 
exterminio de personas con adscripción ideológica distinta a la del gobierno de facto que como es de público conocimiento estableció un plan sistemático de exterminio a lo largo de todo el territorio argentino contra todo grupo político, social o religioso que se opusiera al "nuevo orden" que se pretendía instaurar. Dicha práctica de policía llevada a cabo por agentes de seguridad del estado, me permitió argumentar que los crímenes de lesa humanidad en cuestión fueron cometidos en el marco de una "limpieza ideológica" y que esta idea de limpieza podría verse como la antítesis de la "suciedad" que causa asco o repugnancia. Por otra parte, verifiqué la expresión de emociones morales como terror, temor, angustia, asco, vergüenza, pesadumbre, pena y compasión en el relato de víctimas y testigos; emociones que si bien fueron descriptas por los magistrados no fueron analizadas teniendo en cuenta su contenido cognitivo y evaluativo y su relación estrecha con las violaciones a los derechos humanos efectivamente comprobadas; aunque resalté que con relación al victimario, fueron estudiados las expresiones de burla y los constantes alegatos de resentimiento respecto de las víctimas y de la querella. Me detuve brevemente a analizar el resentimiento y su relación con actitudes emocionales reactivas, como la ira y la indignación; e intenté mostrar junto con la posición de Strawson que no necesariamente apelar al resentimiento de las víctimas le impide a la persona ofensora expresar su arrepentimiento y pedir perdón por los daños de toda índole ocasionados, ya que la única forma de disolver el pasado y afrontar el presente es asumiendo un compromiso ético sincero con toda la sociedad.

Luego del análisis de la sentencia concluí que la persona victimaria del caso examinado, que fue procesada por crímenes de lesa humanidad cometidos durante la última dictadura militar en Argentina, tuvo derecho a un debido juicio, a una legítima defensa y también a la posibilidad de participar expresando sus argumentos racionales y emocionales cabalmente y que ellos fueran considerados. Ello me permitió afirmar que la esfera pública judicial constituyó una garantía social para el dialogo pacífico y respetuoso entre testigos, víctimas y victimario; y que si no se pudo obtener tal diálogo en este caso, ello se produjo básicamente por la negativa del último a asumir su responsabilidad por los actos atroces cometidos.

Finalmente, examiné la implicancia de expresiones emotivas por parte 
de las autoridades judiciales dentro de los textos de las sentencias condenatorias o absolutorias, en función del respeto por el principio de imparcialidad y de autonomía personal. Me concentré en el caso de expresiones de repugnancia en las sentencias, ya que su inclusión podía ser incompatible con el respeto de los derechos humanos, y resalté que cuando la emoción se pronuncia sobre los actos aberrantes y sin calificar a la persona ofensora de esa misma forma, puede incluso servir como señal de una flagrante violación de los derechos humanos, tal como es el caso de la sentencia condenatoria que analicé.

Para concluir, creo haber contribuido a mostrar que meritar en la justicia nuestras emociones morales al momento de valorar las defensas de personas víctimas y victimarias no colisiona con una concepción liberal del derecho, respetuosa de la libertad individual y diversidad cultural, sino que por el contrario amplía el horizonte de apreciación en torno a los hechos investigados, arrojando mayor claridad y veracidad en el veredicto, sin que ello implique legitimar prácticas ultrajantes sino, por el contrario, permite arribar al conocimiento preciso de la ocurrencia de los hechos y, según sea el caso, a una atenuación o agravamiento razonablemente justificado de la sanción penal. 



\section{Bibliografía}

ANGYAL, A., A Theoretical Model for Personality Studies, en: http://www.panarchy.org/angyal/personality.html

ARENDT, H., (1958), La Condición Humana, traducción de Ramón Gil Novales, Buenos Aires: Paidós, 3ra. Reimpresión, 2007.

ARISTÓTELES, Ética Nicomaquea, Buenos Aires: Colihue, 2007.

_ Retórica, Buenos Aires: Gradfíco, 2007.

COHEN, R. L., (2001), "Provocation of Restorative Justice”, en Social Justice Research, Vol. 14, No. 2, Junio de 2001, pp. 209-232.

DEIGH, J., (1994), "Cognitivism in the Theory of Emotions", Emotions, Values and the Law, Oxford, Oxford University Press, 2008, 17-38.

- (2010), "Concepts of Emotions in Modern Philosophy and Psychology", Oxford Handbook of Philosophy of Emotion, de Peter Goldie, Oxford: Oxford University Press.

DAMASIO, A. R., (1994), El error de Descartes: la emoción, la razón y el cerebro humano, traducción de Joandomènec Ros, Buenos Aires: Paidós, Drakontos Bolsillo, 2010.

DESCARTES, R. (1649), Las Pasiones del Alma, Buenos Aires: Altamira: Retórica, 2007.

FRAZER, J. G., The Golden Bough: A Study in Magic and Religion, republicado por Forgotten Books en 2008. http://books.google.es/books?id=4bT3ACjkRasC\&lpg=PP1\&pg=PP1\#v=onepage\&q\&f=false

FREIBERG, A., (2001), "Affective vs. Effective Justice: Instrumentalism and Emotionalism in Criminal Justice", Punishment and Society, pp. $265-278$.

FREIBERG, A. y CARSON, W. G. (2010), "The Limits to Evidence-Based Policy: Evidence, Emotion and Criminal Justice", The Australian Journal of Public Administration, vol. 69, no. 2, pp. 152-164.

FRIJDA, N. H., (1993), "Lex Talionis: On Vengeance", S. M. Van Goozen, y otros, Emotions: Essays on Emotion Theory, Hillsdale, New Jersey: Lawrence Erlbaum, 1994, pp. 263-290.

GAMBOA TAPIAS, C. (2004), "Perdón y Reconciliación Política: dos medidas restaurativas para enfrentar el pasado", en Revista Estudios Socio-Jurídicos, Universidad del Rosario, Bogotá, Colombia: enero-junio, Vol. 6, No. 1, pp. 81-110.

HUME, D. (1739), Disertación sobre las pasiones y otros ensayos morales, introducción, traducción y notas de José Luis Tasset Carmona, Ed. Bilingüe, Barcelona: Anthropos, 1990.

JAMES, W., (1884), "What is an Emotion?" Mind, Vol. 9, No. 34, pp. 188-205.

KARSTEDT, S., (2002), "Emotions and Criminal Justice", en Sage Publications, London, Thousand Oaks and New Delhi, Vol. 6, No. 3, p. 299-317.

KAHAN, D. M., (1998), “The Anatomy of Disgust in Criminal Law”, Michigan Law Review 96, pp. 1621-1657.

_ (1999), "The Progressive Appropriation of Disgust", S. Bandes (edit.), The Passions of Law, New York: New York University Press, 2001, pp. 63-79.

KANT, I., (1797), Metaphysical Elements of Justice, Part I of the Metaphysics of Morals, $\left(2^{\text {nd }}\right.$. Ed.), introducción, notas y traducción de John Ladd, Cambridge: Hackett Publishing Company, 1999.

KOHEN, A., (2009), "The personal and the political: forgiveness and reconciliation in restorative justice", en Critical Review of International Social and Political Philosophy, Vol. 12, No. 3, pp. 399-423.

KULLASHI, M., (2003), "Limpieza Étnica en la ex-Yugoslavia", traducción de Vilma Penagos, Revista Praxis Filosófica, No. 16, enero-junio, pp. 78-107.

LEUNG, M., "The Origins of Restorative Justice", publicado por el Departamento de Justicia de Canadá en: $\underline{\text { http://cfcj- }}$ fcic.org/clearinghouse/drpapers/leung.htm

MALAMUD GOTI, J., (2000), "Dignidad, Venganza y Democracia" en Revista Jurídica de la Universidad de Palermo, Año 5, No. 1, pp. 135-160.

MASSARO, T. M., (1999), "Show (some) Emotions", S. Bandes (edit.), The Passions of Law, New York: New York University Press, 2001, pp. 80-120. 
MCCOLD, P. Y WATCHEL, T., (2003) "En busca de un paradigma: una teoría sobre justicia restaurativa”, XIII Congreso Mundial de Criminología, International Institute for Restorative Practices, publicada en: www.restorativepractices.org

MILL, J. S., (1861), El Utilitarismo. Un sistema de la lógica (libro VI, capítulo XII), traducción de Esperanza Guisán, Madrid: Alianza, 2007.

(1859), Ensayo sobre la Libertad, traducción de María Ángeles Lavilla Navarro, Madrid: Mestas, Proyectos Anáforas, 2006.

MILLER, W. I., (1997), The Anatomy of Disgust, Cambridge: Harvard University Press.

MURPHY, J. G., (1973), “Marxism and Retribution”, Philosophy and Public Affairs, Vol. 2, pp. 217-243.

_ (1987), “Does Kant have a Theory of Punishment”, Columbia Law Review, Vol. 87, No. 3, pp.509-532.

- (1999), "Moral Epistemology, the Retributive Emotions, and the "Clumsy Moral Philosophy" of Jesus Christ", S. Bandes (edit.), The Passions of Law, New York, New York: University Press, 2001, pp.149-167.

— (2003), Getting even, forgiveness and its limits, Oxford: Oxford University Press.

NINO, C. S., (1980), Los límites de la responsabilidad penal. Una teoría liberal del delito, Buenos Aires: Astrea y Depalma.

_ (1984), Ética y Derechos Humanos. Un ensayo de fundamentación, Buenos Aires: Astrea y Depalma, 2da. Ed., 2007.

— (1996), Juicio al mal absoluto, Buenos Aires: Ariel, 2da. Ed., 2006.

NUSsBAUM, M. C., (1978), Aristotle's Motu Animalium, Princeton: Princeton University Press.

— (1990), "El discernimiento de la percepción: una concepción aristotélica de la racionalidad pública y privada", en El conocimiento del amor. Ensayos sobre filosofía y literatura, traducción de Rocío Orsi Portalo y Juana María Inarejos Ortíz, Madrid: Antonio Machado, 2005, pp. 113-201.

— (1994), La Terapia del Deseo, Teoría y práctica en la Ética Helenística. Traducción de Miguel Candel, Barcelona: Paidós Ibérica, 2003.

— (1995), Justicia Poética. La literatura y la imaginación en la vida pública, traducción de Carlos Gardini, Santiago de Chile: Andrés Bello, 1997.

- (1999), "Secret Sewers of Vice", S. Bandes (edit.), The Passions of Law, New York: New York University Press, 2001, pp. 19-62.

_ (2001), Upheavals of Thought, the intelligence of emotions, Cambridge: Cambridge University Press, 2008.

- (2004), "Emotions as Judgments of Value and Importance", Thinking about Feeling, Contemporary Philosophers on Emotions, de Solomon, Robert (edit.), Oxford: Oxford University Press.

- (2004), El ocultamiento de lo humano: repugnancia, vergüenza y ley. Traducción de Gabriel Zadunaisky. Buenos Aires, Katz, 2006.

— (2006), "Emociones humanas y vida política”, Entrevista a Martha Nussbaum, Reason Review, traducción de María Julia Bertomeu para la revista Sin Permiso: http://www.sinpermiso.info/textos/index.php?id=582

PRINZ, J., (2004), “Emotions Embodied”, Thinking about Feeling, Contemporary Philosophers on Emotions, de Robert Solomon (edit.), Oxford: Oxford University Press.

RAWLS, J., (1971), Teoría de Justicia, traducción de María Dolores González, México: Fondo de Cultura Económica, 2006.

REÑÓN, L. V., (2004), "Entimemas”, en DOXA, Cuadernos de Filosofía del Derecho, No. 27, pp. $283-315$.

RICE, S. K., (2009), "Emotions and terrorism research: A case for a social-psychological agenda" en Journal of Criminal Justice, 37, pp. 248-255.

ROZIN, P., MILLMAN, L. y NEMEROFF, C., (1986), "Operation of the Laws of Sympathetic Magic in Disgust and Other Domains", Journal of Personality and Social Psychology, Vol. 50 No. 4, pp. 703-712.

ROZIN, P. y FALLON, A. E., (1987), “A Perspective on Disgust”, Psychological Review, Vol. 94, No. 1, pp. $23-41$.

ROZIN, P., HAIDT, J. y FINCHER, K., (2009), "From Oral to Moral”, Science, Vol. 323, No. 5918, pp. 1179 - 1180.

SALLES, A., (2010), "Sobre el asco en la moralidad”, Dianoia, LV, 64, p. 40.

SCHABAS, W. A., (2008), "What is Genocide? What are the Gaps in the Convention? How to Prevent Genocide?", Foro Regional sobre Prevención del Genocidio, Ministerio del Exterior de la Nación Argentina, Buenos Aires: http://www.cancilleria.gov.ar/portal/dighu/docs/william schabas.pdf

SCHAYA, L., (1989), El Significado Universal de la Cábala, traducción de Ramón del Campo Zohar, Buenos Aires: Dédalo.

SÉNECA, L. A., Diálogos, introducción, estudio preliminar y notas de Carmen Codoñer, Barcelona: Altaya, 1997.

— De la Ira, traducción directa del latín por Francisco Navarro y Calvo, Alicante: biblioteca virtual Miguel de 
Cervantes, 1999.

SOLOMON, R. C., (1980), “Emotions and Choice”, en Explaining Emotions, de Amelié Oksenberg Rorty, Los Angeles: University California Press, pp. 251-252.

_ (1993), "Sympathy and Vengeance: The Role of the Emotions in Justice", S. M. Van Goozen y otros, Emotions: Essays on Emotion Theory, Hillsdale, New Jersey: Lawrence Erlbaum, 1994, pp. 291-312.

- (1999), "Justice v. Vengeance: On the Law and the Satisfaction of Emotions", S. Bandes (edit.), The Passions of Law, New York: New York University Press, 2001, pp. 123-148.

STRAWSON, P. F., (1974), Libertad y Resentimiento y otros ensayos, traducción de Juan José Acero, Barcelona: Paidós Ibérica, 1995.

ZIPURSKY, B. C., (2008), "Coming Clean on Getting Even: Murphy on Hatred and Criminal Justice", Criminal Justice Ethics, Summer-Fall.

DOCUMENTOS BíBLICOS:

La Biblia, traducción de León Dujovne y Manasés Konstantynowsky, correcciones de Moisés Konstantynowski, Buenos Aires: Sigal, 1982.

Talmud Bavli. Tractate Bava Kamma, Vol. III (folios 83b-119b), elucidado por Rabbi Abba Zvi Naiman y Rabi Mendy Wachsman, Nueva York: ArtScroll Series y The Schottenstein Daf Yomi Edition, 2001.

INFORMACIÓN DOCUMENTAL:

"ESTATUTO DEL TRIBUNAL MILITAR INTERNACIONAL DE NUREMBERG", 6 de octubre de 1945.

"EL CRIMEN DE GENOCIDIO", Asamblea General de las Naciones Unidas, Resolución 96 (I), $55^{\circ}$ período de sesiones, 11 de diciembre de 1946.

"DECLARACIÓN SOBRE LOS PRINCIPIOS FUNDAMENTALES DE JUSTICIA PARA LAS VÍCTIMAS DE DELITOS Y ABUSOS DE PODER", Asamblea General de las Naciones Unidas (AG 40/34), 96º período de sesiones, 29 de noviembre de 1985.

"DECLARACIÓN DE VIENA SOBRE LA DELINCUENCIA Y LA JUSTICIA: FRENTE A LOS RETOS DEL SIGLO XXI", Asamblea General de las Naciones Unidas (A/RES/55/59), 55 período de sesiones, 17 de enero de 2001.

"JUSTICIA RESTAURATIVA", Informe del Secretario General del Consejo Económico y Social de las Naciones Unidas (E/CN.15/2002/5/Add.1), Comisión de Prevención del Delito y Justicia Penal, $11^{\circ}$ período de sesiones, 7 de enero de 2002.

"LA CIDH SE PRONUNCIA FRENTE A LA APROBACIÓN DE LA LEY DE JUSTICIA Y PAZ EN COLOMBIA", comunicado de prensa No. 26/05, Comisión Interamericana de Derechos Humanos, Organización de los Estados Americanos, Washington D. C., 15 de julio de 2005.

"HANDBOOK ON RESTORATIVE JUSTICE PROGRAMMES", Criminal Justice Handbook Series, United Nations Office on Drugs and Crimes, Vienna, 30-31 January 2006, New York: United Nations Publication, E. 06, V. 15.

"COLOMBIA: LA DESMOVILIZACIÓN PARAMILITAR, EN LOS CAMINOS DE LA CORTE PENAL INTERNACIONAL", Informe 481/3, Federación Internacional de Derechos Humanos, octubre de 2007.

\section{JURISPRUDENCIA}

SENTENCIA recaída en la causa nacional No. 13/84.

SENTENCIA recaída en la causa nacional No. 44/86.

SENTENCIA, de Tribunal Internacional para la ex Yugoslavia, dictada en fecha 5 de julio de 2001, en el caso seguido contra Goran Jelisic: http://www.icty.org/sid/7972

SENTENCIA C-979/05, de la Corte Constitucional de Colombia en dictada en Bogotá, Colombia, en fecha 26 de septiembre de 2005, expediente D-5590, caratulado: "Demanda de inconstitucionalidad contra los artículos 78, 192, 327, 330 y 527 de la Ley 906 de 2004 Actor: Rodrigo Paz Mahecha y otros", magistrado ponente: Dr. Jaime Córdoba Tribiño.

SENTENCIA, de la Corte Internacional de Justicia, dictada en fecha 26 de febrero de 2007, en el caso Bosnia y Herzegovina c/ Serbia y Montenegro: http://www.icjcij.org/docket/index.php?sum $=667 \&$ code $=$ bhy $\& \mathrm{p} 1=3 \& \mathrm{p} 2=2 \&$ case $=91 \& \mathrm{k}=\mathrm{f} 4 \& \mathrm{p} 3=5$

\section{NOTAS DE PRENSA:}

PÁGINA/12, 23 de junio de 2006, "EN EL FONDO DE LA DEGRADACIÓN HUMANA. NILDA ELOY RECONOCIÓ A SU TORTURADOR EN LA PANTALLA DE TELEVISIÓN DESPUÉS DE CASI VEINTE AÑOS": http://www.pagina12.com.ar/diario/elpais/1-68904-2006-06-23.html

CLARÍN, 26 de septiembre de 2006, "ES UN HECHO GRAVÍSIMO PARA LA DEMOCRACIA", DIJO EL GOBERNADOR: http://old.clarin.com/diario/2006/09/26/elpais/p-00501.htm

PÁGINA/12, 26 de septiembre de 2006, FELIPE SOLA ATRIBUYO EL SECUESTRO DE LOPEZ A SU DECLARACION JUDICIAL: "ESTO NO ES UNA DESAPARICIÓN CUALQUIERA": http://www.pagina12.com.ar/diario/elpais/173579-2006-09-26.html

LA NACIÓN, 26 de septiembre de 2006, A UNA SEMANA DE LA CONDENA A ETCHECOLATZ SOLÁ DIJO QUE EL 
TESTIGO "ES EL PRIMER DESAPARECIDO EN DEMOCRACIA":

http://www.lanacion.com.ar/nota.asp?nota id $=843594$

PÁGINA/12, 4 de abril de 2007, "EL GENOCIDIO ARGENTINO", por Santiago O’Donnell en: http://www.pagina12.com.ar/diario/elmundo/4-94050-2007-11-04.html

\section{PÁGINAS WEB CITADAS:}

Sitio del Instituto Internacional de Prácticas Restaurativas: www.restorativepractices.org

Sitio del $11^{\circ}$ Congreso para la prevención del Crime n y la Justicia Criminal, llevado a cabo en Bangkok, entre el 18 y el 25 de abril de 2005, que abarcó las siguientes temáticas: tráfico humano, lavado de dinero, corrupción, cibercrimen y Justicia Restaurativa: www.un.org/events/11thcongress/

Sitio del Centro por la Justicia y la construcción de la Paz de la Universidad Menonita del Este, Harrisonburg, Virginia, Estados Unidos: http://emu.edu/blog/restorative-justice/

Sitio en el que se encuentra la carta de la entonces presidenta de Sudáfrica, Phumzile Mlambo-Ngcuka, 17 de noviembre de 2006: http://www.info.gov.za/speeches/2006/06112910451005.htm

Sitios de la Comisión por la Memoria y Museo de Arte y Memoria de la Provincia de Buenos Aires: http://www.comisionporlamemoria.org/museodearteymemoria/inicio.php 